ALINE MAIA DANTAS

\title{
ESTUDO DA RELAÇÃO ENTRE GLÂNDULAS SALIVARES \\ E DOENÇA PERIODONTAL EM RATOS
}

Tese apresentada ao Programa de PósGraduação em Farmacologia do Instituto de Ciências Biomédicas da Universidade de São Paulo, para obtenção do Título de Doutor em Ciências. 


\section{ALINE MAIA DANTAS}

Estudo da relação entre glândulas salivares e doença periodontal em ratos

Tese apresentada ao Programa de PósGraduação em Farmacologia do Instituto de Ciências Biomédicas da Universidade de São Paulo, para obtenção do Título de Doutor em Ciências.

Área de concentração: Farmacologia

Orientador: Prof. Dr. Marcelo N. Muscará

Versão corrigida: A versão original está disponível na secretaria de comunicação do ICB. 
DADOS DE CATALOGAÇÃO NA PUBLICAÇÃO (CIP)

Serviço de Biblioteca e Informação Biomédica do Instituto de Ciências Biomédicas da Universidade de São Paulo

reprodução não autorizada pelo autor

Maia-Dantas, Aline.

Estudo da relação entre glândulas salivares e doença periodontal em ratos / Aline Maia-Dantas. -- São Paulo, 2011.

Orientador: Marcelo Nicolas Muscará.

Tese (Doutorado) - Universidade de São Paulo. Instituto de Ciências Biomédicas. Departamento de Farmacologia. Área de concentração: Farmacologia. Linha de pesquisa: Doença periodontal experimental.

Versão do título para o inglês: Study on the relationship between salivary glands and periodontal disease in rats.

Descritores: 1. Periodontite 2. Glândulas salivares 3. Saliva I. Muscará, Marcelo Nicolas II. Universidade de São Paulo. Instituto de Ciências Biomédicas. Programa de Pós-Graduação em Farmacologia III. Título. 
UNIVERSIDADE DE SÃO PAULO

INSTITUTO DE CIÊNCIAS BIOMÉDICAS

\begin{abstract}
Candidato(a):
Aline Maia-Dantas.

Título da Tese:

.Estudo da relação entre glândulas salivares e doença periodontal em ratos.
\end{abstract}

Orientador(a): $\quad$ Marcelo Nicolas Muscará.

A Comissão Julgadora dos trabalhos de Defesa da Tese de Doutorado, em sessão pública realizada a ..................., considerou

\title{
( ) Aprovado(a) \\ ( ) Reprovado(a)
}

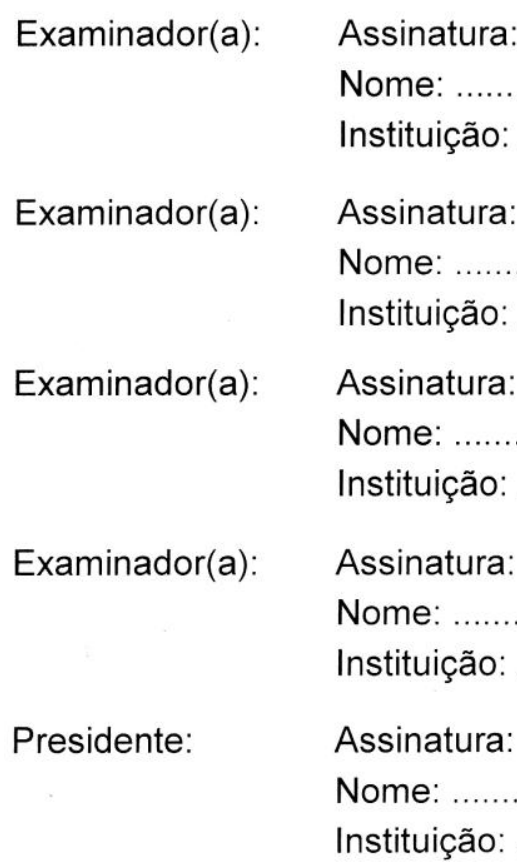




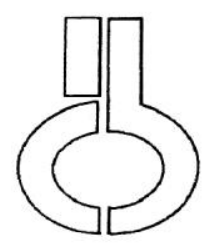

\section{Certificado}

Certificamos que o protocolo registrado sob $n^{\circ} 020$ nas fls. 29 do livro 2 para uso de animais em experimentação, sob a responsabilidade do(a) Prof.(a) Dr.(a) Marcelo Nicolas Muscará, Coordenador(a) da Linha de Pesquisa "Estudo da relação entre glândula salivares e doerşa periodontal em ratos: participação do óxido nitrico e espécies relacionadas" do qual participou(aram) o(s) alunos Aline Maia Dantas, Paula Campi Locatelli de Almeida, Rodrigo Martins Porto, Bruno Schneider Herrera, Ana Alice dos Santos Dias, Alexandre Denadai Souza, Ana Augusta Varriano, Simone Marques Bolonnbeis, Carly de Faria Ccalho, Cristian César Carrari, Lidia Mitiko Yshii, Livia de Lucca Camargo, Juliano Fernandes de Oliveira, Juliana Florenzano, Mônica Coutinho Dantas, Ligia de Cássia Val está de acordo com os Princípios Éticos de Experimentação Animal adotado pelo Colégio Brasileiro de Experimentação ínimal (COREA) e foi aprovado pela COMISSÃO DE ÉTICA EM EXPERIMENTAÇĀO ANIMAL (CEEA) em 23.02.2006.

São Paulo, 06 de março de 2006.

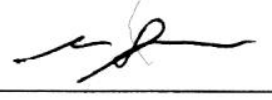

Profa. Dra. Marília C.L.Seelaender Coordenadora -CEEA - ICB/USP

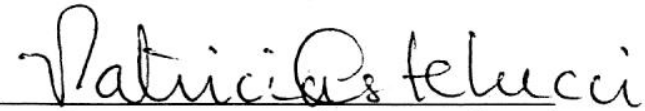

Profa. Dra. Patricia Castelucci Secretária Suplente CEEA - ICB/USP 
Aos meus pais e irmão pelo

Incentivo, apoio e participação ativa

em minha formação.

Obrigada! 


\section{AGRADECIMENTOS}

Aos alunos do Laboratório de Farmacologia Bioquímica dos Radicais Livres pelo inestimável auxílio e convivência.

À CAPES, agência financiadora de minha bolsa. Ao Santander-Banespa que, ao conceder-me a bolsa Santander-Banespa-USP de Mobilidade Internacional, possibilitou a realização de meu estágio em Buenos Aires, de grande valor para completar minha formação.

Ao CEFyBO- CONICET e a Universidad de Buenos Aires que proveram a estrutura necessária à realização de meu estágio.

Aos amigos e professores pela dedicação, incentivo, convívio e amizade.

Às secretárias: Selma, Julieta e Camila, sempre prontas a auxiliar e ajudar.

À Universidade de São Paulo e toda a estrutura que proporcionou a realização de meus estudos de graduação e pós-graduação, e por ser esse pedacinho de verde no meio de

São Paulo, que muda nosso humor sempre que adentramos seus portões.

Enfim a todos que contribuíram para a realização deste trabalho, seja direta ou indiretamente.

Meu muito obrigada por tudo! 


\section{AGRADECIMENTOS ESPECIAIS}

Ao meu orientador, Prof. Dr. Marcelo Nicolás Muscará pela oportunidade de trabalhar em seu laboratório, pela convivência, por semear em mim o espírito crítico, e pelos muitos ensinamentos.

À Prof. Dra.Soraia Costa, pelos importantes ensinamentos, sugestões e auxílio para elaboração deste trabalho.

À Prof. Dra. Valéria Beshuli Rettori, minha co-orientadora argentina, que me recebeu de portas abertas em seu laboratório, pelos ensinamentos, pela ajuda e preocupação com meu bem -estar em um país estranho.

À Prof. Dra. Simone Aparecida Teixeira, pelos ensinamentos, por sua paciência e boa vontade em ajudar sempre, bem como pelo estímulo nas dificuldades e confiança em nossa capacidade de superá-las.

Ao Prof. Dr. Javier Fernadez-Solari pela ajuda, apoio, risadas, amizade e companhia que tornaram nosso trabalho algo sempre positivo.

Ao Prof. Dr. Juan Carlos Elverdín, com quem trabalhar sempre foi uma prática divertida e educativa.

Aos meus amigos periodontais: Paula Campi Locatelli de Almeida, cuja amizade ultrapassou a graduação, continuando firme ao longo da pós; Rodrigo Martins Porto, por sua sempre presente paciência e amizade e Bruno Shcneider Herrera pelos risos sempre tão necessários e oportunos

Aos meus companheiros de laboratório que fizeram com que os trabalhos fossem mais especiais: Cristiane Ramos, Eduardo Ekundi, Leandro Rodrigues, Marco Aurélio, Juliana Florenzano, Karen Tiago, Carly de Faria Coelho, Simone Bolonheis, Ana Augusta Varriano, Ana Alice dos Santos, Livia de Lucca, Alexandre Denadai, Joyce, Marcelo, Cristian, André, Vivi, Flávia, Enilton. 
Aos companheiros de laboratório de Buenos Aires que me fizeram sentir em casa: Claudia Mohon, Elisa Rettori, Andrea de Laurentiis, Maria Zorilla, Carolina de la Cal, Irene Vacas, Mariano Amer e Juan Pablo Prestifillipo.

E claro, às nossas queridas Irene e D. Alice, técnicas sempre dispostas a nos ajudar e socorrer. 
O saber humano se espalha para todos os lados, a perder de vista, de modo que nenhum indivíduo pode saber se quer a milésima parte daquilo que é digno de ser sabido. 


\section{RESUMO}

MAIA-DANTAS, A. Estudo da relação entre glândulas salivares e doença periodontal em ratos. 2011. 106 f. Tese (Doutorado em Farmacologia) - Instituto de Ciências Biomédicas, Universidade de São Paulo, São Paulo, 2011.

A gengivite e a periodontite constituem doenças periodontais infecciosas comuns do homem, nas quais as bactérias periodontais e seus produtos podem participar ativamente na indução da inflamação local e efeitos sistêmicos (ex.: coração). Sabendo que a saliva representa a primeira e grande barreira às infecções orais, este trabalho se propôs a: i) avaliar a perda óssea induzida pela doença periodontal em ratos submetidos à indução de doença, via implante de ligadura, após os intervalos de 3, 7 e 14 dias; ii) Investigar possíveis alterações de fluxo (estimulado ou não com pilocarpina) e composição salivar nesses animais; iii) avaliar a concentração / expressão de marcadores de estresse oxidativo e inflamatórios em glândulas salivares e em amostras de saliva; iv) avaliar o papel funcional das glândulas salivares ex-vivo na produção da amilase. Para isto, ratos Wistar machos (180 200g) foram submetidos à indução da periodontite através do implante da ligadura, e os parâmetros inflamatórios e bioquímicos foram avaliados nesses animais. Ratos com periodontite no dia 3, quando comparado ao grupo sham, exibiram aumento significativo do fluxo salivar (estimulado com pilocarpina), produção de $\mathrm{Ca}^{2+}$, secreção de proteínas e produção de amilase na saliva, bem como aumento do conteúdo de TBARS em glândulas parótidas e da amilase liberada das glândulas submandibulares (GSM). Observou-se, ainda, aumento da expressão de mRNA para iNOS e nNOS em GSM. Em contrapartida, ratos com periodontite após 7 dias exibiram redução da taxa de salivação estimulada (e não estimulada), da produção de proteínas totais e da concentração e secreção de amilase na saliva, muito embora o conteúdo sérico e salivar de TBARS e da atividade de MPO na saliva desses animais mostrou-se elevado em relação ao grupo sham. Não foram observadas diferenças significativas quanto ao conteúdo de TBARS em glândulas salivares, secreção e concentração de $\mathrm{Ca}^{2+}$ na saliva e tampouco sobre o conteúdo de proteínas nitradas em amostras de GSM desses animais. Já no $14^{\circ}$ dia visualizou-se um aumento da atividade de NOS $\mathrm{Ca}^{2+}$ dependente e da expressão mRNA das iNOS e nNOS em GSM. Ratos com periodontite, após 14 dias de indução, não exibiram aumento significativo na taxa de salivação, concentração e secreção de $\mathrm{Ca}^{2+}$ salivar, produção e concentração de proteínas totais, amilase na saliva e conteúdo de TBARS em amostras de saliva e glândulas salivares. Ainda, observou-se aumento das atividades da peroxidase/MPO, concentração de nitrato em saliva e proteínas nitradas em GSM e maior concentração de citocinas Th1 / Th2 (IL-4, IL13 e IL-10) em amostras de GSM. Conclui-se que a indução experimental da doença periodontal em ratos, influencia o funcionamento de glândulas salivares de acordo com os dias de indução, inicialmente estimulando, em um segundo momento inibindo e posteriormente retornando aos níveis basais. Após 7 dias, caracteriza-se como o tempo ideal para a manifestação dos efeitos inibitórios na glândula.

Palavras-chave: Periodontite. Inflamação. Glândula salivar. Saliva. 


\begin{abstract}
MAIA-DANTAS, A. Study of the relationship between the salivary glands and periodontal disease in rats. 2011.106 p. Ph. D. thesis (Pharmacology) - Instituto de Ciências Biomédicas, Universidade de São Paulo, São Paulo, 2011.
\end{abstract}

Gingivitis and periodontitis are common infectious periodontal diseases in man, in which periodontal bacteria and their products participate actively to induce local inflammation and systemic effects (eg heart). Knowing that saliva represents the first major barrier to oral infections, this study aimed to: i) to assess bone loss due to induced periodontitis in rats, after intervals of 3, 7 and 14 days, ii) to investigate possible changes in flow (or not stimulated with pilocarpine) and salivary composition in these animals, and iii) evaluate the concentration and expression of markers of oxidative stress and inflammation in the salivary glands and saliva samples, and iv) assess the functional role of salivary gland function in ex vivo production of amylase. For this purpose, male Wistar rats (180-200g) underwent induction of periodontitis by implanting the ligature, and biochemical and inflammatory parameters were assessed. Rats with periodontitis on day 3 when compared to sham group, exhibited a significant increase in salivary flow (stimulated with pilocarpine), production of $\mathrm{Ca}^{2+}$, protein secretion and production of amylase in saliva, as well as increased contents of TBARS in the parotid and amylase released from submandibular glands (GSM). There was also increased expression of mRNA for iNOS and nNOS in GSM. In contrast, rats with periodontitis after 7 days exhibited a reduction in stimulated saliva (not stimulated), production and total protein concentration and secretion of salivary amylase, although the content of serum and salivary TBARS and the activity of MPO in saliva of these animals was high compared to the sham group. There were no significant differences in TBARS content in salivary gland secretion and $\mathrm{Ca}^{2+}$ concentration in saliva, nor on the content of nitrated proteins in samples from these animals GSM. By the 14th day envisioned an increase of NOS activity and $\mathrm{Ca}^{2+}$ dependent mRNA expression of iNOS and nNOS in GSM. Rats with periodontitis, 14 days after induction, exhibited a significant increase in the rate of salivation, concentration and salivary secretion of $\mathrm{Ca}^{2+}$, production and concentration of total protein, salivary amylase and content of TBARS in samples of saliva and salivary glands. Still, there was increased activity of peroxidase / MPO, nitrate concentration in saliva and proteins nitrated in GSM and higher concentration of Th1 / Th2 (IL-4, IL-13 and IL-10) in samples of GSM. We conclude that the experimental induction of periodontal disease in rats, influence the functioning of the salivary glands according to the days of induction, initially stimulating, in a second time and subsequently inhibiting return to baseline levels. After 7 days, is characterized as the ideal time for the expression of an inhibitory effect on the gland function.

Key words: Periodontitis. Inflammation. Salivary glands. Saliva. 


\section{LISTA DE FIGURAS}

Figura 1.Película radiográfica e os pontos de análise utilizados

Figura 2. Análise da perda óssea alveolar.

Figura 3. Análise do fluxo salivar não estimulado ou estimulado.

Figura 4. Medida da concentração e secreção de cálcio salivar.

Figura 5. Concentração e taxa de secreção protéica salivares.

Figura 6. Proteinograma eletroforético de amostras de saliva

56

Figura 7. Proteinograma eletroforético de amostras de saliva

Figura 8. Proteinograma eletroforético de amostras de saliva.

Figura 9. Mensuração salivar de amilase.

Figura 10. Mensuração salivar de amilase

Figura 11. Mensuração salivar de amilase

Figura 12. Determinação do conteúdo tecidual de produtos de reação do ácido tiobarbitúrico em amostras de 3 dias.

Figura 13. Determinação do conteúdo tecidual de produtos de reação do ácido tiobarbitúrico em amostras de 7 dias.

Figura 14. Determinação do conteúdo $d$ tecidual de produtos de reação do ácido tiobarbitúrico em amostras de 14 dias.

Figura 15. Concentração de íons nitritos+nitratos $\left(\mathrm{NO}_{\mathrm{x}}{ }^{-}\right)$em amostras de saliva.

Figura 16. Determinação da atividade de MPO/ peroxidase salivar 
Figura 17. Determinação da atividade de MPO/ peroxidase salivar.

Figura 18. Determinação da atividade de MPO/ peroxidase salivar.

Figura 19. Análise de resíduos protéicos de nitrotirosina, detectados por slot blot presentes em glândula submandibular

Figura 20. Análise de resíduos protéicos de nitrotirosina, detectados por slot blot presentes em glândula submandibular.

Figura 21. Análise de resíduos protéicos de nitrotirosina, detectados por slot 76 blot presentes em glândula submandibular

Figura 22. Medida da concentração de amilase liberada por GSM exvivo

Figura 23. Medida da atividade de óxido nítrico sintase em glândula submandibular (GSM)

Figura 24. Medida da atividade de óxido nítrico sintase em glândula parótida.

Figura 25. Análise de PCR quantitativo para as diferentes isoformas de NOS em 87 glândula submandibular (GSM)

Figura 26. Análise de PCR quantitativo para as diferentes isoformas de NOS em 88 glândula submandibular (GSM).

Figura 27. Análise de PCR quantitativo para as diferentes isoformas de NOS em 89 glândula submandibular (GSM). 


\section{LISTA DE TABELAS}

Tabela 1- Desenho dos primers utilizados para realização da PCR...................... 47

Tabela 2- Análise das citocinas encontradas em glândulas -3 dias......................... 80

Tabela 3- Análise das citocinas encontradas em glândulas -7 dias........................ $\quad 80$

Tabela 4- Análise das citocinas encontradas em glândulas -14 dias....................... 81 


\section{LISTA DE REAGENTES}

\section{Nome}

Trizol

Tween-20

Marcadores protéicos de peso molecular

Clorofórmio

Álcool isoamílico

Álcool isopropílico

Álcool etílico

Tampão Tris Acetato EDTA

Agarose

Brometo de etídio

DTT

Inibidor de RNAses

$\mathrm{RT}$ - transcriptase reversa

RNAse $\mathrm{H}$

5x First Strand Buffer

dNTPs mix

PCR buffer

\section{Procedência}

GIBCO BRL, EUA

Sigma Chemical Co., St. Louis, EUA

MultiMark Multi-Colored Standard;

Invitrogen, Califórnia, EUA

Mallinckrodt, França

Mallinckrodt, França

Mallinckrodt, França

J.T. Baker, México

GIBCO BRL, EUA

GIBCO BRL, EUA

GIBCO BRL, EUA

Invitrogen, EUA

GIBCO BRL, EUA

USB . Inglaterra

USB . Inglaterra

USB . Inglaterra

Invitrogen, EUA

Biotools, Brasil 
$\mathrm{MgCl}_{2}$

Taq polimerase

Acrilamida PAGE

Bisacrilamida

Glicerol 87\% w/w

Tris Base

Dodecil sulfato de sódio

Persulfato de sódio

Temed

Glicina

Cloreto de sódio

Azul de bromofenol

Caseína

Fluoreto de fenil metil sulfonila (PMSF)

Ditiotreitol (DTT)

Reagente Comassie Brilliant Blue

Kit de Quimioluminescência

Beta-mercapto etanol

Anticorpo anti-nitrotirosina monoclonal (camundongo)

Ácido acético glacial
Biotools, Brasil

Biotools, Brasil

Pharmacia Biotech, Uppsala, Suíça

Pharmacia Biotech, Uppsala, Suíça

Pharmacia Biotech, Uppsala, Suíça

Sigma Chemical Co., St. Louis, EUA

USB, Ohio, EUA

Life Technologies, California, EUA

Pharmacia Biotech, Uppsala, Suíça

Pharmacia Biotech, Uppsala, Suíça

Mallinckrodt Baker, Mexico D.F., Mexico

Sigma Chemical Co., St. Louis, EUA

Sigma Chemical Co., St. Louis, EUA

Sigma Chemical Co., St. Louis, EUA

Sigma Chemical Co., St. Louis, EUA

Bio-Rad, Califórnia, EUA

Bio-Rad, California, EUA

Sigma Chemical Co., St. Louis, EUA

Upstate Lab., Nova York, EUA

Mallinckrodt Baker, Mexico D.F., Mexico 
Anticorpo anti-lg de camundongo (coelho) Bio-Rad, Califórnia, EUA conjugado com fosfatase alcalina

Cloridrato de pilocarpina $4 \%$ Allergan $^{\circledR}$, Brasil 


\section{LISTA DE ABREVIATURAS}

\begin{tabular}{|c|c|}
\hline Abreviatura & Nome \\
\hline iNOS & Óxido nítrico sintase induzível \\
\hline eNOS & Óxido nítrico sintase endotelial \\
\hline nNOs & Óxido nítrico sintase neuronal \\
\hline NOS & Óxido nítrico sintase \\
\hline $\mathrm{Ca}^{+2}$ & Íon cálcio \\
\hline CaM & Calmodulina \\
\hline CEEA & Comissão de Ética em Experimentação Animal \\
\hline $\operatorname{cox}$ & Ciclooxigenase \\
\hline DAG & Diacilglicerol \\
\hline GSM & Glândula Submandibular \\
\hline $\mathrm{H}_{2} \mathrm{O}_{2}$ & Peróxido de hidrogênio \\
\hline HPA & Eixo hipotalâmico-pituitária-adrenal \\
\hline HTAB & Brometo de hexadeciltrimetilamôneo \\
\hline ICAM-1 & Molécula de adesão intercelular tipo 1 \\
\hline IFN $\gamma$ & Interferon $\gamma$ \\
\hline IL-1 $1 \beta$ & Interleucina $1 \beta$ \\
\hline IL-2 & Interleucina 2 \\
\hline IL-3 & Interleucina 3 \\
\hline IL-4 & Interleucina 4 \\
\hline IL-5 & Interleucina 5 \\
\hline IL-6 & Interleucina 6 \\
\hline IL-10 & Interleucina 10 \\
\hline IL-13 & Interleucina 13 \\
\hline i.p & Intraperitoneal \\
\hline $\mathrm{IP}_{3}$ & Inositol $1,4,5$ trifosfato \\
\hline JEC & Junção Esmalte-Cemento \\
\hline L-arg & L- arginina \\
\hline L-cit & L-citrulina \\
\hline LPS & Lipopolissacarídeo \\
\hline MDA & Malondialdeído \\
\hline MMP & Metaloproteinases \\
\hline
\end{tabular}




$\begin{array}{ll}\text { MPO } & \text { Mieloperoxidase } \\ \text { NO } & \text { Óxido nítrico } \\ 3-N T & \text { 3- nitrotirosina } \\ \mathrm{ONOO}^{-} & \text {Ânion peroxinitrito } \\ \mathrm{O}_{2}^{\bullet-} & \text { Radical ânion superóxido } \\ \mathrm{OH}^{\bullet} & \text { Radical hidroxila } \\ \text { PG } & \text { Prostaglandina } \\ \text { PGE2 } & \text { Prostaglandina E2 } \\ \text { PMN } & \text { Polimorfonuclear } \\ \text { Pe } & \text { Periodontite } \\ \text { RYR } & \text { Receptor de rianodina } \\ \text { ROS } & \text { Espécies reativas de oxigênio } \\ \text { SH } & \text { Sham } \\ \text { SOD } & \text { Superóxido dismutase } \\ \text { TBA } & \text { Ácido tiobarbitúrico } \\ \text { TBARS } & \text { Espécies reativas do ácido tiobarbitúrico } \\ \text { TIMP } & \text { Inibidor tecidual de Metaloproteinases } \\ \text { TNFa } & \text { Fator de necrose tumoral } \\ \text { U.A. } & \text { Unidades Arbitrárias } \\ \text { TBS-t } & \text { Tris Buffered Saline -Tween }\end{array}$




\section{SUMÁRIO}

1 INTRODUÇÃO

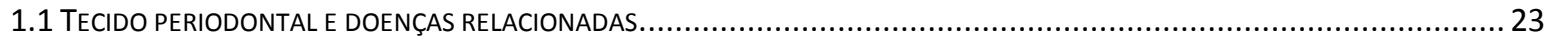

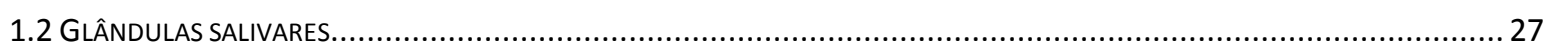

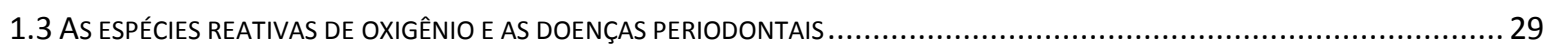

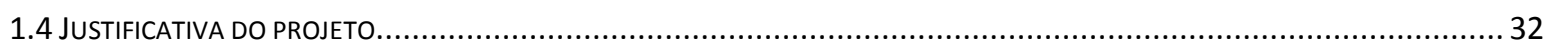

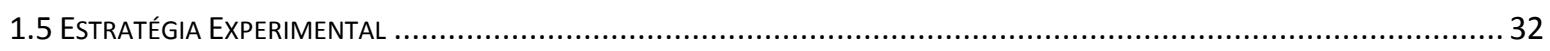

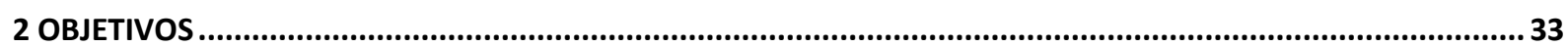

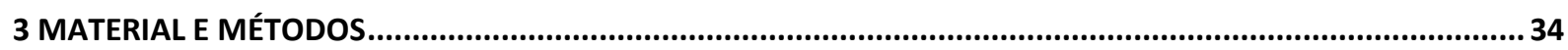

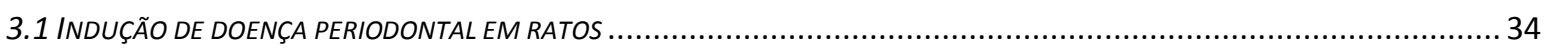

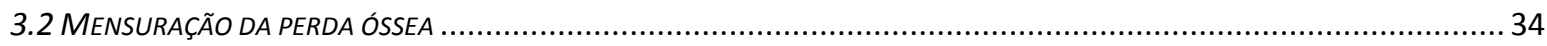

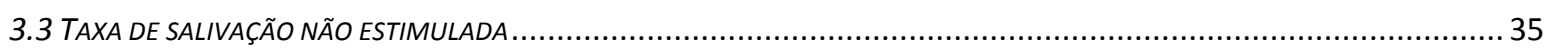

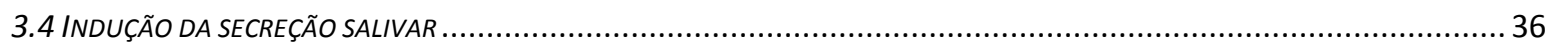

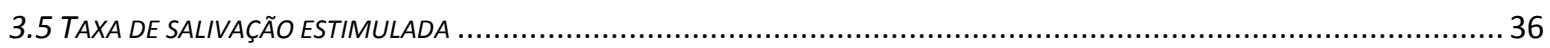





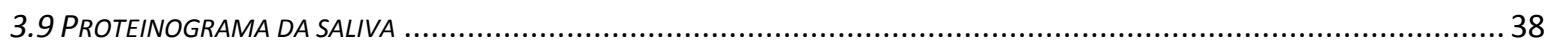

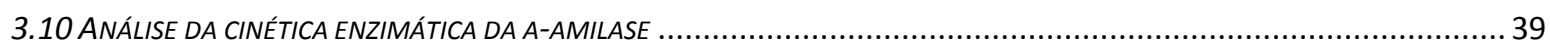

3.11 DETERMINAÇÃO DO CONTEÚDO TECIDUAL DE PRODUTOS DE REAÇÃO DO ÁCIDO TIOBARBITÚRICO (TBARS).......... 39

3.12 DETERMINAÇÃO DAS CONCENTRAÇÕES SALIVARES TOTAIS DE NITRATO + NITRITO (NO $))$ PELO MÉTODO DE GRIESS..... 40

3.13 MEDIDA DA ATIVIDADE TECIDUAL E SALIVAR DE MIELOPEROXIDASE (MPO) E PEROXIDASE ....................................... 41

3.14 ANÁLISE DA EXPRESSÃO DE RESÍDUOS PROTÉICOS DE NITROTIROSINA (NT) .................................................. 42

3.15 ATIVIDADE FUNCIONAL "EX VIVO” DE GLÂNDULAS SUBMANDIBULARES E SUBLINGUAIS" ........................................... 43

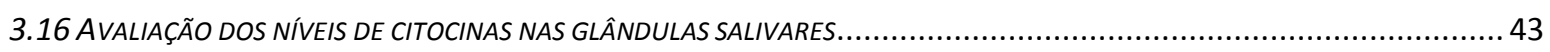

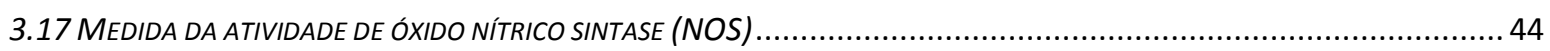

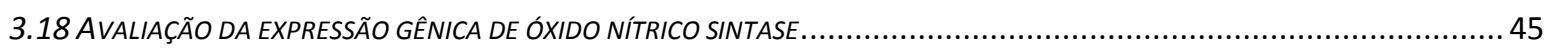

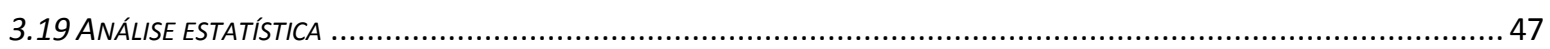

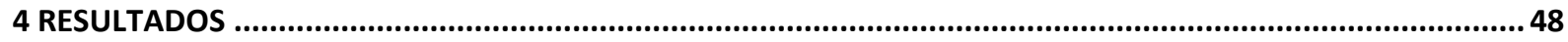

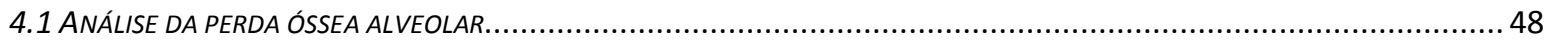

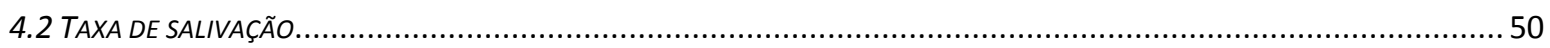

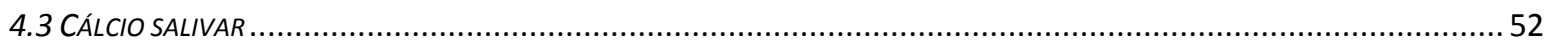

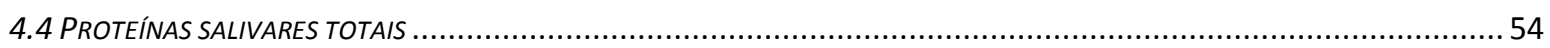

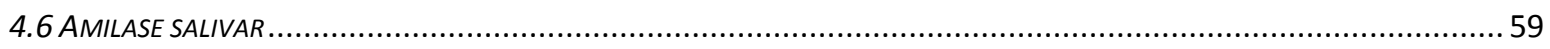

4.7 DETERMINAÇÃO DO CONTEÚDO TECIDUAL DE PRODUTOS DE REAÇÃO DO ÁCIDO TIOBARBITÚRICO (TBARS)................. 63

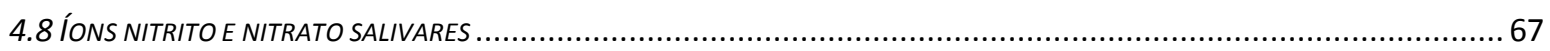

4.9 MEDIDA DA ATIVIDADE TECIDUAL E SALIVAR DE MIELOPEROXIDASE (MPO) E PEROXIDASE ....................................69

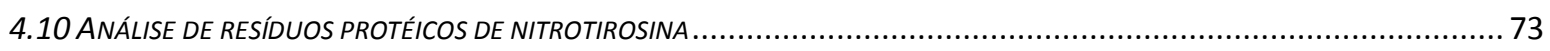

4.11 ATIVIDADE FUNCIONAL “EX VIVO” DE GLÂNDULAS SUBMANDIBULARES E SUBLINGUAIS.........................................77

4.12 DOSAGEM DE CITOCINAS EM AMOSTRAS DE GLÂNDULAS SUBMANDIBULARES (GSM) .............................................

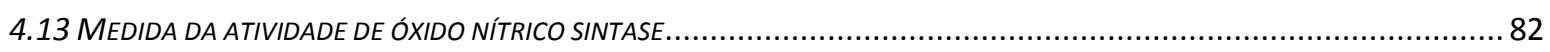



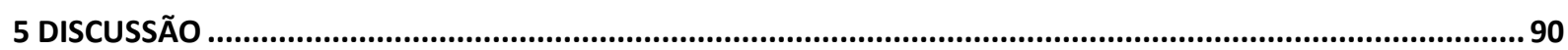




\section{CONCLUSÃO}




\section{INTRODUÇÃO}

\subsection{Tecido periodontal e doenças relacionadas}

A cavidade bucal constitui uma das primeiras portas de entrada para microorganismos presentes no ar e nos fluidos (em especial a saliva) de outros indivíduos, e que podem ter efeitos devastadores sobre o organismo, caso consigam penetrá-lo (Tlaskalova-Hogenova et al., 2002). Além de apresentar papel protetor sobre as infecções (Tlaskalova-Hogenova et al., 2002), a saliva possui importante participação na digestão, secreção de enzimas (em particular, a amilase), sensibilidade gustativa, além de auxiliar na deglutição dos alimentos e contribuir para a manutenção da integridade dos dentes. Desta feita, as secreções salivares mantêm os tecidos bucais em estado de equilíbrio (Pedersen et al., 2002).

Na cavidade bucal está presente o periodonto, um tecido complexo que compreende o osso alveolar, ligamento periodontal, cemento e gengiva. Por conta da complexidade desse tecido, inúmeros mediadores endógenos são gerados por células residentes, que incluem fibroblastos e leucócitos polimorfonucleares, que muitas vezes desempenham papéis ambíguos quanto à manutenção da integridade tecidual (Dixon et al., 2004; Liu et al., 2010). Dentre as funções principais do periodonto, destaca-se a união dos elementos dentários aos ossos maxilares e mandibulares, a qual garante, via fibras do ligamento periodontal, que cargas oriundas do ato da mastigação não sejam transmitidas diretamente aos ossos. Tal controle é exercido por mecanorreceptores presentes na região (Trulsson, 2006).

Por seu turno, a placa bacteriana é o fator determinante das doenças periodontais. Inicia-se a partir da maturação do biofilme dental, uma fina película que se deposita diretamente sobre a superfície dos dentes, dos materiais restauradores e do epitélio bucal, formada por componentes secretados pelas glândulas salivares, por restos de alimento e por células epiteliais descamadas (De Lorenzo, 2004).

No início desse processo, algumas bactérias, auxiliadas por adesinas localizadas na superfície de fímbrias e fibrilas, se aderem às glicoproteínas encontradas na película adquirida (Rickard et al., 2003), permitindo que outras bactérias possam ligar-se 
seletivamente às pioneiras, acumulando-se gradativamente e amadurecendo o biofilme dental (De Lorenzo, 2004).

As doenças periodontais podem restringir-se aos tecidos de proteção do dente, a chamada gengivite, ou ainda, podem estender-se aos tecidos de suporte do dente, resultando na periodontite (Armitage et al., 1999; Page, 1991). Em geral, isto ocorre devido ao reflexo da mudança na microbiota da placa. Assim, na gengivite, ocorre um aumento do número de bactérias, que parte de $10^{2}-10^{3}$ na condição saudável, para $10^{4}-10^{6}$ na gengivite, enquanto na periodontite, esse número varia de $10^{5}-10^{8}$. A composição da placa sofre alteração de acordo com seu estado. Desta feita, enquanto no estado saudável verifica-se na placa, aproximadamente, $15 \%$ de contaminação por bactérias Gram negativas, na vigência da doença periodontal, essas espécies compreendem 50\% da composição da placa (Tanner, 1998; Socransky, 2008).

A resposta do hospedeiro frente às bactérias é essencialmente de proteção, muito embora a intensificação dessa resposta possa levar à destruição tecidual, evidenciando o papel fundamental de características individuais no desenvolvimento da doença periodontal (Socransky e Haffajee, 1994; Kornman et al., 1997; Carranza e Newman, 2002). Em parte, acredita-se que essa resposta é também determinada por predisposição genética, apesar de fatores adquiridos e ambientais, tais como o uso do cigarro e o abuso do álcool, influenciarem grandemente na progressão da doença (Page, 1999; Johnson e Slach, 2001; Linden et al., 1996; Mealey et al., 2000; Hergstrom et al., 2004; Heitz-Mayfield et al., 2005; Heasman, 2006; Timmerman, 2006).

As doenças periodontais estão entre as doenças crônicas mais prevalentes em humanos. Essas doenças podem acometer tecidos de suporte e proteção dos dentes (Ford et al., 2010; Liu et al., 2010)., No Brasil, estima-se que $85 \%$ da população adulta, com idade entre 35 e 40 anos, residentes em zonas urbanas apresentam algum tipo de doença periodontal (Pinto et al., 1999; Brasil, 2005). Nesses indivíduos, as doenças periodontais, em diferentes graus, são responsáveis pela maior parte das perdas dentárias (Brown e Loe, 1993; Tinoco et al., 1997; Albandar e Rams, 2002).

As periodontopatias não possuem fases inflamatórias agudas e crônicas muito definidas, muitas vezes descritas como lesões crônicas, devido ao tempo que demoram para produzir destruição. Morfologicamente, essas doenças exibem componentes inflamatórios crônicos e agudos que se sobrepõem (Page e Schoreder, 1976). No entanto, a análise desses 
tecidos permite estabelecer, de acordo com os tipos celulares predominantes e do tipo de dano tecidual apresentado, o grau de progressão da doença; permitindo-nos classificá-la em lesão gengival inicial, precoce, estabelecida ou avançada (Page e Schoreder, 1976). O cálculo periodontal, vulgarmente conhecido como tártaro, é elemento característico da doença periodontal. Este é formado graças à mineralização da placa, pela absorção de íons cálcio e fosfato presentes na saliva e no fluido crevicular (Jin et al., 2002).

A lesão gengival inicial se dá após 24 horas de formação de placa, podendo ser caracterizada pelo aumento da permeabilidade vascular e presença de células polimorfonucleares (PMN). Adiante, após 7 dias de formação da placa, origina-se a lesão precoce, cuja característica morfológica predominante inclui, angiogênese (aumento da vascularização local), presença de linfócitos, PMN e destruição de fibroblastos e colágeno. A lesão estabelecida, que ocorre entre 3 e 4 semanas após a formação de placa, é clinicamente conhecida como gengivite. Nesse caso, detecta-se perda significativa de elementos celulares e constituintes anatômicos de uma gengiva normal. Adicionalmente, a inflamação não se estende aos elementos de suporte do dente e o Infiltrado inflamatório corresponde a 10$30 \%$ do tecido conjuntivo. A lesão avançada (periodontite) caracteriza-se por uma maior expansão do infiltrado de células inflamatórias, gerando um aprofundamento da bolsa. Isto está associado à uma perda substancial de osso alveolar, dano extenso às fibras, migração apical do epitélio juncional, manifestações disseminadas de danos inflamatórios e imunopatológicos aos tecidos. Há ainda forte predomínio de plasmócitos (Page e Schoreder, 1976; Zappa, 1995).

Conforme as respostas do sistema imunológico, a patogenia da doença periodontal, pode ser dividida em quatro estágios distintos: i) inicialmente, o epitélio de união secreta mediadores inflamatórios, tais como citocinas/quimiocinas (IL-8, TNF- $\alpha, \mathrm{IL}-1 \alpha)$, prostaglandinas $\left(\mathrm{PGE}_{2}\right)$ e metaloproteinases $(\mathrm{MMP})$ e ocorre também a liberação de neuropeptídeos e de histamina; ii) inicia-se, a seguir, formação da resposta inflamatória local, além de ativação de proteínas séricas, como aquelas liberadas pelo sistema complemento; iii) adiante, inicia-se o influxo do infiltrado de células, com predomínio de células mononucleares, linfócitos e plasmócitos, e o extravasamento de fluidos inflamatórios e, por fim iv) ocorre a ativação das células T, que irão produzir subsequentemente diversas citocinas e quimiocinas (IL-2, 3, 4, 5, 6, IL-10, IL-13 TNF- $\alpha$, TGF- $\beta$, IFN- $\gamma$ ) envolvidas na resposta imunológica. Além disto, os leucócitos liberados podem secretar citocinas e 
leucotrienos, enquanto os fibroblastos ativados produzem metaloproteinases (MMP) e inibidores teciduais de metaloproteinases (TIMP).

Estabelecido o processo inflamatório crônico, observam-se alterações teciduais, que podem levar à perda de função e alteração na homeostasia tecidual, que leva à degradação do colágeno, da matriz óssea e, por conseguinte, evolui para a periodontite (Kornman et al., 1997; Ford et al., 2010; Liu et al., 2010). Cabe ressaltar que a magnitude da resposta inflamatória é crucial para determinar a severidade e duração da doença, podendo esta gerar destruição tecidual severa, capaz de acarretar a perda do elemento dental (Lundy et al., 2004).

Uma vez afetados, os tecidos de suporte do dente não se regeneram, apresentando-se como única alternativa o controle da doença, na tentativa de conter sua expansão e manter o elemento dental na cavidade (Kinane et al., 2008). Além da perda dentária, alguns estudos demonstram que as bactérias periodontais e seus produtos afetam, além da cavidade bucal, outros órgãos e sistemas (Beck et al., 1996; Beck et al., 2000; Noack et al., 2001; Seymour et al., 2003; D'Aiuto et al., 2004; Meurman et al., 2004; Vettore et al., 2008; Buhlin et al., 2009; de Pablo et al., 2009).

Os efeitos sistêmicos parecem decorrer da exposição contínua dos portadores da doença às bactérias e seus produtos, visto que tais pacientes exibem o epitélio ulcerado da bolsa formada pela doença periodontal. Assim, esses pacientes ficam mais vulneráveis e a circulação sangüínea torna-se um alvo para disseminação sistêmica destas (Beck et al., 2000). É interessante acrescentar que elevadas concentrações de proteína C reativa (CRP) foram encontradas no plasma de indivíduos com doença periodontal, semelhantes as encontradas em pacientes com cardiopatias (Beck et al., 1996; Noack et al., 2001; D'Aiuto et al., 2004; Meurman et al., 2004).

A associação entre as doenças cardíacas ou renais com as doenças periodontais vem sendo bastante discutida (Beck et al., 2000; Seymour et al., 2003 ; Buhlin et al., 2009; de Pablo et al., 2009; Vettore et al., 2008, Herrera 2011). Ademais, a ocorrência de parto prematuro vem sendo atribuído à mulheres com doenças periodontais. Nesse caso, acreditase que lipopolissacarídeos (LPS) da membrana de bactérias Gram negativas presentes na cavidade bucal destas, estimulam a produção de IL-1ß e PGE 2 que, por seu turno, causam contração uterina, acelerando assim o trabalho de parto (Vettore, 2008). 


\subsection{Glândulas salivares}

As glândulas salivares maiores (parótidas, submandibulares e sublinguais) e menores são as responsáveis pela produção da saliva na cavidade bucal, enquanto as glândulas serosas parotídeas produzem um fluído fino, rico em água e amilase quando estimulado, o qual contribui com mais da metade do volume salivar. Quando não se encontram estimuladas, sua contribuição se reduz, e a saliva de origem submandibular passa a ser a maior, em quantidade. Em comparação com a secreção parotídea, a secreção submandibular é mais viscosa e rica em mucina (Pedersen et al., 2002; Almståhl et al., 2001).

A atividade das glândulas salivares é controlada por impulsos nervosos que chegam através de nervos secretores motores pós-ganglionares simpáticos e parassimpáticos, que liberam noradrenalina e acetilcolina, respectivamente, que irão ativar seus respectivos receptores adrenérgicos e muscarínicos, situados na membrana basolateral das células epiteliais. O reflexo para secreção salivar é mediado pelos quimiorreceptores dos botões gustativos e pelos mecanorreceptores do ligamento periodontal que levam à despolarização das fibras nervosas aferentes com o conseqüente aumento do fluxo salivar (Katchburian e Arana, 2004).

Os receptores muscarínicos (M3 e M1) e $\alpha$-adrenérgicos ( $\alpha 2$ ) compreendem receptores metabotrópicos acoplados à proteínas $G$ do tipo $G_{q / 11}$. Assim, a estimulação do receptor leva à hidrólise do fosfatidilinositol 4,5 bifosfato $\left(\mathrm{PIP}_{2}\right)$ via ativação da fosfolipase $C$ (PKC), formando o segundo mensageiro inositol 1,4,5-trifosfato $\left(\mathrm{IP}_{3}\right)$ e diacilglicerol (DAG). $\mathrm{IP}_{3}$ liga-se ao seu receptor no retículo endoplasmático (ER), induzindo um aumento na concentração intracelular de cálcio. Paralelamente, outros envolvidos na secreção salivar são os receptores $\beta$ adrenérgicos, ligados à proteína $G_{s}$ que por sua vez ativa adenilato ciclase e aumenta as concentrações intracelulares de AMPc, promovendo a exocitose através da fosforilação protéica mediada por proteína quinase A (PKA). (Looms et al., 2002).

No que tange ao conteúdo salivar, evidências mostram a presença de células provenientes da descamação do epitélio bucal, bem como componentes provenientes do fluido crevicular (Katchburian e Arana, 2004), fatores inorgânicos (tais como bicarbonato, sódio, potássio, fosfato, fluoreto, amônia e dióxido de carbono) e orgânicos (lisozima, lactoperoxidase, mieloperoxidase e aglutininas, como glicoproteínas, mucinas, fibronectinas, 
macroglobulinas e anticorpos antibacterianos, antifúngicos, hemostáticos, fatores de crescimento, como o fator de crescimento epidermal e importantes imunoglobulinas como as imunoglobulinas A e E (Amerogen et al., 2002)). Ainda, foram identificados na saliva concentrações de enzimas e peptídeos que desempenham importante papel na manutenção da homeostase bucal e de antioxidantes como a superóxido dismutase (SOD), a peroxidase e o ácido úrico, que combatem os radicais livres (Nagler et al., 2002).

Além da manutenção da saúde bucal, as glândulas salivares secretam peptídeos que influenciam na saúde sistêmica do indivíduo (Mathison, 1994), uma vez que eles modulam processos inflamatórios induzidos sistemicamente por LPS ou ovoalbumina (Mathison et al., 1997a, 1997b, 2001; Rougeot et al., 2000; Dery, 2001; Fialho de Araújo et al., 2002 ). Até o presente momento, pelo menos 27 peptídeos biologicamente ativos (incluindo calicreína, fator de crescimento nervoso e fator de crescimento epidermal) foram identificados na saliva, e conhecidamente podem atuar como agentes imunossupressores ou imunoestimuladores (Barka, 1980; Amerogen et al., 2002).Ademais, os peptídeos salivares como, por exemplo a proteína rica em prolina, via sítios específicos de adesão presentes em bactérias relacionadas à enfermidade periodontal, ligam-se à elas, as quais inicialmente se agregarão ao biofilme (Arnold et al., 1977; Gibbons e Hay, 1988; Gibbons, 1994; Leung et al., 1990; Alugupalli et al., 1995; Amano et al., 1996; Johansson et al., 2000; Ayad, 2000; Li et al., 2001).

Assim, os peptídeos salivares, além de atuar na composição da película, regulam a mineralização da mesma, pois favorecem a manutenção adequada da homeostase de cálcio, evitando que ocorra o depósito de cristais de cálcio sobre os dentes, viabilizando a manutenção da saúde periodontal, já que as rugosidades na superfície dental, decorrentes da presença do cálculo, facilitam o depósito de microorganismos maléficos ao periodonto, além de dificultar a adequada higienização (Jin et al., 2002).

Em contrapartida, os efeitos da diminuição da secreção salivar estão associados aos problemas de deglutição, dificuldades na fala, presença de cáries rampantes, presença de úlceras aftosas e, principalmente, à maior prevalência de doenças periodontais em indivíduos com xerostomia (Shiboski, 2007). 
1.3 As espécies reativas de oxigênio e as doenças periodontais

As doenças periodontais geram inúmeros mecanismos de defesa, na tentativa de erradicar os agentes patógenos do organismo, que acabam culminando no aumento de espécies reativas de oxigênio.

Espécies reativas de oxigênio são moléculas muito reativas geradas de maneira natural, decorrente do metabolismo, e que, quando produzidas em excesso, podem gerar lesão e morte celular (Augusto, 2006). Dentre as espécies reativas, destacam-se o radical hidroxila e o ânion superóxido, capazes de oxidar proteínas, ácidos nucléicos e lipídeos, danificando membranas e alterando funções celulares (Halliwell e Gutteridge, 2007).

O óxido nítrico é um gás altamente difundível, sintetizado a partir da conversão do aminoácido L-arginina em L-citrulina, através da ação da enzima óxido nítrico sintase (NOS) (Palmer, 1988).

Sua importância em glândulas salivares deve-se ao fato de que uma das vias de produção salivar é regulada pela acetilcolina (ACh) o que gera um aumento de cálcio intracelular, levando à secreção de água, proteínas e eletrólitos (Looms et al., 2002). O óxido nítrico, tanto endógeno como exógeno, é um importante regulador desse mecanismo de secreção, produzindo um aumento de cálcio intracelular que estimula a liberação salivar (Looms et al., 2002)

É importante também porque dentre os componentes presentes na saliva, destacamse os nitritos, encontrados em grandes quantidades. Esses são gerados a partir de duas vias principais: a redução dos nitratos da dieta por bactérias nitrato redutase positivas ou pela oxidação do óxido nítrico (NO; Grisham et al., 1995; Carrosa et al., 2001). Estudos in vitro demonstram que o íon nitrito presente na saliva, em condições onde o pH mostrou-se ácido, afetou o crescimento e a sobrevivência de bactérias periodontais, sugerindo que o mesmo possa ocorrer in vivo (Allaker et al., 2001).

Há três isoformas de NOS (Bredt et al, 1991). A NOS neuronal (nNOS), presente em vários tipos celulares, fornece NO para processos de neurotransmissão e neuromodulação centrais e periféricos, modula transmissão de impulsos nervosos, e facilita a liberação de neurotransmissores e hormônios (Shibuki, 1990; Dawson, 1994). A NOS endotelial (eNOS), regula o tônus vascular basal, fluxo sanguíneo, inibe a adesão e agregação plaquetárias. Há 
também a isoforma induzível (iNOS), presente em vários tipos celulares em condições patológicas, como macrófagos, hepatócitos, células epiteliais, células endoteliais. Sua transcrição gênica é induzida por LPS bacterianos e citocinas, tais quais, TNF- $\alpha$, IL-1 $1 \beta$, IL-6 e IFN- $\gamma$. A iNOS sintetiza grandes quantidades de NO por longos períodos de tempos e tem não apenas função citotóxica contra microorganismos e células tumorais, mas também participaria nos processos patológicos de vasodilatação e dano tissular (Barreto, 2005).

O NO pode atuar através da ativação da guanilato ciclase solúvel liberando diversas proteino-cinases (sGC; Greengard, 1975); da interação com metalo-proteínas e com moléculas possuidoras de resíduos tióis (Hibbs, 1991; Vallance e Leiper, 2002); e da ativação de canais de potássio dependentes de $\mathrm{Ca}^{2+}$ (Kitamura, 1993).

O NO reage com o oxigênio molecular, formando dióxido de nitrogênio $\left(\mathrm{NO}_{2}\right)$, que pode reagir com outra molécula de $\mathrm{NO}$ e produzir trióxido de dinitrogênio $\left(\mathrm{N}_{2} \mathrm{O}_{3}\right)$ ou com o próprio $\mathrm{NO}_{2}$, gerando tetróxido de dinitrogênio $\left(\mathrm{N}_{2} \mathrm{O}_{4}\right)$, após dismutação geram íons nitrito e nitrato em soluções aquosas (Feelich, 1993, Barreto, 2005). Tanto o $\mathrm{N}_{2} \mathrm{O}_{3}$ como o $\mathrm{N}_{2} \mathrm{O}_{4}$ são considerados potenciais doadores de nitrosônio $\left(\mathrm{NO}^{+}\right)^{9}$. Esta molécula pode ser transferida para hidroxilas, aminas ou tióis, levando à formação de nitrito, $N$-nitrosaminas e $S$ nitrosotióis (Beckman, 1996, Barreto, 2005).

Altas concentrações de NO favorece sua reação com o ânion superóxido, aumentando a formação de peroxinitrito $\left(\mathrm{ONO}_{2}^{-}\right.$; Beckman e Koppenol, 1996, Barreto, 2005). peroxinitrito, após protonação pode gerar ácido peroxinitroso $\left(\mathrm{HONO}_{2}\right)$, que se decompõe rapidamente, produzindo dióxido de nitrogênio e o radical hidroxila, capaz de iniciar a peroxidação de lipídeos, bem como o radical $\mathrm{NO}_{2}$, o qual pode promover nitração de resíduos de aminoácidos aromáticos, como tirosina e triptofano, levando, por exemplo, à formação de 3-nitrotirosina (3-NT)(Eiserich et al, 1996, Gatti, 1994; King, 1993).

A peroxidação lipídica, deterioração oxidativa de lipídeos poliinsaturados, incluindo-se as lipoproteínas das membranas celulares pode reduzir a fluidez das membranas, aumentar sua permeablidade e danificar proteínas, levando a inativação de enzimas e canais iônicos. A lipoperoxidação gera malondialdeído (MDA) que pode ser mensurado através dos produtos de reação do ácido tiobarbitúrico (TBARS).

A nitração de resíduos tirosina em proteínas funciona como um biomarcador, permite investigar a geração de NO e outros oxidantes derivados deste, tais como dióxido de nitrogênio e ânion peroxinitrito. Entretanto, a nitração de tirosina pode ocorrer também na 
presença de hemoproteínas que possuem atividade peroxidase, tais como a mieloperoxidase (MPO), enzima abudante em grânulos azurófilos de neutrófilos. Na presença de $\mathrm{H}_{2} \mathrm{O}_{2}$, estas enzimas oxidam íon nitrito a dióxido de nitrogênio e resíduos de tirosina ao radical tirosila. A combinação desses radicais também produz a 3-nitrotirosina (3-NT, Augusto, 2006)

A expressão gênica das isoformas de NOS pode ser regulada por uma série de condições; LPS ou citocinas promove aumento da transcrição de iNOS e redução do conteúdo de RNAm e de proteínas de nNOS e eNOS em vários tipos celulares, por exemplo aorta, pulmão e cérebro (Scott, 2002 e Lee et al, 1995).

A atividade enzimática das isoformas de NOS, pode ser regulada por modificações póstraducionais, tais como fosforilação de resíduos específicos, o que pode inibir a atividade, como no caso da fosforilação de Ser847 na nNOS (Koneima et al, 2000) ou fosforilação em Ser635, Ser1179 e Thr497, que induzem aumento da atividade da eNOS (Boo et al, 2003; Lin et al 2003). Outros fatores envolvidos na regulação da atividade das NOS são disponibilidade de cofatores e substratos e a presença de inibidores endógenos.

A relação entre o NO e doença periodontal não está totalmente esclarecida e há informações limitadas e algumas vezes controversas sobre sua produção na cavidade bucal.

Foram observadas concentrações reduzidas de íon nitrito em saliva de pacientes com periodontite quando comparadas com sujeitos sadios (Auer et al., 2001); outros autores afirmam que a produção de NO estaria aumentada no tecido gengival de pacientes, com base no aumento observado nas concentrações dos aminoácidos L-arginina e L-citrulina, paralelo a um aumento de prostaciclina (Matejka et al., 1998). Contudo, esta afirmação não pode ser considerada conclusiva, pois há outras vias metabólicas nas quais a L-arginina e a Lcitrulina participam; como por exemplo, a via do ciclo da uréia, na qual a expressão da enzima arginase encontra-se aumentada em processos inflamatórios (Hesse et al., 2001).

Ratos com periodontite tratados com aminoguanidina, um inibidor de óxido nítrico, desenvolveram menor perda óssea, diminuição de parâmetros inflamatórios locais, tais como nitração de proteínas, peroxidação lipídica e infiltrado leucocitário (Di Paola et al., 2004). 


\subsection{Justificativa do projeto}

Muito embora a diminuição da secreção salivar esteja associada à maior incidência de cáries rampantes e, principalmente, à maior prevalência de doenças periodontais, nada se sabe, até o presente momento, sobre os possíveis efeitos que a doença periodontal pode exercer sobre a função e atividade das glândulas salivares. Ademais, pouco se conhece se esse efeito decorre de alterações nas glândulas salivares ou se esses seriam decorrentes da participação do fluido crevicular.

Partindo do pressuposto que a doença periodontal (periodontite) pode desempenhar um papel em alterações sistêmicas, como doenças cardíacas e renais, pensar-se-ia então que a presença da doença periodontal poderia também gerar respostas em estruturas mais próximas à cavidade bucal como, por exemplo, em glândulas salivares.

\subsection{Estratégia Experimental}

1. Investigar possíveis alterações de fluxo (estimulado ou não com pilocarpina) e composição salivar em animais submetidos à indução de periodontite; via implante de ligadura, após os intervalos de 3, 7 e 14 dias;

2. Correlacionar a perda óssea em ratos nesses animais a diferentes parâmetros salivares;

3. Avaliar a concentração / expressão de marcadores de estresse oxidativo e inflamatórios em glândulas salivares e em amostras de saliva;

4. Avaliar o papel funcional das glândulas salivares ex-vivo na produção da amilase 


\section{OBJETIVOS}

Tendo em vista a importância dos efeitos da doença periodontal na manutenção da saúde sistêmica e o papel das glândulas salivares nos mecanismos de defesa do organismo, este projeto se propôs a estudar os efeitos da doença periodontal induzida em diferentes parâmetros e saliva e glândulas salivares. 


\section{MATERIAL E MÉTODOS}

\subsection{Indução de doença periodontal em ratos}

Para a indução de doença periodontal, foram utilizados ratos Wistar machos pesando entre 180 e 220 g, provenientes do biotério central do Instituto de Ciências Biomédicas da Universidade de São Paulo (ICB/USP) os quais foram mantidos com livre acesso à ração e à água. Todos os protocolos experimentais foram aprovados pelo Comitê de Ética número: CEEA-ICB (protocolo 020, fls. 29, livro 2).

Os animais foram anestesiados com cetamina (80 mg/kg) e xilazina (20 mg/kg) e a periodontite foi induzida por meio do implante de fio de algodão ao redor da região cervical dos primeiros molares inferiores do lado direito. O fio foi atado pela face vestibular do dente, passado subgengivalmente do lado lingual e de forma supragengival para o lado vestibular. No grupo de animais controle (Sham), o fio de sutura foi retirado imediatamente

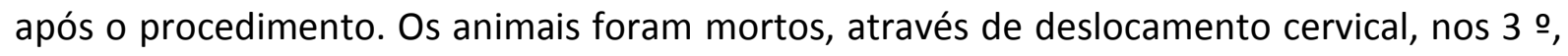
70 ou 14으 dia após o procedimento de implante da ligadura e outro grupo foi utilizado para realização de experimento in vitro.

\subsection{Mensuração da perda óssea}

Para efeitos de estudo da evolução temporal da perda óssea, as mandíbulas foram coletadas após o sacrifício dos animais para análises de radiografias digitais padronizadas usando-se um sistema de imagem computadorizada que utiliza um sensor com um filme de raio-x. A perda óssea alveolar foi calculada, nas películas de raio- $X$, através da mensuração da distância entre a junção cemento-esmalte e a crista óssea alveolar do primeiro molar inferior direito empregando o software AlphaEase FC (Alpha Innotech, EUA). 
O sensor foi exposto a $65 \mathrm{KV}$ e $10 \mathrm{~mA}$ com o tempo de exposição de 12 impulsos/segundo. A distância do cone até o filme foi de $50 \mathrm{~cm}$, e uma escala de alumínio foi colocada sobre o sensor para dar uma referência da densidade radiográfica.

A perda óssea de cada mandíbula foi avaliada por 3 examinadores independentes (que desconheciam o grupo ao qual pertencia cada amostra) e a média aritmética dos valores foi então calculada.

A.

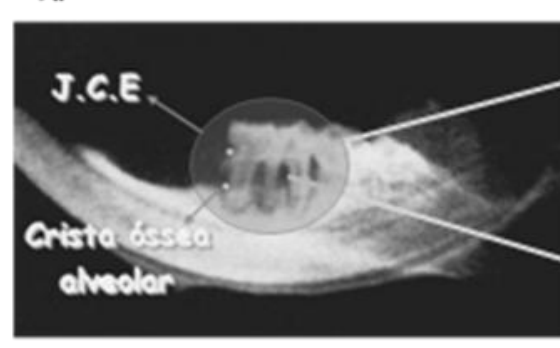

Figura 1. Película radiográfica e os pontos de análise utilizados (Imagem A). Aumento da área hachurada, com evidenciação dos pontos utilizados nas medições (Imagem B).

\subsection{Taxa de salivação não estimulada}

Na noite anterior à determinação da taxa de salivação e coleta das amostras de saliva (pelo menos $12 \mathrm{~h}$ ), os animais foram mantidos em gaiolas sem alimento sólido, podendo ingerir apenas água destilada. Falsos fundos colocados nas caixas garantiram o isolamento físico desses animais, a fim de evitar que eles ingerissem nitrato exógeno advindos das excretas e maravalhas.

Nos diferentes tempos de estudo, e previamente ao sacrifício, os animais foram anestesiados conforme descrito no item 3.1. Em seguida, discos de papel de filtro foram colocados no assoalho bucal para absorção da saliva pré-existente na cavidade bucal, tentando-se evitar a indução de salivação por qualquer trauma mecânico decorrente da secagem manual.

A seguir, cones de papel de filtro (Tanari, \#80) foram seccionados (5 mm de comprimento), pesados e posicionados no assoalho bucal durante 5 minutos e logo após retirados, pesados novamente. As diferenças de pesos (em $\mathrm{mg}$ ) foram divididas pelo tempo 
de duração da coleta (5 $\mathrm{min}$ ) para obtenção dos valores de fluxo salivar não estimulado. Os resultados foram expressos como variação percentual em relação ao grupo Sham.

\subsection{Indução da secreção salivar}

Para fins de coleta de quantidades apropriadas de saliva e para análise do fluxo salivar estimulado, a secreção salivar dos animais foi induzida através da administração de agonista muscarínico (pilocarpina, $1 \mathrm{mg} / \mathrm{kg}$; i.p.) após anestesia.

Antes do procedimento, as cavidades bucais dos animais foram enxaguadas com água deionizada (grau HPLC) em abundância. Imediatamente após a injeção da pilocarpina, e com a ajuda de pipetas de transferência de polietileno previamente enxaguadas com água desionizada, amostras de saliva foram coletadas (volume aproximado $200 \mu \mathrm{L}$ ) em tubos Eppendorf (os quais também passaram por uma lavagem prévia com água desionizada) e então armazenadas a $-70^{\circ} \mathrm{C}$. Os resultados foram expressos como variação percentual em relação ao grupo Sham.

\subsection{Taxa de salivação estimulada}

Após 15 minutos da injeção da pilocarpina foi avaliada a taxa de salivação estimulada. Para isso, discos de papel foram usados para secar as cavidades bucais dos animais e pequenas esferas de algodão hidrófilo (aproximadamente $3 \times 2 \mathrm{~mm}$ ) previamente pesados foram inseridos na cavidade bucal e mantidos durante 2 minutos. Após esse período as bolotas foram coletadas e pesadas, a subtração dos valores: final menos inicial, dividido pelo tempo de permanência na cavidade bucal, nos deu a taxa de salivação estimulada. Os resultados foram expressos como variação percentual em relação ao grupo Sham. 
Após os procedimentos de coleta de saliva, amostras de glândulas parótidas e submandibulares (tanto ipsilateral, quanto contralateral) foram cuidadosamente seccionadas, armazenadas em tubos de polietileno e imediatamente congeladas em gelo seco e mantidas a $-70{ }^{\circ} \mathrm{C}$ até o processamento das mesmas. As glândulas dos lados direito e esquerdo foram estocadas separadamente.

\subsection{Análise da concentração salivar de cálcio}

A concentração salivar de cálcio foi medida usando-se kit comercial (Labtest ${ }^{\circledast}$, São Paulo, Brasil) baseado na reação do cálcio com a púrpura de ftaleína em meio alcalino, resultando em um complexo de cor violeta. A intensidade da formação do cromóforo é proporcional à concentração de cálcio nas amostras.

Para tanto $5 \mu$ d de amostra foram pipetados em microplacas para leitor de ELISA e foram adicionados $250 \mu \mathrm{l}$ do reagente, composto por: tampão (700 mmol/L), o-cresolftaleina (80 $\mu \mathrm{mol} / \mathrm{L})$, 8-hidroxiquinoleina (3,4 mmol/L), ácido clorídrico (32 $\mathrm{mmol} / \mathrm{L})$ e azida sódica (15 mmol/L). Em paralelo foi realizada uma curva com o padrão, diluído entre 2,5 a 20 $\mathrm{mg} / \mathrm{ml}$. A leitura da absorbância foi medida a $570 \mathrm{~nm}$ em leitor de placas de ELISA (Molecular Devices, EUA). Os resultados foram expressos como variação percentual em relação ao grupo Sham.

\subsection{Determinação de proteínas totais da saliva}

Para analisar a concentração de proteínas na saliva foi utilizado o método de Peterson, baseado nas reações do reagente de biureto. $\mathrm{O}$ cobre em meio alcalino reage com a proteína gerando um complexo, este complexo formado pelo cobre e pela própria proteína apresenta aminoácidos fenólicos que reduzem o reativo de Folin resultando em coloração azulada. 
Calculam-se as taxas correspondentes numa curva de referência estabelecida com a solução padrão de albumina (10 $\mu \mathrm{g} / \mathrm{ml}$ a $100 \mu \mathrm{g} / \mathrm{mL})$.

As amostras foram diluídas (1:100) em água destilada, e a seguir adicionou-se o composto formado por: Sulfato cúprico pentahidratado $(0,2 \mathrm{~g} / \mathrm{L})$, tartarato duplo de sódio e potássio (0,4 g/L), carbonato de sódio (20 g/L),SDS 10\% (5 g/50 ml) e Hidróxido de sódio $0,8 \mathrm{~N}(3,2 \mathrm{~g} / 100 \mathrm{ml})$, as amostras foram agitadas e incubadas durante $10 \mathrm{~min}$. Adicionou-se, em seguida, o reagente Folin Ciocalteau 2N, realizando-se (nova) agitação e incubação por 40 minutos à temperatura ambiente. Procedeu-se, então, à leitura das absorbâncias a 700 $\mathrm{nm}$ contra água destilada em leitor de placas de ELISA (Molecular Devices, EUA).

A concentração de proteína e a produção salivar (quantidade de proteína gerada por minuto) foram expressas como variação percentual em relação ao grupo Sham.

\subsection{Proteinograma da saliva}

Para análise das proteínas presentes na saliva, realizou-se proteinograma. Para tanto, as amostras de saliva foram diluídas (1:4) em tampão TRIS-HCl 50 mM, pH 7,4 com adição de tampão de Laemmli (0,0625 M de Tris- $\mathrm{HCl}$, pH 6,8 contendo 2\% de SDS, $10 \%$ de glicerol, 0,001\% de azul de bromofenol e 5\% de 2-mercaptoetanol) na concentração final de $20 \mu \mathrm{g}$ de proteína.

As amostras foram aplicadas em gel de poliacrilamida a $12 \%$, aplicou-se também marcador de peso molecular. As proteínas foram separadas por eletroforese aplicando-se uma corrente constante de $10 \mathrm{~mA}$ durante aproximadamente cinco horas.

Os géis foram incubados em solução de ácido acético $5 \%$ e etanol $25 \%$ durante 30 minutos e corados utilizando Coomassie blue (Coomassie blue 0,25\%, metanol 50\% e ácido acético 7\%) durante 16 horas. Os géis foram então lavados em solução descorante (5\% de metanol e 7,5\% de ácido acético) e fotografados, usando-se o sistema Chemilmager 5500 (Alpha Innotech Corporation, CA, EUA).

As intensidades das bandas foram quantificadas por densitometria, empregando-se o software que acompanha o sistema de aquisição de imagens. 
3.10 Análise da cinética enzimática da $\alpha$-amilase

Os níveis de $\alpha$-amilase foram determinados na saliva; no liberado no meio de incubação ou nos sobrenadantes das glândulas dos experimentos in vitro (amilase total da glândula) usando-se um kit comercial (Laborlab ${ }^{\circledR}$, São Paulo, Brasil) um método cinético, que utiliza substrato Gal G2 - CNP (2-cloro-4-fenil-galactato piranosil maltodiose) que é diretamente hidrolisado pela $\alpha$-amilase produzindo cloronitrofenol (CNP).

Para tanto, $5 \mu \mathrm{l}$ das amostras foram pipetados em microplaca e foram adicionados $250 \mu \mathrm{l}$ de substrato, composto por: tampão biológico $(50 \mathrm{mmol} / \mathrm{L}$ ), cloreto de sódio(70 $\mathrm{mmol} / \mathrm{L})$, cloreto de cálcio(6 mmol/L), Gal G2 - CNP (2,27 mmol/L). As amostras, assim como o substrato, foram mantidos a $37^{\circ} \mathrm{C}$ e a reação foi realizada sob temperatura constante. $\mathrm{A}$ absorbância foi detectada a $405 \mathrm{~nm}$ em leitor de placas de ELISA, a $37^{\circ} \mathrm{C}$ (Molecular Devices, EUA). A concentração de $\alpha$-amilase foi calculada a partir da velocidade máxima da reação por segundo e o resultado foi expresso como variação percentual em relação ao grupo Sham.

\subsection{Determinação do conteúdo tecidual de produtos de reação do ácido tiobarbitúrico} (TBARS)

A determinação dos produtos de reação do ácido tiobarbitúrico analisa a quantidade de peroxidação lipídica mediante a quantificação dos aldeídos formados pela degradação de hidroperóxidos, incluindo o malondialdeído (MDA), descrito por Bird et al. (1984).

As amostras de glândulas submandibulares e parótidas foram pesadas e homogenizadas em 10 volumes de solução de fosfato de potássio $(50 \mathrm{mM}, \mathrm{pH} 7.4)$ contendo butil hidroxitolueno ( $\mathrm{BHT}, 12,6 \mathrm{mM}$ ). No caso de salivas, $40 \mu \mathrm{l}$ de saliva foram utilizadas somando-se $160 \mu \mathrm{l}$ de tampão fosfato. Alíquotas de $200 \mu \mathrm{L}$ do homogenato foram adicionadas a $400 \mu \mathrm{L}$ de solução contendo ácido tiobarbitúrico (0,37\%) em meio fortemente ácido (ácido tricloroacético a $15 \%$ e ácido clorídrico $0,25 \mathrm{~N}$ ) e então incubadas a $90{ }^{\circ} \mathrm{C}$ durante 45 minutos. 
As amostras foram centrifugadas durante 5 minutos a $10000 \mathrm{~g}$, e $300 \mu \mathrm{L}$ do sobrenadante foram submetidos à extração do produto de reação. Para tanto, $300 \mu \mathrm{L}$ de nbutanol juntamente com $30 \mu \mathrm{L}$ de solução aquosa saturada de cloreto de sódio foram agregados ao sobrenadante e agitadas utilizando-se vórtex durante 30 segundos. Após centrifugação (2 minutos a 10000 g) $200 \mu \mathrm{L}$ dos sobrenadantes (fase orgânica) foram pipetados em microplaca para leitura de ELISA dos valores de absorbância a $535 \mathrm{~nm}$ (corrigidos pelos valores de absorbância a $572 \mathrm{~nm}$ ).

Foi calculado $\mathrm{nmol}$ de aldeído formado por $\mathrm{mg}$ de tecido ou mg de proteína (Bose et al., 1989) utilizando-se para o cálculo um coeficiente de extinção molar de $1.55 \times 10^{5} \mathrm{M}^{-1} \mathrm{~cm}^{-}$ ${ }^{1}$. Os resultados foram expressos como variação percentual em relação ao grupo Sham.

\subsection{Determinação das concentrações salivares totais de nitrato + nitrito $\left(\mathrm{NO}_{x}\right)$ pelo método de Griess}

As amostras de saliva foram diluídas 1:10 em água desionizada (grau HPLC) e desproteinizadas por ultrafiltração (5.000 g durante $120 \mathrm{~min}$ a $4{ }^{\circ} \mathrm{C}$.) empregando-se tubos tipo Eppendorf providos de filtros de valor de cut-off de 5 kDa (Fisherbrand ${ }^{\circledR}$, Pittsburgh, PA).

A determinação de $\mathrm{NO}_{x}{ }^{-}$(nitrato + nitrito) nos ultrafiltrados foi realizada através da redução prévia do íon nitrato para nitrito pela nitrato redutase e posterior detecção do íon nitrito formado pelo método de Griess (diazotização / acoplamento).

A determinação de $\mathrm{NO}_{x}^{-}$(nitrato + nitrito) foi realizada incubando-se previamente as amostras e curva padrão (soluções aquosas de nitrato de potássio entre 0,2 e $200 \mu \mathrm{M}$ ), com NADPH (100 $\mu \mathrm{M}$; Sigma Chem. Co., EUA), FAD (5 $\mu \mathrm{M}$; Sigma Chem. Co., EUA) e nitrato redutase $(200 \mathrm{mU} / \mathrm{mL})$ durante 1 hora a $37{ }^{\circ} \mathrm{C}$ para redução do íon nitrato para nitrito. $\mathrm{O}$ excesso de NADPH foi eliminado através da adição de lactato desidrogenase (LDH, 13,5 $\mathrm{U} / \mathrm{mL}$; Calbiochem, EUA) e piruvato (90 mM; Sigma Chem. Co. EUA) e posterior incubação a $37{ }^{\circ} \mathrm{C}$ durante $30 \mathrm{~min}$. Por último, $50 \mu \mathrm{L}$ do reagente de Griess (solução contendo 0,1\% de sulfanilamida e 0,01\% de naftiletilenodiamina em ácido fosfórico à 5\%; Sigma Chem. Co., EUA) foram adicionados às amostras e após incubação durante $10 \mathrm{~min}$ à temperatura 
ambiente, foram realizadas as leituras dos valores de absorbância a $540 \mathrm{~nm}$ em leitor de placas de ELISA (Molecular Devices, EUA). Os resultados foram expressos como variação percentual em relação ao grupo Sham.

\subsection{Medida da atividade tecidual e salivar de mieloperoxidase (MPO) e peroxidase}

A medida de atividade de MPO baseia-se na velocidade de oxidação do substrato odianisidina na presença de água oxigenada, evidenciada pela mudança de coloração (Bradley et al., 1982).

As amostras de glândulas foram pesadas e homogeneizadas em 20 volumes $(p / v)$ de solução de fosfato de potássio $\mathrm{pH} 6,0$ contendo $0,5 \%$ brometo de hexadeciltrimetilamônio (HTAB, Sigma Chem. Co, EUA,) Para as salivas foram utilizados $20 \mu \mathrm{l}$ de saliva adicionando-se $20 \mu$ de tampão fosfato e HTAB.

Os homogenatos foram sonicados por 20 segundos, aquecidos durante duas horas a $60{ }^{\circ} \mathrm{C}$ para inativação da catalase endógena (Ohta, 2002) e centrifugados a 10.000 g por 2 minutos.

A $10 \mu \mathrm{L}$ dos sobrenadantes foram acrescentados $200 \mu \mathrm{L}$ de solução de fosfato de potássio ( $5 \mathrm{mM}, \mathrm{pH}$ 6) contendo $16,7 \mathrm{mg} / \mathrm{mL}$ de o-dianisidina (Sigma Chem. Co., EUA) e $0,0005 \%$ de $\mathrm{H}_{2} \mathrm{O}_{2}$ em microplaca.

O monitoramento da velocidade de formação do produto de oxidação da o-dianisidina foi realizado registrando-se o aumento da absorbância da mistura a $460 \mathrm{~nm}$ (leituras coletadas em intervalos de 10 segundos durante 10 minutos). A atividade de MPO foi calculada a partir da velocidade máxima da reação por segundo e o resultado foi expresso em UMPO/mg de tecido ou por UMPO/ml. Uma unidade de MPO é definida como a quantidade em $\mu \mathrm{mol}$ de $\mathrm{H}_{2} \mathrm{O}_{2}$ degradado por minuto.

A análise da densidade ótica $(460 \mathrm{~nm})$ foi realizada em leitor de placas de ELISA (Molecular Devices, EUA), a cada intervalo de $10 \mathrm{~s}$, durante $10 \mathrm{~min}$. A atividade da enzima MPO em unidades e corrigida pela quantidade de tecido $(\mathrm{g})$ utilizado no ensaio, segundo a fórmula: MPO $(\mathrm{U} / \mathrm{g})=\mathrm{Vmax} / \mathrm{s} \times 60 / 0,0113 / 0,5$. Considerou-se que uma unidade de 
atividade de MPO corresponde àquela capaz de degradar um micromol de $\mathrm{H}_{2} \mathrm{O}_{2}$ por minuto (Bradley et al., 1982). Os resultados foram expressos como variação percentual em relação ao grupo Sham.

\subsection{Análise da expressão de resíduos protéicos de nitrotirosina (NT)}

As amostras foram pesadas e homogenizadas em 10 volumes de tampão Tris- $\mathrm{HCl} 50$ mM (Tris- $\mathrm{HCl} 50$ mM, pH 7,4 contendo 1 mM de PMSF, leupeptina $10 \mu \mathrm{g} / \mathrm{ml}$, inibidor de tripsina $10 \mu \mathrm{g} / \mathrm{ml}$ e $1 \mathrm{mM}$ de L-cit) e centrifugadas durante 5 minutos a $1000 \mathrm{~g}$ e $4^{\circ} \mathrm{C}$.

A concentração de proteínas totais nas amostras foi determinada através do método de Braford (1976). A curva padrão foi realizada utilizando-se uma solução de albumina de soro bovino nas concentrações de 2,5, 5, 10, 20, 30, 40 e $50 \mu \mathrm{g} / \mathrm{ml}$. As amostras foram devidamente diluídas em água Milli-Q e reagente de Bradford e a leitura de absorbância a $595 \mathrm{~nm}$ foi realizada em leitor de placas de ELISA (Molecular Devices, EUA).

As amostras foram então transferidas $(0.5 \mu \mathrm{g})$ para uma membrana de nitrocelulose através do sistema slot blot utilizando-se vácuo. As membranas foram então coradas com solução de vermelho de Ponceau e fotografadas a fim de se verificar a eficiência da transferência (e foram descoradas com água).

O bloqueio de sítios inespecíficos presentes nas membranas de nitrocelulose foi realizado através da incubação das membranas com uma solução de caseína $(0,2 \%$ em TBS-t) por uma hora, sob agitação contínua.

Após esse período, as membranas foram incubadas com o anticorpo primário anti nitro-tirosina (camundongo), na diluição de $500 \mathrm{ng} / \mathrm{mL}$ em TBS-t, durante $16 \mathrm{~h}$ sob agitação contínua a $18^{\circ} \mathrm{C}$.

As membranas foram lavadas com TBS-t e incubadas com o anticorpo secundário de coelho anti-camundongo conjugado com fosfatase alcalina na diluição de 1:3000 em TBS-t por duas horas, foram posteriormente lavadas com TBS-t e submetidas à revelação. 
Um mililitro de substrato mais $50 \mu \mathrm{L}$ de intensificador foram incubados com as membranas durante 5 minutos. A captação dos sinais de quimioluminiscência foi feita em sistema Chemilmager 5500 (Alpha Innotech Corporation, CA, EUA).

As intensidades das bandas foram quantificadas por densitometria, empregando-se o software que acompanha o sistema de aquisição de imagens. Os resultados foram expressos como variação percentual em relação ao grupo Sham.

3.15 Atividade funcional "ex vivo" de glândulas submandibulares e sublinguais"

Após anestesia e previamente ao sacrifício dos animais, as glândulas submandibulares e sublinguais foram removidas e incubadas em tampão Krebs-Ringerbicarbonato sem glicose, sob borbulhamento do gás carbogênio $\left(5 \% \mathrm{O}_{2}\right.$ em $\left.\mathrm{CO}_{2}\right)$ a $37{ }^{\circ} \mathrm{C}$ durante $10 \mathrm{~min}$, após esses 10 minutos, $300 \mu \mathrm{l}$ desse meio e as glândulas foram removidas do meio e armazenadas a $-80{ }^{\circ} \mathrm{C}$. Posteriormente, as glândulas foram homogenizadas a $4{ }^{\circ} \mathrm{C}$ em $500 \mu \mathrm{l}$ em tampão Krebs bicarbonato contendo inibidores de protease (aprotinina1 $\mu \mathrm{g} / \mathrm{ml}$, leupeptina $2 \mu \mathrm{g} / \mathrm{ml}$, inibidor de tripsina tipo soybean $3 \mu \mathrm{g} / \mathrm{ml}$, fenilmetilsulfonil fluoreto (PMSF) $2 \mu \mathrm{g} / \mathrm{ml}$ )

Os homogenatos e o meio foram centrifugados a $10.000 \mathrm{Xg}$ a $4{ }^{\circ} \mathrm{C}$ durante $5 \mathrm{~min}$ e a atividade da $\alpha$-amilase foi determinada. Os resultados foram expressos como variação percentual em relação ao grupo Sham.

\subsection{Avaliação dos níveis de citocinas nas glândulas salivares}

As medidas das concentrações das citocinas INF, IL-5, IL-4, IL-13, IL-10, TNF, IL6 e IL1 $\beta$ nas amostras de glândulas salivares foram realizadas usando-se o teste imunoenzimático (ELISA), segundo as instruções do fabricante (ReD System, EUA).

As amostras foram pesadas e homogeneizadas em 10 volumes de tampão Tris- $\mathrm{HCl} 50$ $\mathrm{mM}$ (Tris-HCl 50 mM, pH 7,4 contendo $1 \mathrm{mM}$ de PMSF, leupeptina $10 \mu \mathrm{g} / \mathrm{ml}$, inibidor de tripsina $10 \mu \mathrm{g} / \mathrm{ml}$ e $1 \mathrm{mM}$ de L-cit) e centrifugadas durante 5 minutos a $1000 \mathrm{~g} \mathrm{e} 4{ }^{\circ} \mathrm{C}$. 
A seguir, o sobrenadante foi pipetado (em duplicata) em microplacas de 96 poços previamente sensibilizadas $\left(18\right.$ horas, $4^{\circ} \mathrm{C}$ ) com $100 \mu \mathrm{l}$ de anticorpo monoclonal para cada citocina em tampão carbonato $(0,1 \mathrm{M}, \mathrm{pH} 9,6)$. A leitura das placas foi realizada em leitor de placas de ELISA (Molecular Devices, EUA). nos comprimentos de ondas que variaram de 450 $\mathrm{nm}$ a $570 \mathrm{~nm}$. As concentrações das amostras foram calculadas a partir das curvas-padrão obtidas com as citocinas recombinantes. O limite de detecção foi $\mathrm{pg} / \mathrm{ml}$. Os resultados foram expressos como variação percentual em relação ao grupo Sham.

\subsection{Medida da atividade de óxido nítrico sintase (NOS)}

A atividade da NOS em glândulas salivares foi estimada pelo método de conversão da $\left[{ }^{3} \mathrm{H}\right] \mathrm{L}-\arg$ para $\left[{ }^{3} \mathrm{H}\right] \mathrm{L}-\mathrm{cit}$ (Hiki et al., 1992).

Os tecidos foram pesados e homogeneizados a 1:10 em tampão (Tris- $\mathrm{HCl} 50$ mM, pH 7,4; $1 \mathrm{mM}$ de PMSF, leupeptina $10 \mu \mathrm{g} / \mathrm{ml}$, inibidor de tripsina $10 \mu \mathrm{g} / \mathrm{ml}$ e $1 \mathrm{mM}$ de L-cit) e passados em resina de troca iônica (tipo aniônica forte, Dowex AG 50X-8) para eliminação da L-arg endógena. Para avaliação da atividade enzimática total, um primeiro tubo recebeu uma alíquota do eluato $(50 \mu \mathrm{l})$ que foi incubado à temperatura de $37{ }^{\circ} \mathrm{C}$ durante 10 minutos na presença de $10 \mu \mathrm{l}$ de $\mathrm{CaCl}_{2} 10 \mathrm{mM}$, e dos cofatores (FAD $100 \mu \mathrm{M}, \mathrm{NADPH} 100 \mu \mathrm{M}, \mathrm{BH} 4100$ $\mu \mathrm{M}$, calmodulina $3 \mathrm{U} / \mathrm{ml}$ ) e $1 \mu \mathrm{M} \mathrm{L}$-arg contendo o marcador $\left[2,3,4,5-{ }^{3} \mathrm{H}\right] \mathrm{L}$-arginina mono hidrocloreto (que corresponde à 100000 com; AmerSham Biosciences, EUA) num volume final de $100 \mu \mathrm{l}$. O segundo tubo recebeu outra alíquota de amostra no qual foi acrescentado, juntamente com os cofatores e a arginina marcada, o EGTA $1 \mathrm{mM}$, porém neste tubo foi suprimido o $\mathrm{CaCl}_{2}$ (para avaliação da atividade enzimática $\mathrm{Ca}^{2+}$-independente). Um terceiro tubo recebeu os mesmos reagentes do primeiro tubo, acrescido de L-NAME 1 mM (inibidor não seletivo de NOS), e sua atividade corresponde à produção de citrulina via "não NOS". Assim, a atividade total da NOS corrigida corresponde à atividade do primeiro tubo subtraído do valor da atividade do terceiro tubo. Um quarto tubo recebeu os mesmos reagentes do segundo tubo, acrescido também de L-NAME. Assim, a atividade de NOS $\mathrm{Ca}^{++}$dependente corrigida corresponde ao valor obtido do segundo tubo subtraído do valor encontrado no quarto tubo. O valor da atividade de $\mathrm{NOS} \mathrm{Ca}_{2}{ }^{+}$-independente corresponde ao 
valor corrigido para atividade de NOS subtraído do valor corrigido para a atividade da NOS $\mathrm{Ca} 2^{+}$-dependente.

Após a incubação, a reação foi interrompida pela adição de tampão HEPES pH 5.4 contendo EGTA e EDTA. Os homogenatos foram aplicados novamente em colunas contendo resina Dowex AG 50X-8, lavados em $1 \mathrm{~mL}$ de tampão aplicado sobre a resina e recolhidos em viais de cintilação. Após a adição de $10 \mathrm{~mL}$ do líquido de cintilação, a radioatividade foi determinada em espectrofotômetro de cintilação líquida. Para o cálculo das atividades enzimáticas, as leituras corrigidas (em contagens por minuto, $\mathrm{cpm}$ ) são relacionadas à leitura da $\left[2,3,4,5-{ }^{3} \mathrm{H}\right] \mathrm{L}-\mathrm{arg}$ mono hidrocloreto adicionada diretamente no vial de cintilação (sem passagem através da coluna de troca iônica) e correspondem a: pmol L-cit/min $=1000 \mathrm{x}$ $\left(\mathrm{cpm}_{\text {amostra }}-\mathrm{cpm}\right.$ L-NAME) / $\mathrm{cpm}_{\text {totais }} / 10$ (onde 1000 representa a quantidade de L-arginina adicionada à mistura de incubação (em pmols) e 10 foi o tempo de incubação (em min)).

O conteúdo de proteínas foi determinado por colorimetria, empregando-se o reagente Coomasie brilliant blue (Bradford, 1976) para que a atividade da NOS fosse expressa como pmols de L-cit produzidos por minuto e por mg de proteína.

\subsection{Avaliação da expressão gênica de óxido nítrico sintase}

A presença de mRNA para as isoformas de NOS, como medida do grau de expressão gênica, foi avaliada pela reação em cadeia da polimerase após transcrição reversa (qPCR) em tempo real. Amostras da glândula submandibular foram removidas e imediatamente armazenadas em gelo seco e mantidas a $-80^{\circ} \mathrm{C}$ até o seu processamento.

\subsubsection{Extração do RNA total}

O RNA total foi extraído usando-se o reagente Trizol (Gibco BRL, EUA), conforme o método indicado pelo fabricante, posteriormente dissolvido em água tratada com DEPC e a 
integridade do RNA isolado foi verificada através de eletroforese em gel de agarose contendo brometo de etídio para revelação das bandas sob luz ultravioleta.

Posteriormente, o RNA foi dissolvido em $50 \mu$ l de água tratada com DEPC. Alíquotas desta solução foram diluídas 1:1000, as absorbâncias medidas a $260 \mathrm{~nm}$ e as concentrações de RNA total foram calculadas considerando a relação: $1 \mathrm{AU}=40 \mu \mathrm{g} / \mathrm{ml}$.

\subsubsection{Transcrição do cDNA}

Cuidadosamente, $1 \mu$ l de oligo dT (GIBCO BRL, EUA) $4 \mu$ l de tampão de reação (5X first strand buffer), $1 \mu$ l de dNTP (10 mM, AmerSham, Inglaterra), $2 \mu$ de DTT (0,1 M), $1 \mu$ de inibidor de RNAses (RNAseOUT, AmerSham, Inglaterra) $1 \mu$ lde DNAse 1 e $3 \mu$ de RNA foram misturados. A mistura foi aquecida a $37{ }^{\circ} \mathrm{C}$ durante 10 minutos e $75{ }^{\circ} \mathrm{C}$ por 5 minutos, posteriormente adicionou-se $1 \mu$ da enzima RT (transcriptase reversa - MMLV, GIBCO BRL, EUA) e novamente aquecida a $37^{\circ} \mathrm{C}$ por $1 \mathrm{~h}$. Posteriormente, as amostras foram aquecidas a $75^{\circ} \mathrm{C}$ durante 15 min e a $37^{\circ} \mathrm{C}$ por 2 min e mantidas a $-20^{\circ} \mathrm{C}$, até serem submetidas ao PCR.

3.18.3 Reação em cadeia da polimerase (qPCR) quantitativa em tempo real

Os primers utilizados foram diluídos a uma concentração de 100 pmoles/ $\mu$ l (solução estoque) com $\mathrm{H}_{2} \mathrm{O}$ Milli-Q autoclavada.

A reação de qPCR foi realizada em um volume final de $12 \mu$ l contendo $3 \mu$ de cDNA (amostra), diluído 1:10; $1,5 \mu$ l do primer $1(0,3 \mu \mathrm{M}), 1,5 \mu$ do primer $2(0,3 \mu \mathrm{M})$ e $6 \mu \mathrm{l}$ de Syber Green. O primer de HPRT1 (hipoxantina guanina fosforibosil transferase) foi utilizado como gene normalizador.

As amostras da reação, pipetadas em duplicatas, foram adicionadas à placa de 96 poços (MicroAmp, Applied Biosystems, EUA) para amplificação e leitura no equipamento Mx3000P (Stratagene, EUA). O equipamento para os ciclos de amplificação a seguir: 10 min a $94{ }^{\circ} \mathrm{C}$ para ativação da enzima, seguido por 40 ciclos de amplificação. 
A normalização foi realizada utilizando-se como controle interno a expressão gênica da hipoxantina-guanina fosforibosiltransferase (HPRT). Todos os primers apresentaram eficiência $>90 \%$ conforme o requerido para a quantificação através do algoritmo $2^{-\Delta \Delta C t}$.

Tabela 1 - Desenho dos primers utilizados para realização da qPCR

\begin{tabular}{ccc}
\hline Gene & Sequência “forward” (5'-3') & Sequência “reversa” (5'-3') \\
\hline eNOS & AGCATGAGGCCTTGGTATTG & CCCGACATTTCCATCAGC \\
iNOS & AAAATGGTTTCCCCCAGTTC & GTGGATGGAGTCACATGCAG \\
nNOS & CACCTGAAGAGCACACTGGA & GGCTAGAGGGAAGAGCTGGT \\
HPRT & AAGCTTGCTGGTGAAAAGGA & TGATTCAAATCCCTGAAGTGC \\
\hline
\end{tabular}

\subsection{Análise estatística}

Os resultados foram expressos como médiaterro padrão da média (EPM). A análise estatística foi realizada utilizando-se o teste $t$ não pareado. Valores de $p<0,05$ foram considerados como estatisticamente significantes. 


\section{RESULTADOS}

\subsection{Análise da perda óssea alveolar}

A perda óssea foi calculada por meio do método radiográfico, mensurando a distância entre a junção esmalte-cemento (JEC) e a crista óssea alveolar após 3, 7 ou 14 dias da indução da doença periodontal pelo implante da ligadura.

Conforme mostrado na Figura 1, não foram encontradas diferenças significativas entre os grupos controle (Sham, sem ligadura) e o grupo que recebeu implante de ligadura quando avaliado após 3 dias $(0,080 \pm 0,012$ vs. 0,112 $\pm 0,014 \cup A ; p>0,05)$. As análises realizadas após 7 ou 14 demonstraram que houve aumento significativo na distância entre a junção esmalte-

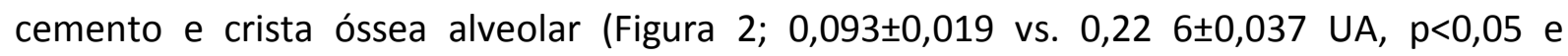
$0,093 \pm 0,027$ vs. $0,285 \pm 0,027 \cup A, p<0,001)$. 
A.

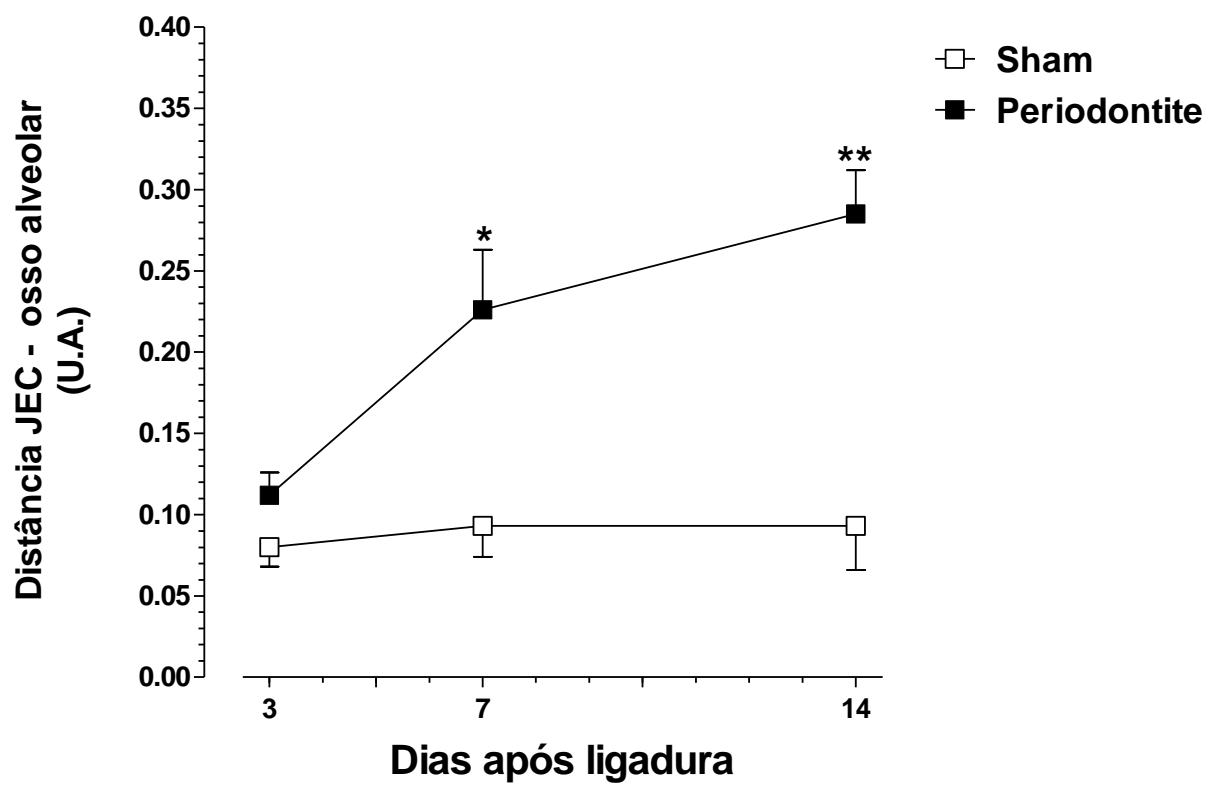

B.

- Grupo/ Tempo após ligadura 3 dias $\quad 7$ dias 14 dias

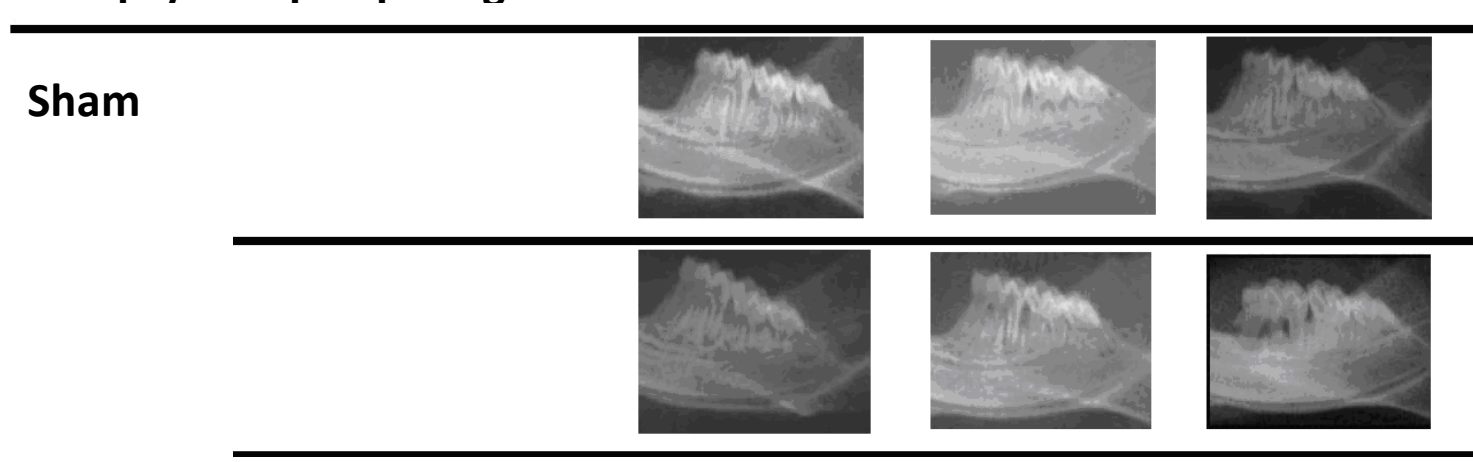

Figuı

la perda óssea alveolar. As mandíbulas de animais Sham e que passaram pelo imento de implante de ligadura, foram avaliadas 3, 7 e 14 dias após a indução da ı. (Painel A) A perda óssea foi estimada como distância entre a junção esmalteto (JEC) e o topo do osso alveolar nos molares inferiores direitos. Valores sos como unidades arbitrárias (U.A.). ${ }^{*} p<0,05$ e ${ }^{* *} p<0,001$ vs. Sham. Teste t não o. (Painel B) Imagem ilustrativa das tomadas radiográficas nos diferentes tempos e grupos. 
4.2 Taxa de salivação

Como pode ser observado no painel A da Figura 3, após 3 dias de indução da doença periodontal, não houve diferenças significativas entre o grupo periodontite e o grupo Sham

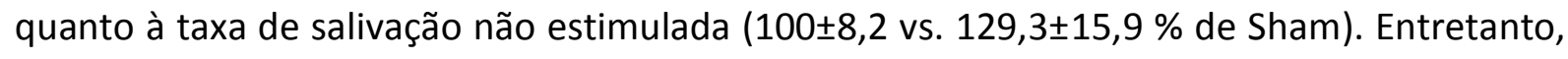
quando da estimulação da secreção de saliva utilizando pilocarpina (painel B), observou-se aumento do fluxo nos animais que tiveram o implante de ligadura, em comparação com os animais que passaram pelo procedimento simulado (100 \pm 2.6 vs. $114.6 \pm 5.1 \%$ de Sham, $p<0,05)$.

Após 7 dias de indução da doença periodontal, a taxa de salivação não estimulada foi significativamente reduzida, (Figura 3, painel C; $100 \pm 6,3$ vs. 79,9 $\pm 5.1 \%$ de Sham, $p<0,05$ ), assim como a estimulada por pilocarpina (Figura 3, painel D; $100 \pm 4,3$ vs. 79,7 $\pm 6,91 \%$ de Sham, $p<0,05)$ em relação ao grupo Sham.

Aos 14 dias de indução de doença periodontal, a taxa de salivação (tanto não estimulada, quanto a estimulada) não se mostraram significativamente diferentes (Figura 3, painéis $E$ e $F ; 100 \pm 6,5$ vs. $98,8 \pm 8,5 \%$ e $100 \pm 3,92$ vs. $89,2 \pm 7,7 \%$ de Sham). 
A.

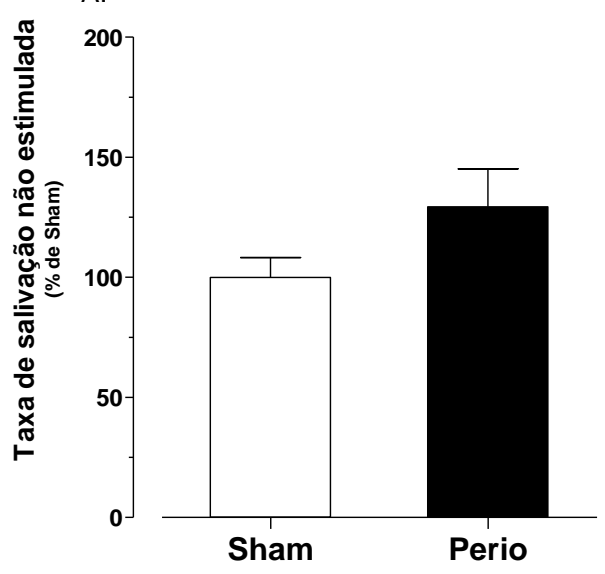

c.



E.

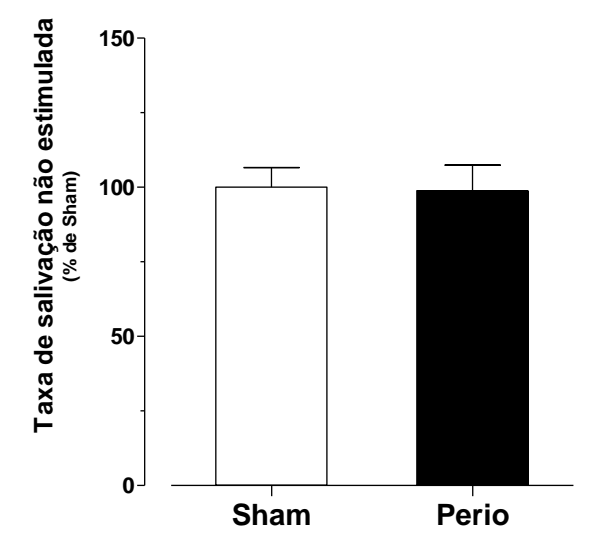

B.

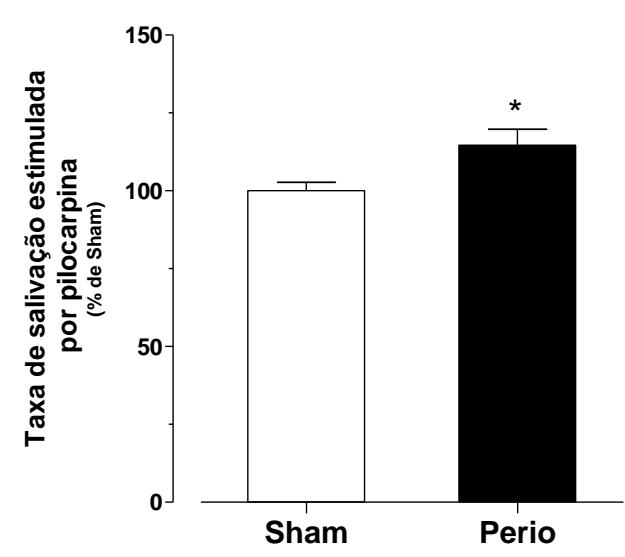

D.

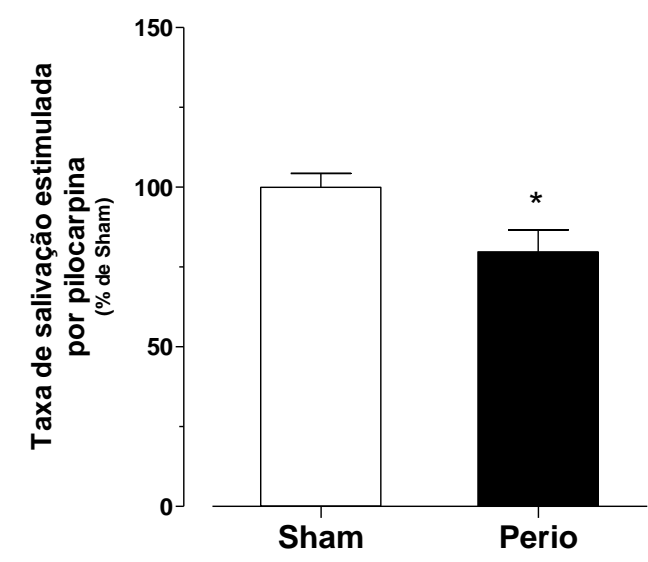

F.

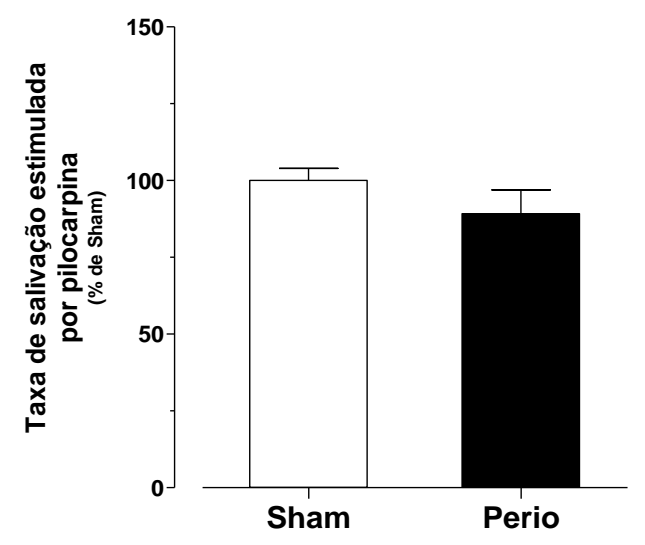

Figura 3. Análise do fluxo salivar não estimulado ou estimulado. Foram avaliados os fluxos salivares após 3 (painéis $A$ e B), 7 ( painéis $C$ e D) ou 14 (painéis E e F) dias após a indução da doença periodontal ou do procedimento simulado $(n=11-12)$. O fluxo salivar foi mensurado após estimulação ou não com pilocarpina. Os dados foram plotados como médiatEPM para cada grupo e analisados pelo teste $t$ não pareado. ${ }^{*}(p<0,05)$ indica diferenças significativas em relação ao respectivo grupo controle - Sham 


\subsection{Cálcio salivar}

Após 3 dias da indução da doença periodontal, o grupo periodontite mostrou aumento significativo tanto a concentração de cálcio salivar (Figura 4, painel A; $100 \pm 1,3$ vs. $139 \pm 16 \%$ de Sham, p<0,05), quanto da secreção salivar de cálcio (Figura 4, painel B; $100 \pm, 1$ vs. $124 \pm 5,51 \%$ de Sham, p<0,001) em relação ao grupo Sham.

Após 7 dias dos procedimentos, não foram observadas diferenças significativas com

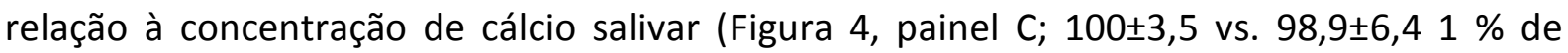

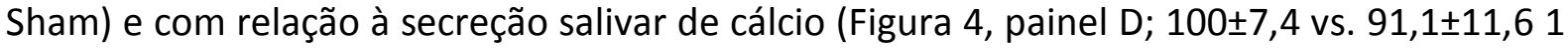
\% de Sham) do grupo periodontite em comparação ao grupo Sham.

Após 14 dias de indução de doença periodontal ou do procedimento simulado, não foram observadas diferenças significativas com relação à concentração de cálcio salivar (Figura 4, painel E; $100 \pm 4,6$ vs. 104,2 $44,91 \%$ de Sham) e com relação à secreção salivar de cálcio (Figura 4, painel F; $100 \pm 9,5$ vs. $95 \pm 12,1 \%$ de Sham) do grupo periodontite em comparação ao grupo Sham. 

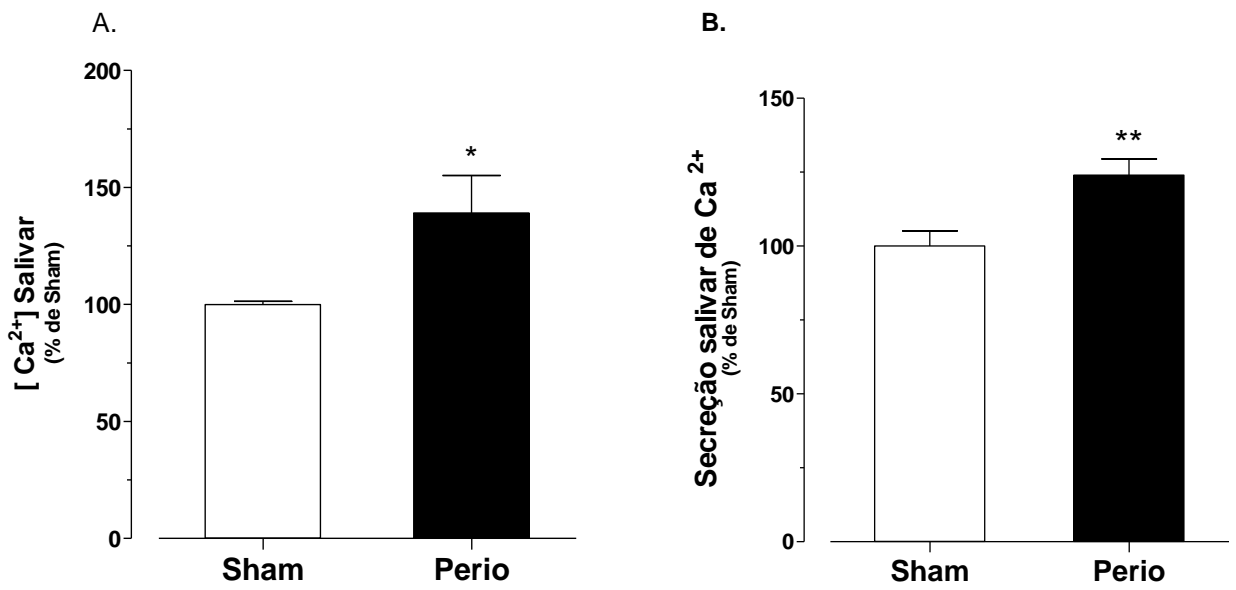

c.
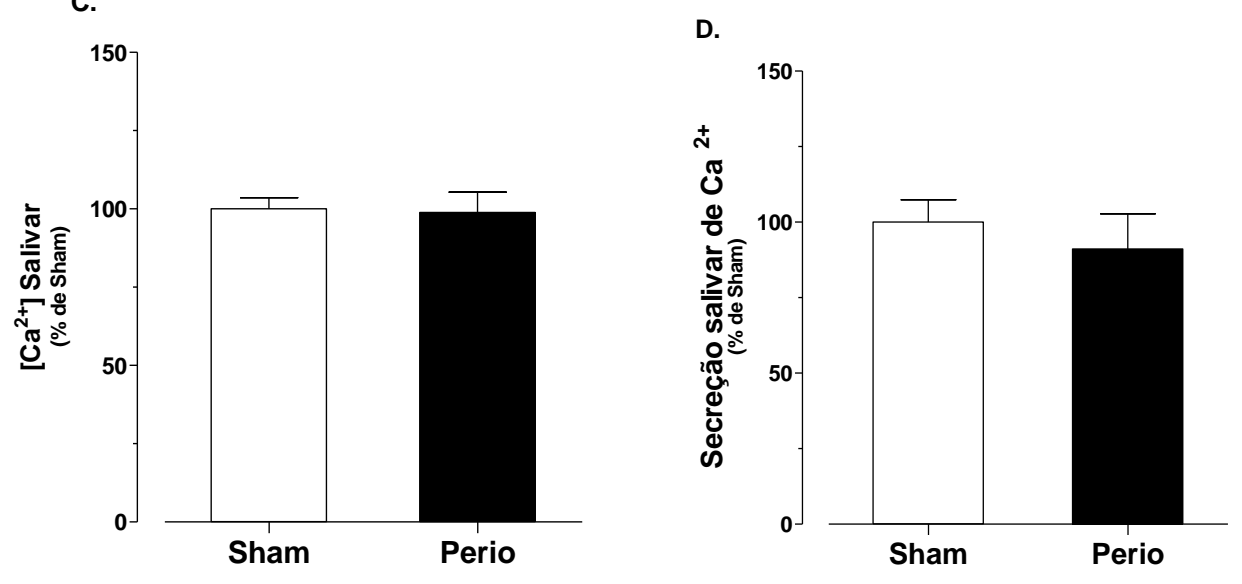

F.
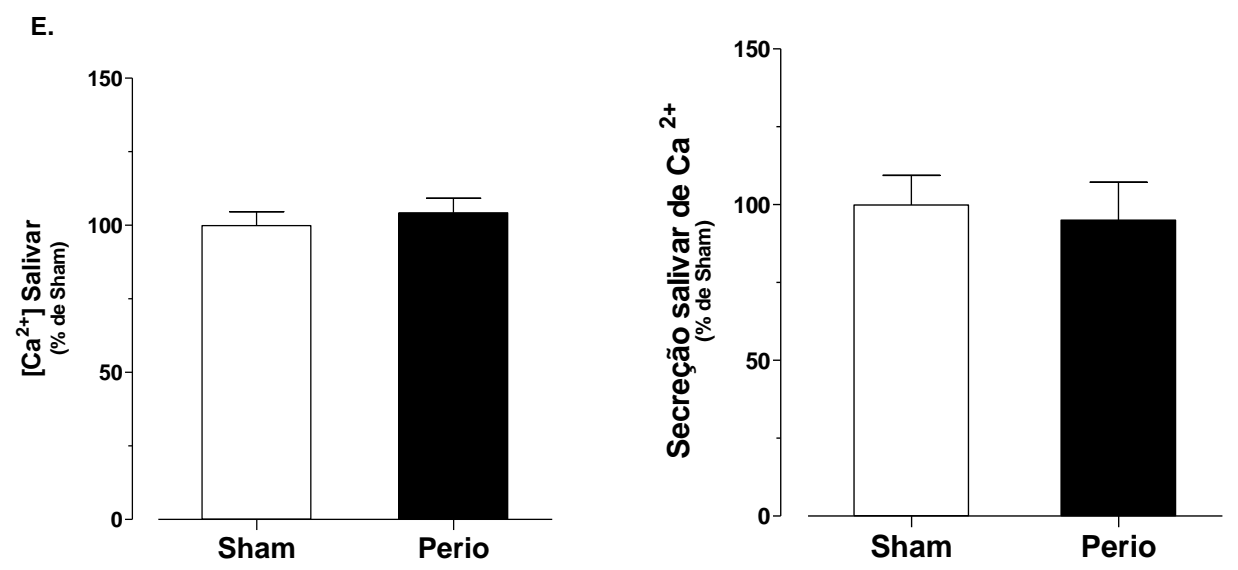

Figura 4. Medida da concentração e secreção de cálcio salivar. Mensuração de cálcio salivar em amostras de saliva obtidas após 3 (painéis $A$ e B), 7 (painéis $C$ e D) ou 14 (painéis E e F) dias após a indução da doença periodontal ou da simulação do procedimento ( $n=8-12$ ). Os dados foram plotados como médiatEPM para cada grupo e analisados pelo teste $t$ não pareado. ${ }^{*}(p<0,05)$ e ${ }^{* *}(p<0,01)$ indicam diferenças significativas em relação ao respectivo grupo controle - Sham. 


\subsection{Proteínas salivares totais}

Na Figura 5, observa-se que, após 3 dias da indução da doença periodontal, nos grupos com periodontite ou procedimento simulado não foram observadas diferenças significativas entre os grupos, quanto a concentração de proteínas totais salivares (painel A, $100 \pm 3,8$ vs. 103,5 $\pm 8,6$ \% de Sham). Porém, com relação à secreção de proteínas salivares foi observado aumento nos animais do grupo periodontite com relação ao grupo Sham (painel B, 100 $\pm 10,2$ vs. $148,7 \pm 12,21 \%$ de Sham, $p<0,05)$.

Após 7 dias de indução da doença periodontal, observa-se que as salivas dos animais do grupo periodontite não diferiram significativamente das salivas do grupo simulado com relação à concentração de proteínas totais (Figura 5, painel C; $100 \pm 7$ vs. $84,2 \pm 6,6 \%$ de Sham), entretanto, encontra-se diminuída quanto à produção de proteínas salivares (Figura 5 , painel $D ; 100 \pm 9,9$ vs. $74 \pm 7,7 \%$ de Sham, $p<0.05$ vs. Sham).

Após 14 dias, não foram observadas diferenças significativas entre as salivas dos animais do grupo periodontite e do grupo Sham, com relação à concentração de proteínas

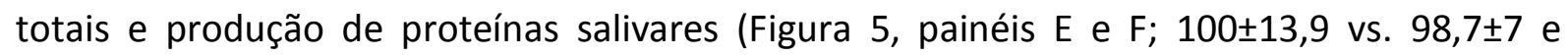
$100 \pm 11,4$ vs. $94,1 \pm 13,5 \%$ de Sham).

Além da mensuração das quantidades de proteína total presente na saliva realizou-se proteinograma para avaliar se a saliva dos animais submetidos à indução da doença periodontal apresentava padrão protéico distinto da saliva dos animais do grupo Sham, nos diferentes tempos de indução da doença. Como pode ser observado nas Figuras 6, 7 e 8, após 3, 7 e 14 dias da indução da doença, não havendo diferença significativa entre os grupos. 


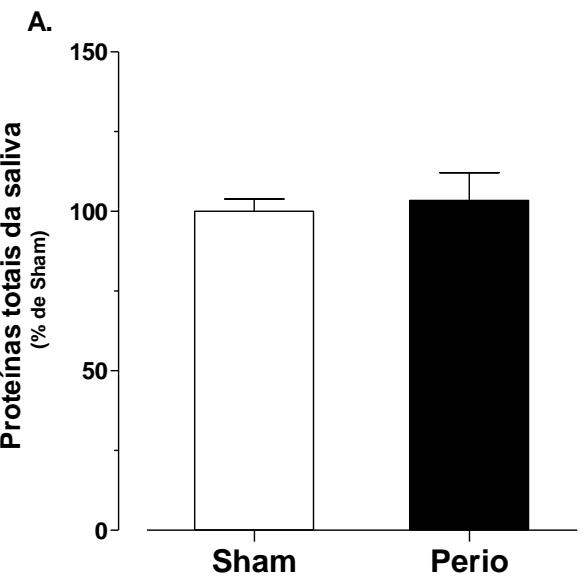

B.
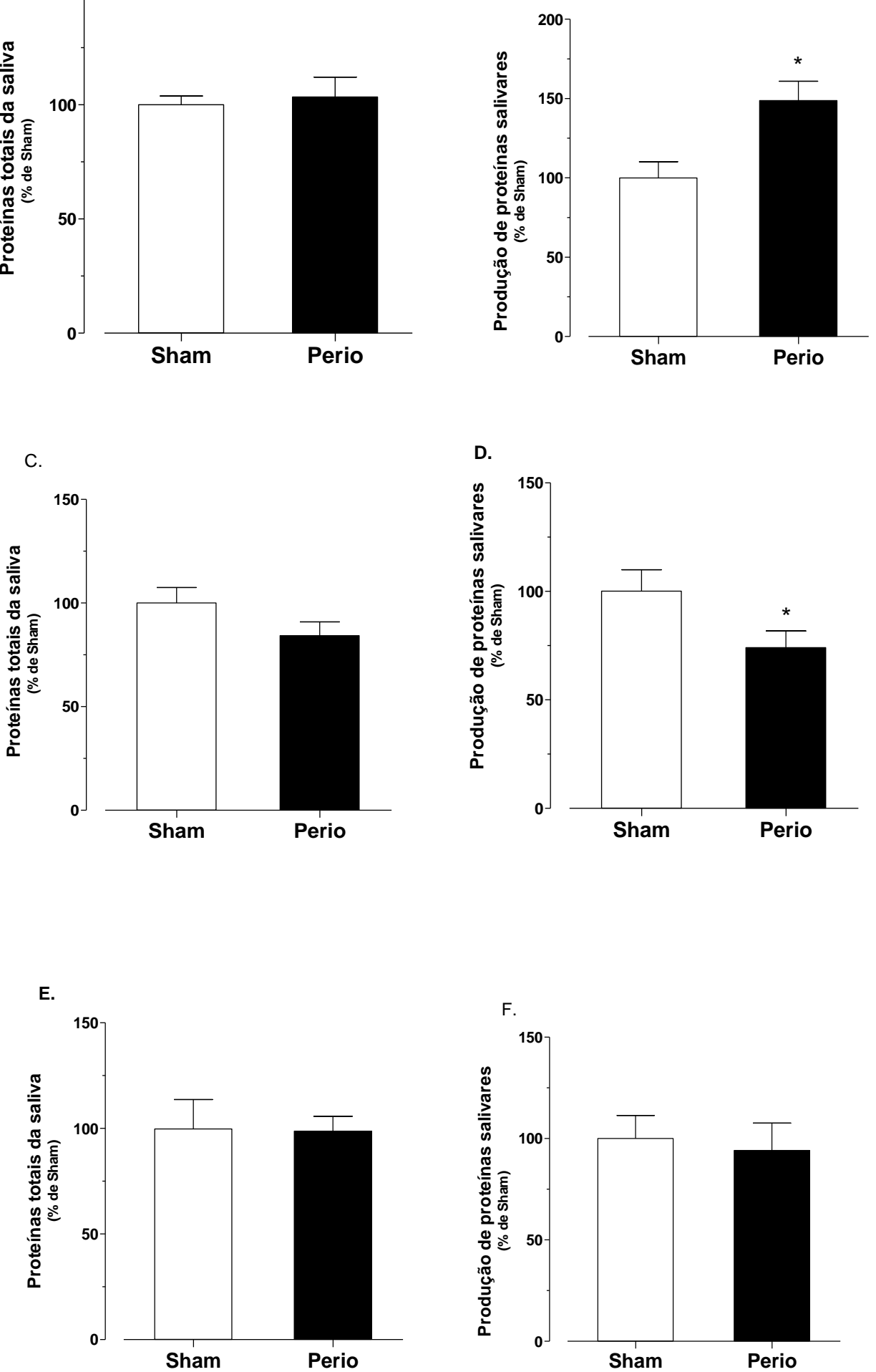

Figura 5. Concentração e taxa de secreção protéica salivares. Quantificação das proteínas salivares em amostras de saliva obtidas após 3 ( $A$ e B), 7 (C e D) ou 14 (E e F) dias da indução da doença ou da simulação do procedimento $(n=12-14)$. Os dados foram plotados como média $\pm E P M$ para cada grupo e analisados pelo teste $t$ não pareado. $*(p<0,05)$ indica diferenças significativas em relação ao respectivo grupo controle - Sham. 


\section{Proteinograma 3 dias}

A.

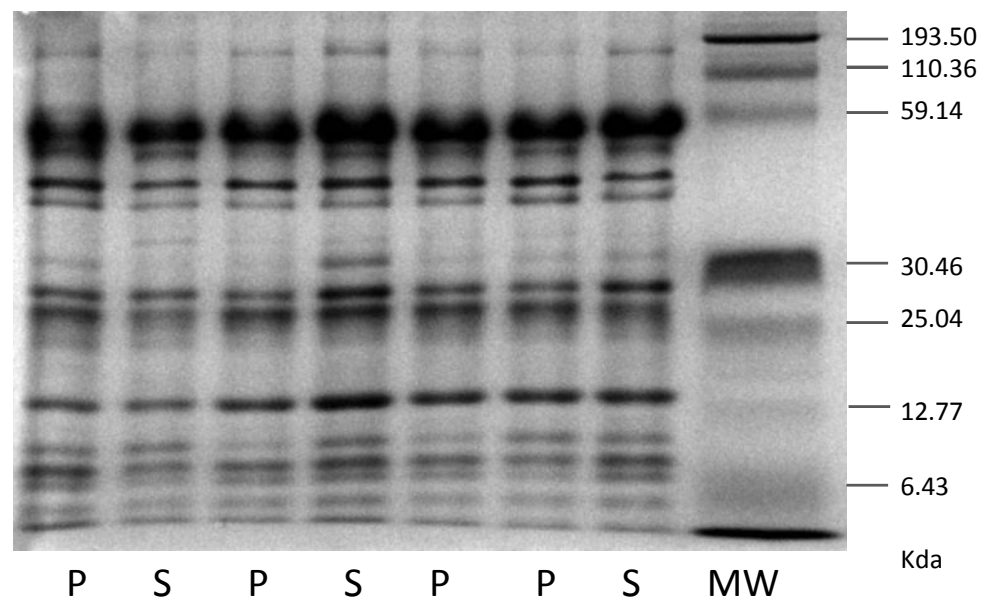

B.

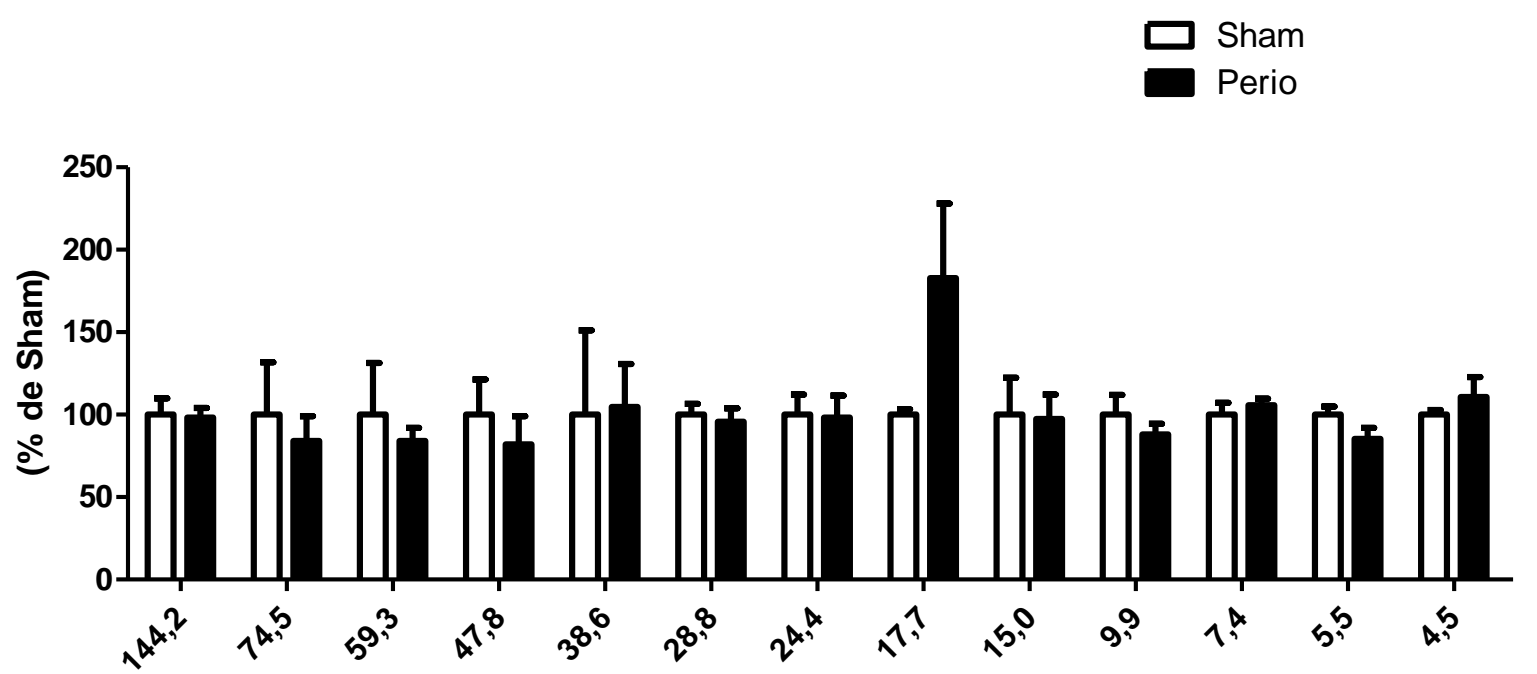

Figura 6. Proteinograma eletroforético de amostras de saliva Eletroforese de amostras de saliva obtidas após 3 dias da indução da doença periodontal ou da simulação do procedimento $(n=3-4)$. Painel A: figura representativa do perfil eletroforético obtido das amostras (S: amostras de animais Sham, P: amostras de animais com doença periodontal, MW: padrões de calibração de peso molecular). Painel B: análise densitométrica das bandas presentes, expressas em unidades arbitrárias. Os dados foram plotados como média‡EPM para cada grupo e analisados pelo teste $t$ não pareado. Não foram observadas diferenças significativas em relação ao grupo Sham $(P>0,05)$. 
A.

\section{Proteinograma 7 dias}

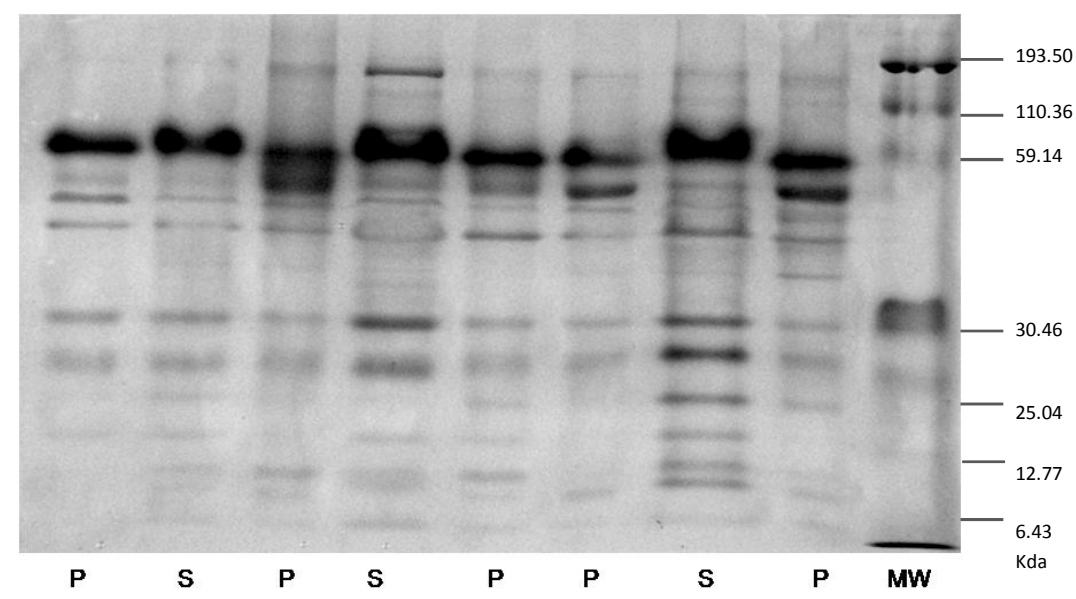

B.

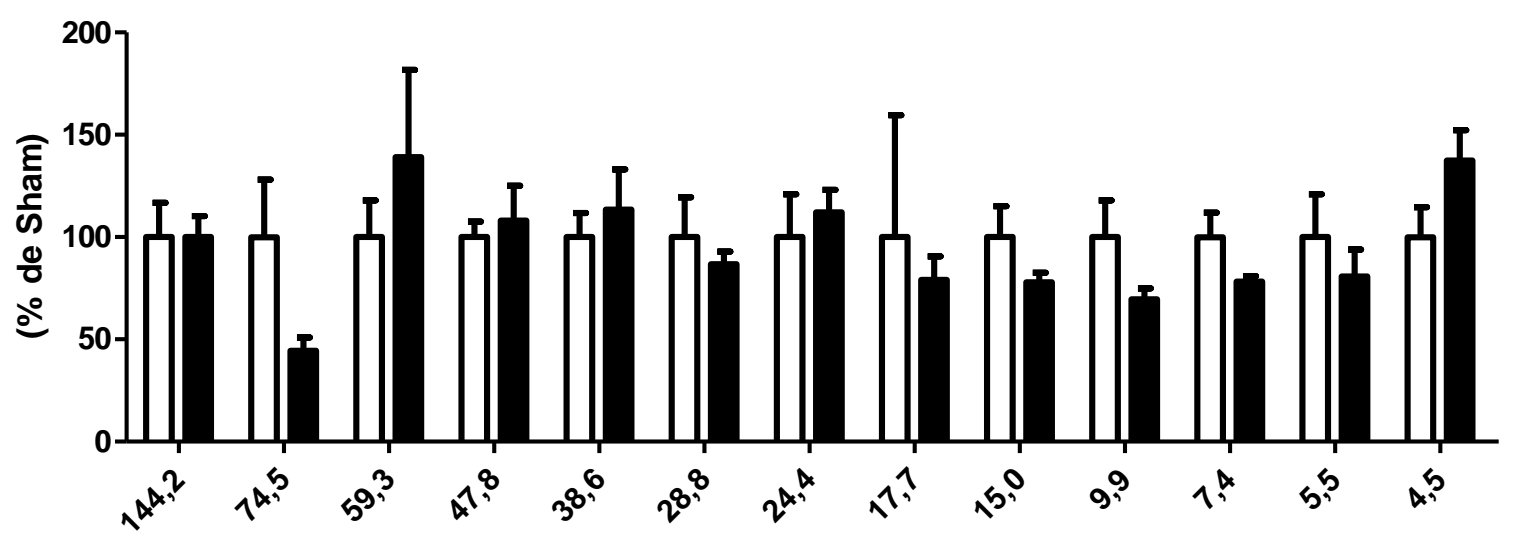

Figura 7. Proteinograma eletroforético de amostras de saliva Eletroforese de amostras de saliva obtidas após 7 dias da indução da doença periodontal ou da simulação do procedimento ( $n=3$ 4). Painel A: figura representativa do perfil eletroforético obtido das amostras (S: amostras de animais Sham, P: amostras de animais com doença periodontal, MW: padrões de calibração de peso molecular). Painel B: análise densitométrica das bandas presentes, expressas em unidades arbitrárias. Os dados foram plotados como média土EPM para cada grupo e analisados pelo teste $t$ não pareado. Não foram observadas diferenças significativas em relação ao grupo Sham $(P>0,05)$. 


\section{Proteinograma 14 dias}

A.

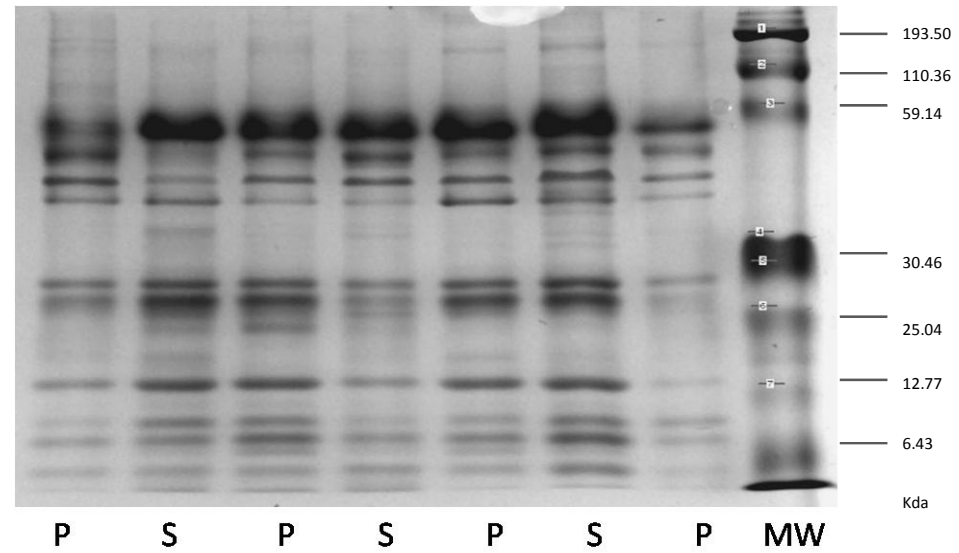

B.

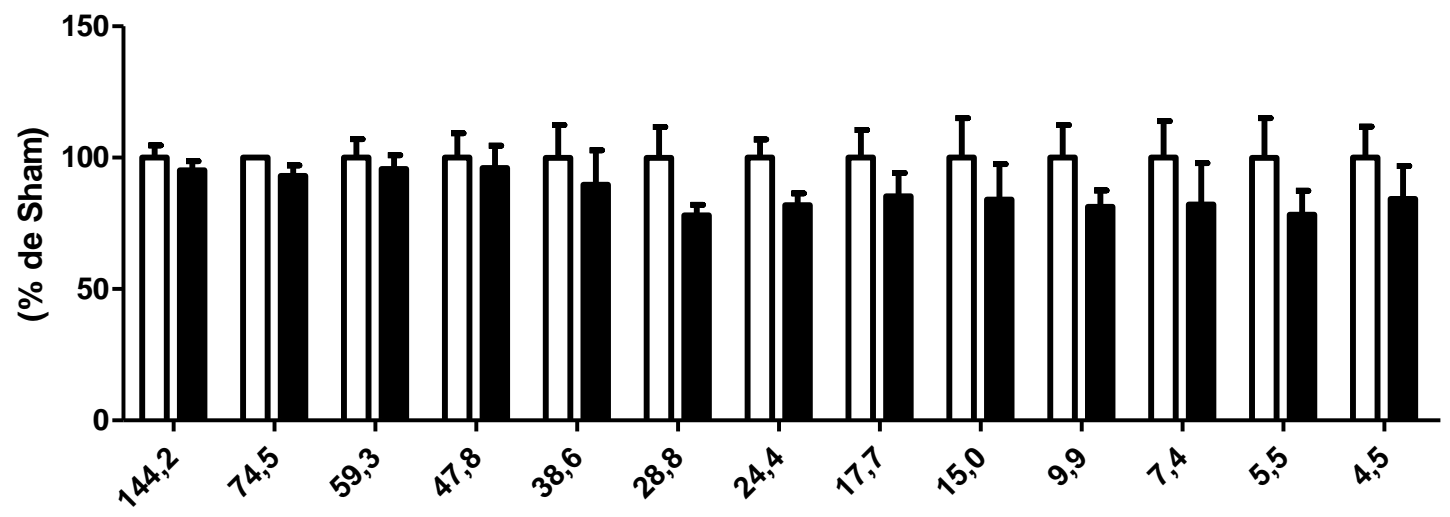

Figura 8. Proteinograma eletroforético de amostras de saliva Eletroforese de amostras de saliva obtidas após 14 dias da indução da doença periodontal ou da simulação do procedimento $(n=3-4)$. Painel A: figura representativa do perfil eletroforético obtido das amostras ( $\mathrm{S}$ : amostras de animais Sham, P: amostras de animais com doença periodontal, MW: padrões de calibração de peso molecular). Painel B: análise densitométrica das bandas presentes, expressas em unidades arbitrárias. Os dados foram plotados como média土EPM para cada grupo e analisados pelo teste $t$ não pareado. Não foram observadas diferenças significativas em relação ao grupo Sham $(P>0,05)$. 


\subsection{Amilase salivar}

A concentração, taxa de secreção e atividade específica de amilase foram analisadas nas amostras de saliva obtidas após indução da doença periodontal ou da simulação do procedimento.

Após 3 dias do implante da ligadura, não foram observadas diferenças entre os grupos com relação à concentração salivar de amilase (Figura 9, painel $A ; 100 \pm 8.6$ vs. $121 \pm 12,3 \%$ de Sham), ou à sua atividade específica (Figura 9, painel C; $100 \pm 6,8$ vs. $83,1 \pm 6.5 \%$ de Sham). Entretanto, a taxa de secreção salivar apresentou-se aumentada nos animais do grupo periodontite em relação aos animais que passaram pelo procedimento simulado (Figura 9, painel $B ; 100 \pm 6,8$ vs. $155,7 \pm 16,3 \%$ de Sham, $p<0.05$ vs. Sham).

Após 7 dias do implante da ligadura, as amostras de saliva dos animais com periodontite induzida mostraram uma diminuição quanto à concentração salivar de amilase (Figura 10 , painel $A ; 100 \pm 4,5$ vs. $80,8 \pm 4,63 \%$ de Sham, $p<0.05$ vs. Sham) e com relação à

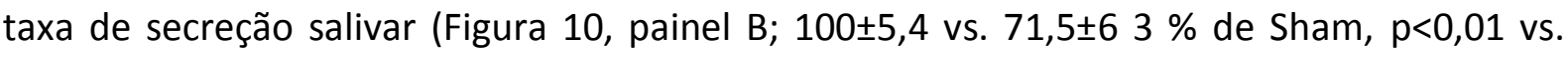
Sham), já com relação à sua atividade específica, não foram observadas diferenças significativas (Figura 10, painel C; $100 \pm 10,6$ vs.92,8 $\pm 7,3 \%$ de Sham).

Aos 14 dias de indução da doença, não foram observadas diferenças entre os grupos com relação à concentração salivar de amilase (Figura 11, painel A; $100 \pm 4,7$ vs. $96,4 \pm 4 \%$ de

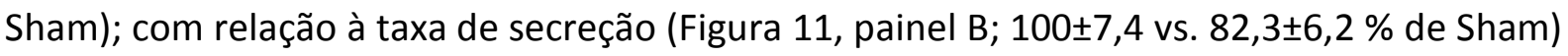
e com relação à sua atividade específica (Figura 11, painel C; $100 \pm 8,1$ vs. $90,8 \pm 5,1 \%$ de Sham). 
A.



B.

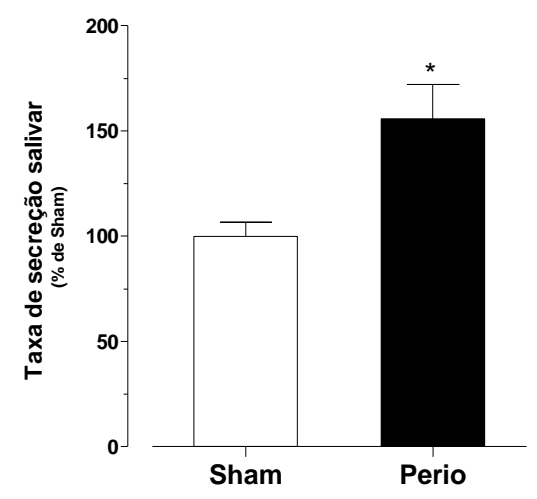

c.

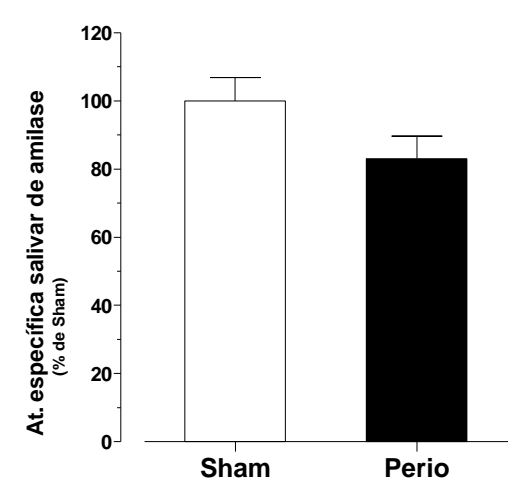

Figura 9. Mensuração salivar de amilase. Foram analisadas a concentração (painel A), taxa de secreção (painel B) e atividade específica salivar de amilase em amostras obtidas 3 dias após a indução de periodontite ou da simulação do procedimento $(n=11-12)$. Os dados foram plotados como médiatEPM para cada grupo e analisados pelo teste $t$ não pareado. ${ }^{*}(p<0,05)$, indica diferenças significativas em relação ao respectivo grupo controle - Sham. 
A.
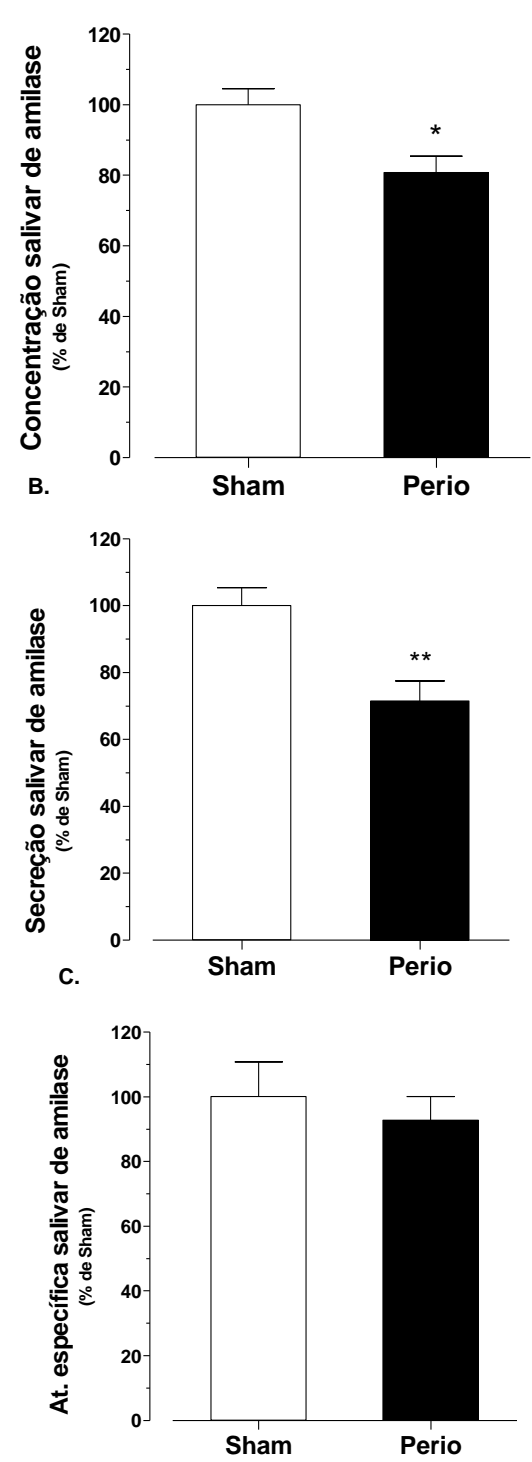

Figura 10. Mensuração salivar de amilase. Foram analisadas a concentração (painel A), taxa de secreção (painel B) e atividade específica salivar de amilase em amostras obtidas 7 dias após a indução de periodontite ou da simulação do procedimento $(n=11-12)$. Os dados foram plotados como médiatEPM para cada grupo e analisados pelo teste $\mathrm{t}$ não pareado. ${ }^{*}(p<0,05),\left({ }^{* *} p<0,01\right)$ indica diferenças significativas em relação ao respectivo grupo controle - Sham. 
A.

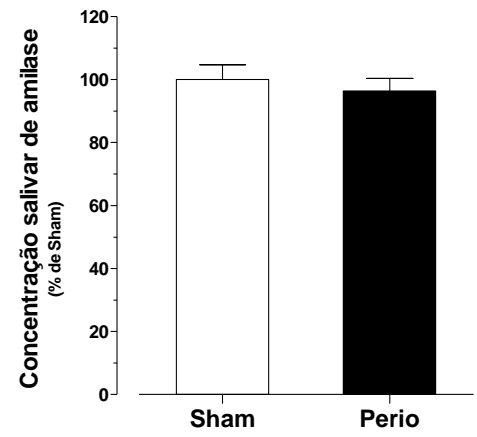

B.

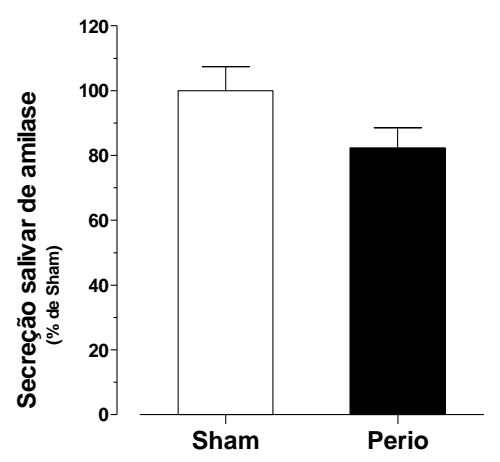

c.

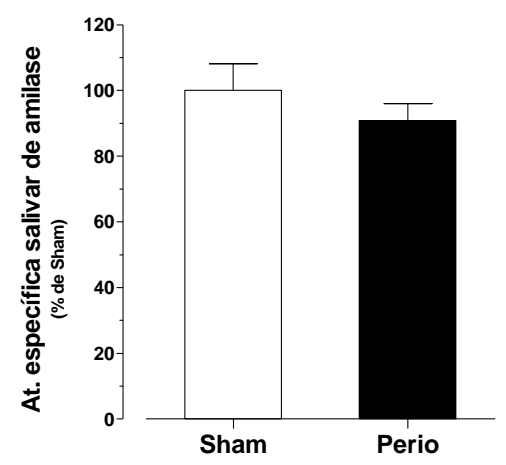

Figura 11. Mensuração salivar de amilase. Foram analisadas a concentração (painel A), taxa de secreção (painel B) e atividade específica salivar de amilase em amostras obtidas 14 dias após a indução de periodontite ou da simulação do procedimento ( $n=11-12)$. Os dados foram plotados como média土EPM para cada grupo e analisados pelo teste $t$ não pareado. Não foram observadas diferenças significativas em relação ao grupo Sham $(P>0,05)$. 
4.7 Determinação do conteúdo tecidual de produtos de reação do ácido tiobarbitúrico (TBARS)

Não foram observadas diferenças estatisticamente significativas entre os grupos experimentais quanto ao conteúdo salivar de TBARS medido após 3 dias da indução da doença (Figura 12, painel A; $100 \pm 16$ vs. $177 \pm 36 \%$ de Sham), plasmático (Figura 12, painel B; $100 \pm 3,6$ vs. $110 \pm 5 \%$ de Sham), assim como o conteúdo de TBARS em amostras de glândulas submandibulares (Figura 12, painel C; ipsilateral: $100 \pm 18$ vs. $112,3 \pm 12$; contralateral: $100 \pm 12,1$ vs. $122 \pm 11,2$ \% de Sham ). Já em amostras de glândulas parótidas, foi observado um aumento no conteúdo de TBARS nas amostras dos grupos periodontite em relação ao grupo Sham ipsilateral ao procedimento, não sendo observado tal efeito nas amostras de glândulas contralaterais (Figura 12, painel D; ipsilateral: 100 $\pm 6,4$ vs. 149,5 $\pm 8,2$; contralateral: $100 \pm 8,8$ vs. $121,3 \pm 7,2 \%$ de Sham, $p<0,001$ vs. Sham).

Aos 7 dias do implante da ligadura, foram observadas diferenças estatisticamente significativas entre os grupos experimentais quanto ao conteúdo salivar de TBARS (Figura 13, painel $A ; 100 \pm 16,5$ vs. $239 \pm 43,6 \%$ de Sham, $p<0,05)$, assim como aumento do conteúdo plasmático de TBARS em animais com periodontite em relação ao grupo Sham (Figura 13, painel B; $100 \pm 12,0$ vs. $145 \pm 4,9 \mathrm{nmol} \mathrm{MDA} / \mathrm{m}, \mathrm{p}<0,05$ vs. Sham). Já em amostras de glândulas submandibulares e em amostras de glândulas parótidas não foram observadas diferenças entre os grupos experimentais (Figura 13, painel C; ipsilateral: $100 \pm 6,3$ vs. 96,8 $\pm 7,3$; contralateral: $100 \pm 8,3$ vs. $94 \pm 4,5 \%$ de Sham ) e (Figura 13, painel D; ipsilateral: $100 \pm 11,5$ vs. $98 \pm 13.8$; contralateral: $100 \pm 8,6$ vs. $134 \pm 22,7 \%$ de Sham ), respectivamente.

Não foram observadas diferenças significativas 14 dias após o procedimento de implante de ligadura ou simulação no conteúdo de TBARS em amostras de plasma (Figura 14, painel B; $100 \pm 5$ vs. $117 \pm 12 \mathrm{nmol} \mathrm{MDA} / \mathrm{ml}$ ), glândula submandibular (Figura 14, painel C; ipsilateral: $100 \pm 10,4$ vs. $98,8 \pm 4,2$; contralateral: $100 \pm 6,6$ vs. $102,4 \pm 12,4 \%$ de Sham) e em amostras de glândula parótida (Figura 14, painel D; ipsilateral: 100 $\pm 4,6$ vs. $104 \pm 5,4$; contralateral: $100 \pm 7,7$ vs. $113 \pm 2,2 \%$ de Sham). Já em amostras de saliva foi observado um aumento no conteúdo de TBARS no grupo periodontite em relação ao grupo Sham (Figura 14 , painel $A ; 100 \pm 23$ vs. $380 \pm 51,8 \%$ de Sham, $p<0,01)$. 

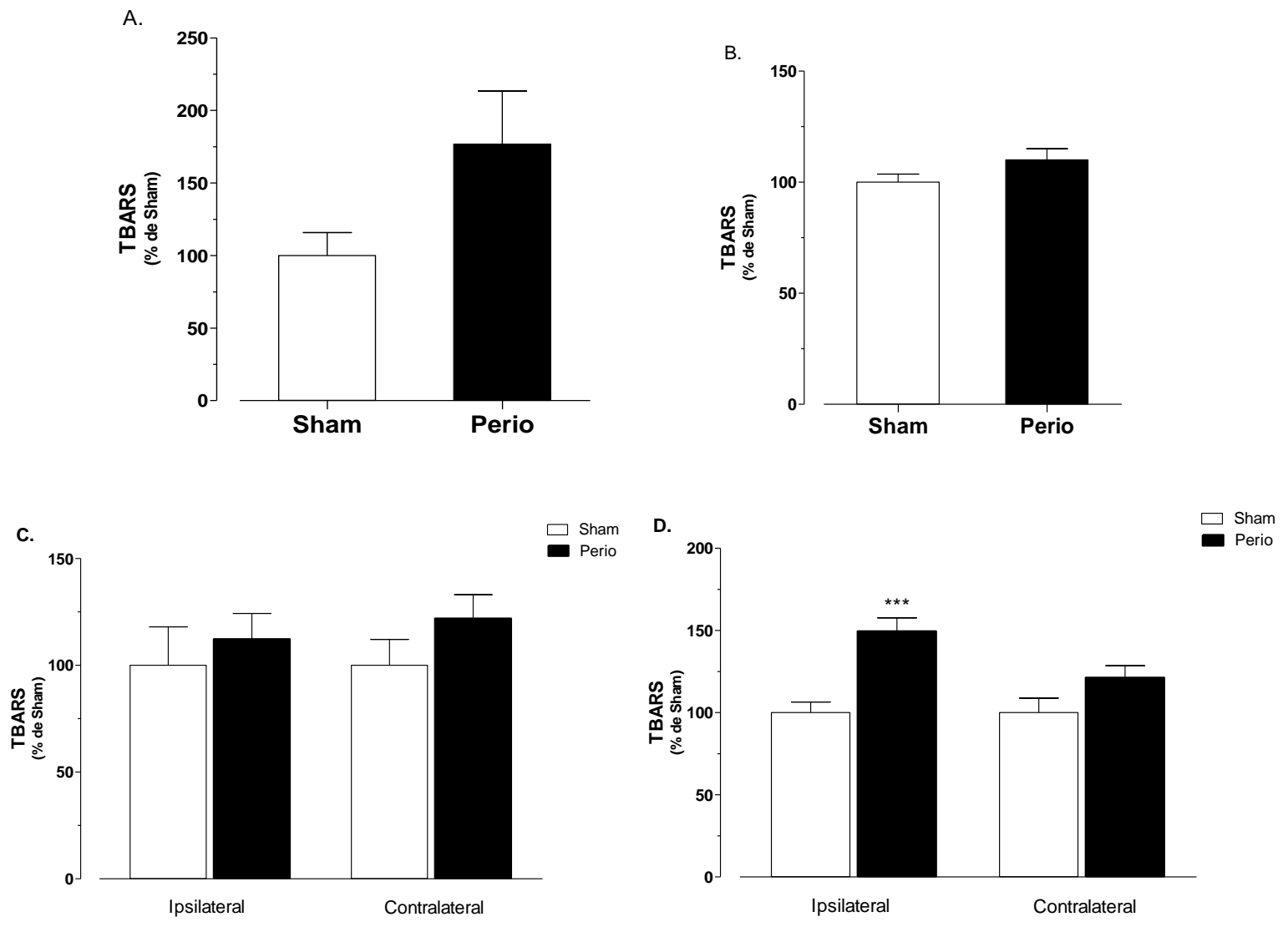

Figura 12. Determinação do conteúdo tecidual de produtos de reação do ácido tiobarbitúrico em amostras de 3 dias. $O$ conteúdo de TBARS foi determinado em amostras de saliva (painel A), plasma (painel B), glândula submandibular (painel C) e glândula parótida (Painel D) obtidas após 3 dias da indução da doença periodontal ou procedimento simulado ( $n=4-6)$. Os dados foram plotados como médiatEPM para cada grupo e analisados pelo teste $\mathrm{t}$ não pareado. ${ }^{* * *}(\mathrm{p}<0,001)$ indica diferenças significativas em relação ao respectivo grupo controle - Sham. 

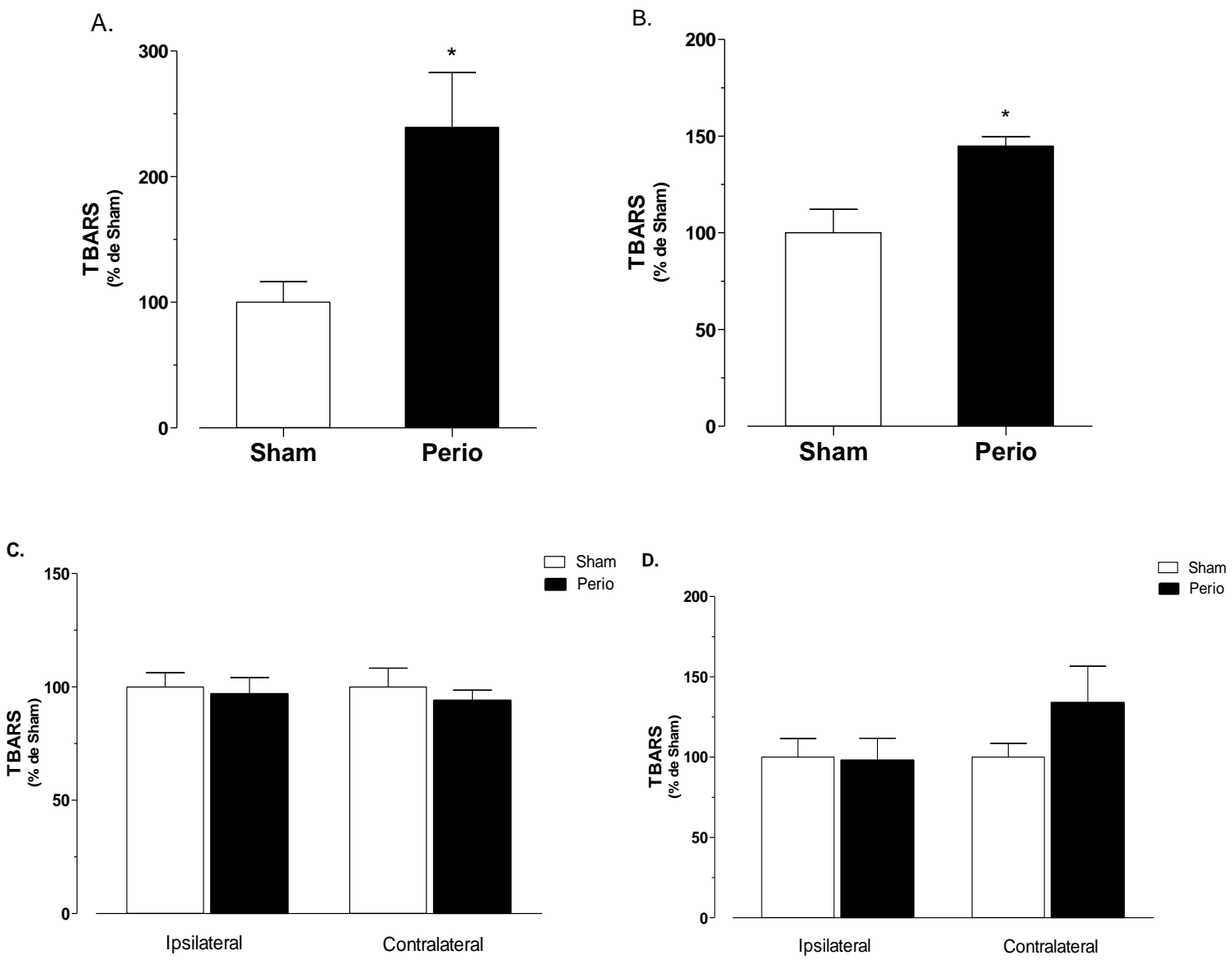

Figura 13. Determinação do conteúdo tecidual de produtos de reação do ácido tiobarbitúrico em amostras de 7 dias $O$ conteúdo de TBARS foi determinado em amostras de saliva (painel A), plasma (painel B), glândula submandibular (painel C) e glândula parótida (Painel D) obtidas após 7 dias da indução da doença periodontal ou procedimento simulado $(n=5$ 7). Os dados foram plotados como médiatEPM para cada grupo e analisados pelo teste $t$ não pareado. ${ }^{*}(p<0,05)$ indica diferenças significativas em relação ao respectivo grupo controle Sham. 
A.

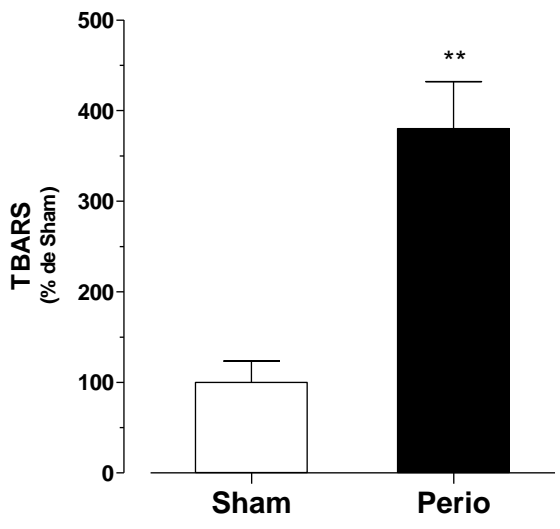

c.

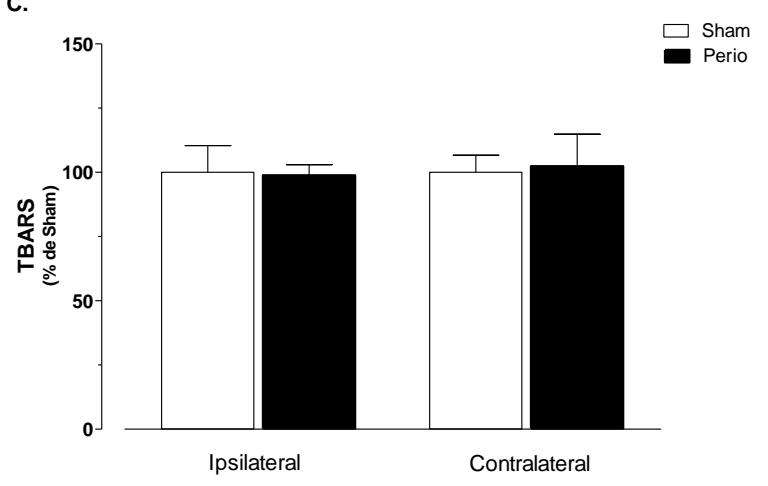

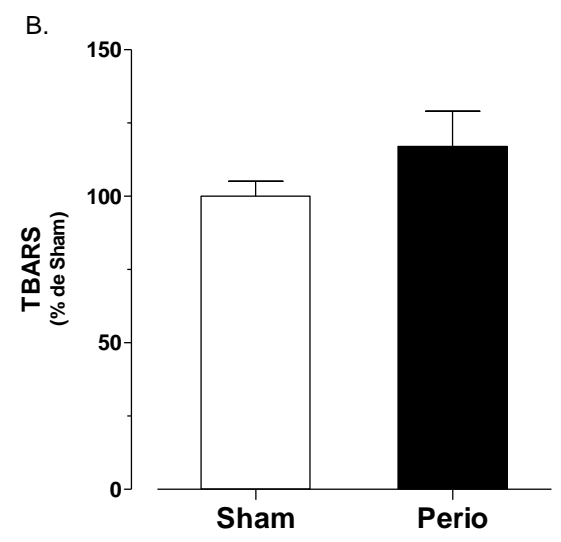

D.

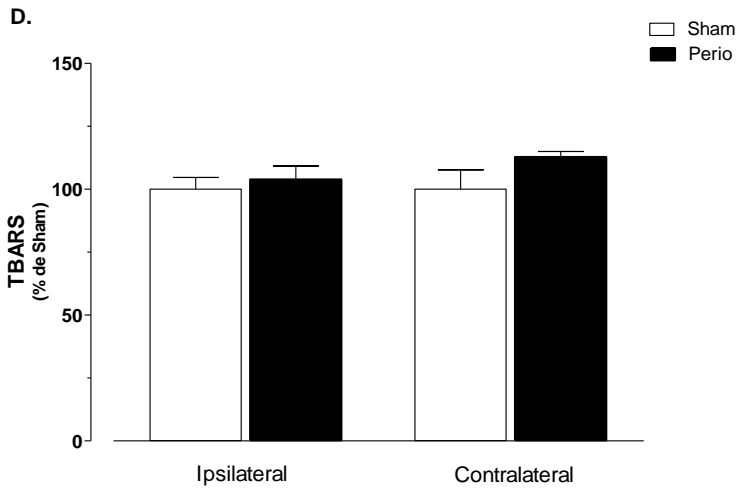

Figura 14. Determinação do conteúdo tecidual de produtos de reação do ácido tiobarbitúrico em amostras de 14 dias. O conteúdo de TBARS foi determinado em amostras de saliva (painel A), plasma (painel B), glândula submandibular (painel C) e glândula parótida (Painel D) obtidas após 14 dias da indução da doença periodontal ou procedimento simulado ( $n=3-5)$. Os dados foram plotados como médiatEPM para cada grupo e analisados pelo teste $\mathrm{t}$ não pareado. ${ }^{* *} \mathrm{p}<0,01$ indica diferenças significativas em relação ao grupo Sham. 
4.8 Íons nitrito e nitrato salivares

Não foram observadas diferenças estatisticamente significativas entre os grupos experimentais quanto as concentrações de íons nitrito + nitrato $\left(\mathrm{NO}_{\mathrm{x}}^{-}\right)$após 3 dias da indução da doença (Figura 15, painel A; $100 \pm 8$ vs. 122,5 $\pm 17,3 \%$ de Sham).

Da mesma forma, não foram observadas diferenças estatisticamente significativas entre os grupos experimentais quanto as concentrações de íons nitrito + nitrato $\left(\mathrm{NO}_{\mathrm{x}}{ }^{-}\right)$após 7dias (Figura 15, painel B; $100 \pm 8,2$ vs. $112 \pm 11,6 \%$ de Sham) da indução da doença.

Aos 14 dias do implante de ligadura, foi observado aumento na concentração salivar quanto às concentrações de íons nitrito + nitrato $\left(\mathrm{NO}_{\mathrm{x}}{ }^{-}\right)$nas amostras de saliva dos animais do grupo periodontite em relação aos animais do grupo Sham (Figura 15, painel C; $100 \pm 3,7$ vs. $124,6 \pm 9,3 \%$ de Sham, $p<0,05$ vs. Sham). 



Figura 15. Concentração de íons nitritostnitratos $\left(\mathrm{NO}_{\mathrm{x}}{ }^{-}\right)$em amostras de saliva. Mensuração realizada em amostras de saliva, obtidas após 3 (Painel A), 7 (Painel B) e 14 dias (Painel C) de indução da doença periodontal ou procedimento simulado ( $n=9-10)$. Os dados foram plotados como média \pm EPM para cada grupo e analisados pelo teste $t$ não pareado. ${ }^{*}(p<0,05)$ indica diferenças significativas em relação ao respectivo grupo controle - Sham 
4.9 Medida da atividade tecidual e salivar de mieloperoxidase (MPO) e peroxidase

Após 3 dias da indução da doença periodontal, não foram observadas diferenças estatísticas entre os grupos quanto a atividade de MPO/ peroxidase em amostras de saliva

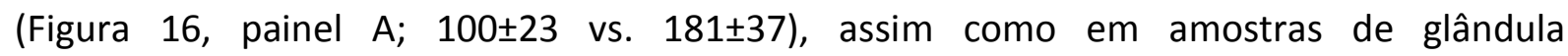
submandibular (Figura 16, painel B; Ipsilateral: 100 $\pm 59,8$ vs. 24,4 $\pm 6,5$; Contralateral: $100 \pm 52,5$ vs. $15,6 \pm 5,6$ \% de Sham) e em amostras de glândula parótida (Figura 16, painel C; Ipsilateral: $100 \pm 42,5$ vs. $82,3 \pm 47,9$; Contralateral: $100 \pm 47$ vs. $108,7 \pm 38 \%$ de Sham).

Aos 7 dias do implante de ligadura ou do procedimento simulado, a atividade de MPO/ peroxidase em amostras de saliva estava aumentada (Figura 17, painel $A ; 100 \pm 41,7$ vs. $441 \pm 83,5$ \% de Sham, $p<0,01$ ). Já em amostras de glândula submandibular (Figura 17, painel B; Ipsilateral: $100 \pm 29,5$ vs. $84 \pm 28$; Contralateral: $100 \pm 39,3$ vs. $54,5 \pm 21,2 \%$ de Sham) e em amostras de glândula parótida (Figura 17, painel C; Ipsilateral: 100 $\pm 15,3$ vs. $70 \pm 16,2$; Contralateral: $100 \pm 51$ vs. $78,5 \pm 29 \%$ de Sham) não foram observadas diferenças significativas.

Em amostras de saliva de animais que tiveram a periodontite induzida ou passaram pela simulação do processo por 14 dias a atividade de MPO/ peroxidase estava aumentada (Figura 18, painel A; $100 \pm 30,7$ vs.1734 $\pm 203 \%$ de Sham, p<0,001). Em amostras de glândula submandibular foi observado aumento nas amostras dos grupos Perio e Sham ipsilateral, não sendo observado tal efeito nas amostras de glândulas contralaterais (Figura 18, painel B; Ipsilateral: $100 \pm 47,2$ vs. $7597 \pm 3106$; Contralateral: $100 \pm 27,1$ vs. $6371 \pm 3724 \%$ de Sham, p<0,05). Em amostras de glândula parótida não foram observadas diferenças significativas entre os grupos (Figura 18, painel C; Ipsilateral: $100 \pm 23,7$ vs. $73,7 \pm 19,5$; Contralateral: $100 \pm 21,4$ vs. $71,6 \pm 28,5 \%$ de Sham). 


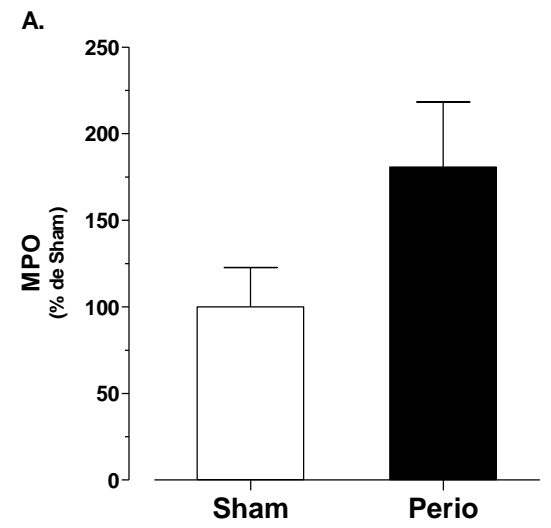

B.


Figura 16. Determinação da atividade de MPO/ peroxidase salivar. Foram analisadas amostras de saliva (Painel A), de glândula submandibular (Painel B) e glândula parótida (Painel C) obtidas 3 dias após a indução da doença periodontal ou procedimento simulado $(n=5-6)$. Os dados foram plotados como médiatEPM para cada grupo e analisados pelo teste $t$ não pareado. Não foram observadas diferenças significativas em relação ao grupo Sham $(P>0,05)$. 
A.

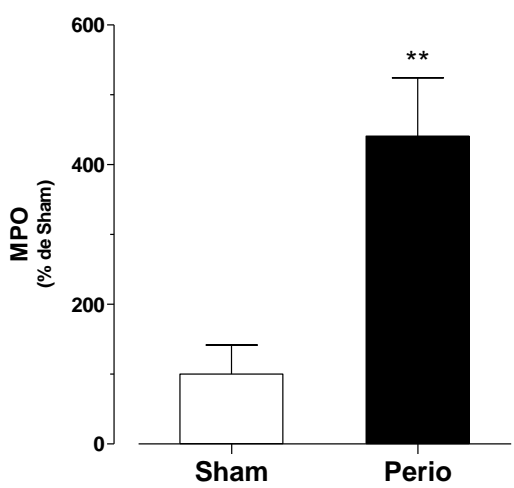

B.

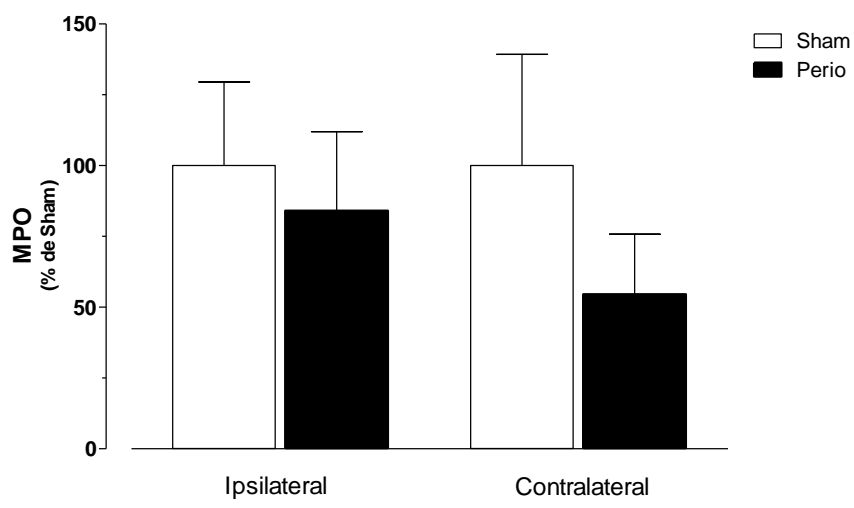

c.

$\square$ Sham

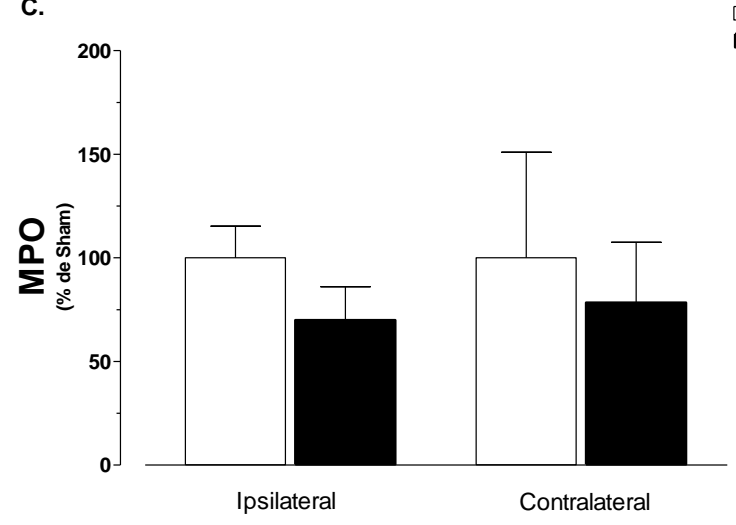

Figura 17. Determinação da atividade de MPO/ peroxidase salivar. Foram analisadas amostras de saliva (Painel A), de glândula submandibular (Painel B) e glândula parótida (Painel C) obtidas 7 dias após a indução da doença periodontal ou procedimento simulado ( $n=5-6)$. Os dados foram plotados como média士EPM para cada grupo e analisados pelo teste $t$ não pareado. ** $p<0,01$ indica diferenças significativas em relação ao respectivo grupo controle - Sham. 

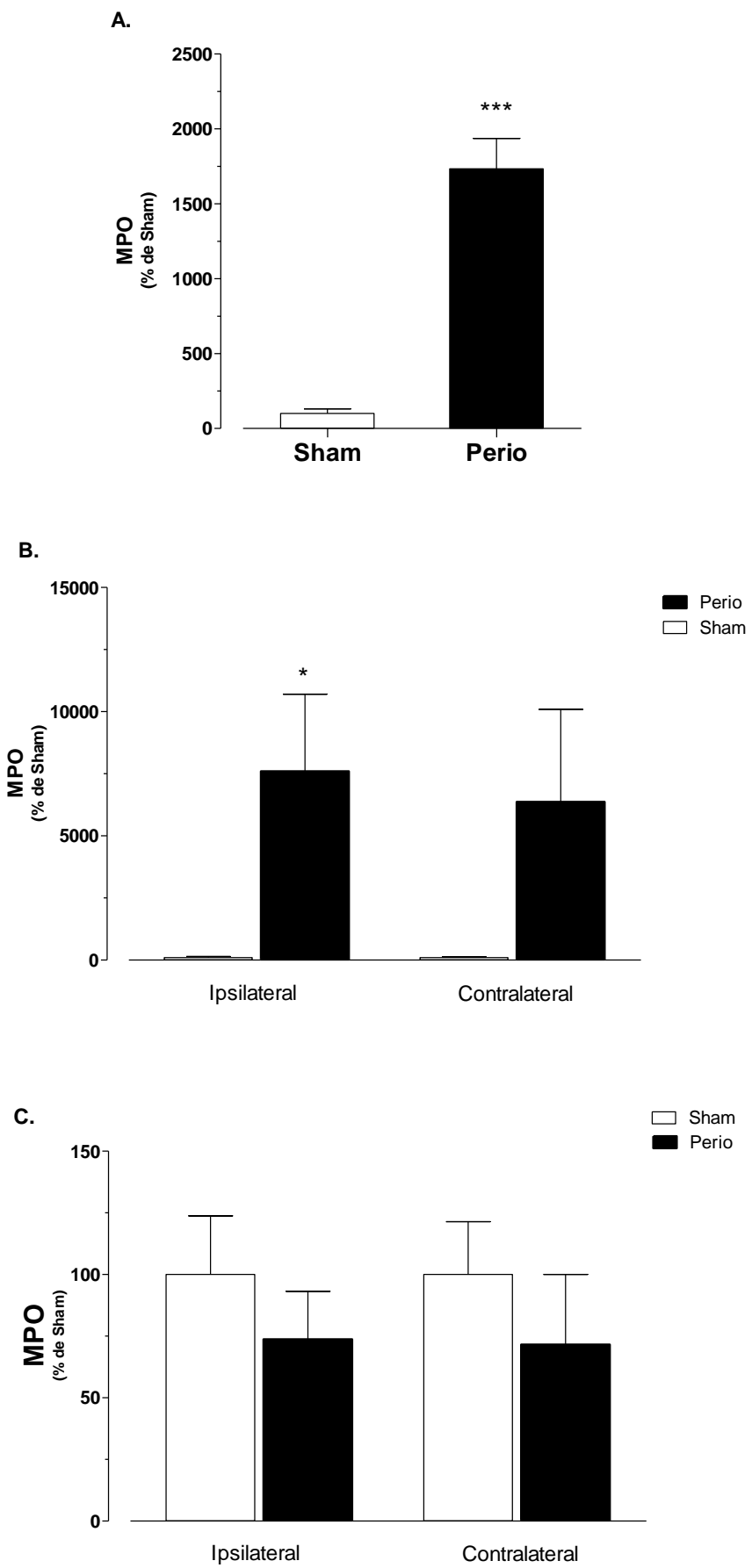

Figura 18. Determinação da atividade de MPO/ peroxidase salivar. Foram analisadas amostras de saliva (Painel A), de glândula submandibular (Painel B) e glândula parótida (Painel C) obtidas 14 dias após a indução da doença periodontal ou procedimento simulado $(n=5$ 6). Os dados foram plotados como média \pm EPM para cada grupo e analisados pelo teste $t$ não pareado. ${ }^{* * *}(p<0,001) e^{*}(p<0,05)$ indicam diferenças significativas em relação ao respectivo grupo controle - Sham. 


\subsection{Análise de resíduos protéicos de nitrotirosina}

Os resultados de análise de resíduos protéicos de nitrotirosina presentes em amostras de glândula submandibular (GSM) após 3 dias da indução da doença periodontal estão representados na Figura 19. O Painel A mostra imagem representativa dos dados obtidos no experimento. No painel $B$, observa-se o gráfico da análise densitométrica da banda nitrada (em unidades arbitrárias), usando-se a análise densitométrica das proteínas totais coradas com vermelho de Ponceau como fator normalizador. Após 3 dias da indução da doença periodontal, as amostras de glândulas de animais com periodontite, tanto do lado ipsilateral, quanto do lado contralateral ao procedimento não apresentaram diferenças significativas (Ipsilateral: $100 \pm 13,3$ vs. $84,7 \pm \pm 6,8$; Contralateral: $100 \pm 13,6$ vs. $116,7 \pm 3,7 \%$ de Sham).

Na Figura 20 vemos a representação dos dados de análise de resíduos protéicos de nitrotirosina, detectados por slot blot presentes em amostras de glândula submandibular (GSM) de animais 7 dias após a indução da doença. O Painel A mostra imagem representativa dos dados obtidos no slot blot (painel A). Já o Painel B mostra a análise densitométrica da banda nitrada (em unidades arbitrárias) usando a análise densitométrica das proteínas totais coradas com vermelho de Ponceau como fator normalizador. Após 7 dias da indução da doença periodontal, não foram observadas diferenças significativas entre os grupos (Ipsilateral: $100 \pm 14,9$ vs. $112,3 \pm 13,9$; Contralateral: $100 \pm 10,9$ vs. $130 \pm 15,81 \%$ de Sham).

Na Figura 21 encontram-se dados de análise de resíduos protéicos de nitrotirosina, detectados por slot blot presentes em amostras de glândula submandibular (GSM) de animais 14 dias após a indução da doença. O Painel A mostra imagem representativa dos dados obtidos no slot blot. Já o Painel B mostra a análise densitométrica da banda nitrada (em unidades arbitrárias) usando-se a análise densitométrica das proteínas totais coradas com vermelho de Ponceau como fator normalizador. Após 14 dias da indução da doença periodontal, as amostras de glândulas de animais com periodontite do lado ipsilateral ao procedimento estavam aumentadas em relação ao grupo Sham (Ipsilateral: $100 \pm 7,4$ vs. $142,8 \pm 13,7,2$; Contralateral: $100 \pm 5,6$ vs. $94,5 \pm 7,9 \%$ de Sham, $p<0,05)$. 
A.

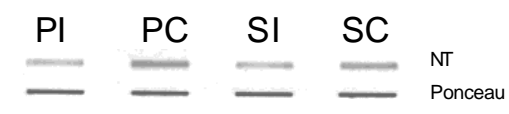

B.
NT 3 dias
$\square$ Sham
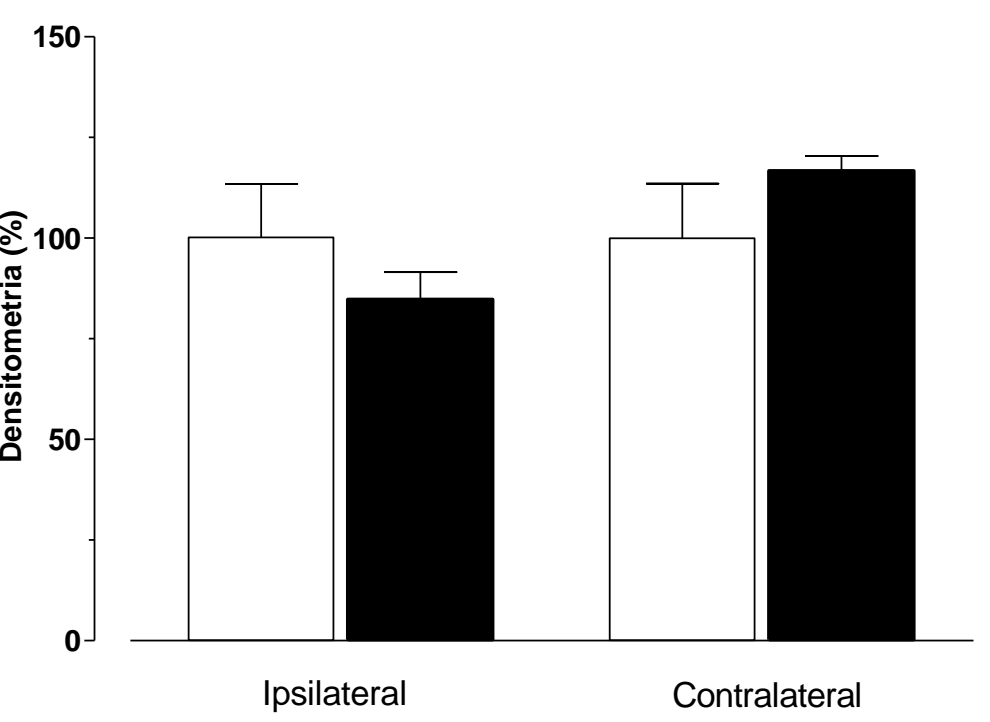

Figura 19. Análise de resíduos protéicos de nitrotirosina, detectados por slot blot presentes em glândula submandibular (GSM). Amostras obtidas após 3 dias da indução da doença periodontal ou procedimento simulado( $n=4-5)$. Imagem representativa dos dados obtidos no slot blot (painel A - PI- Periodontite Ipsilateral; PC- Periodontite Contralateral; SI- Sham Ipsilateral; SC- Sham Contralateral ). O gráfico acima (painel B) representa a análise densitométrica da banda nitrada (em unidades arbitrárias) usando a análise densitométrica das proteínas totais coradas com vermelho de Ponceau como fator normalizador. Os dados foram plotados como médiatEPM para cada grupo e analisados pelo teste $t$ não pareado. Não foram observadas diferenças significativas em relação ao grupo Sham $(P>0,05)$. 

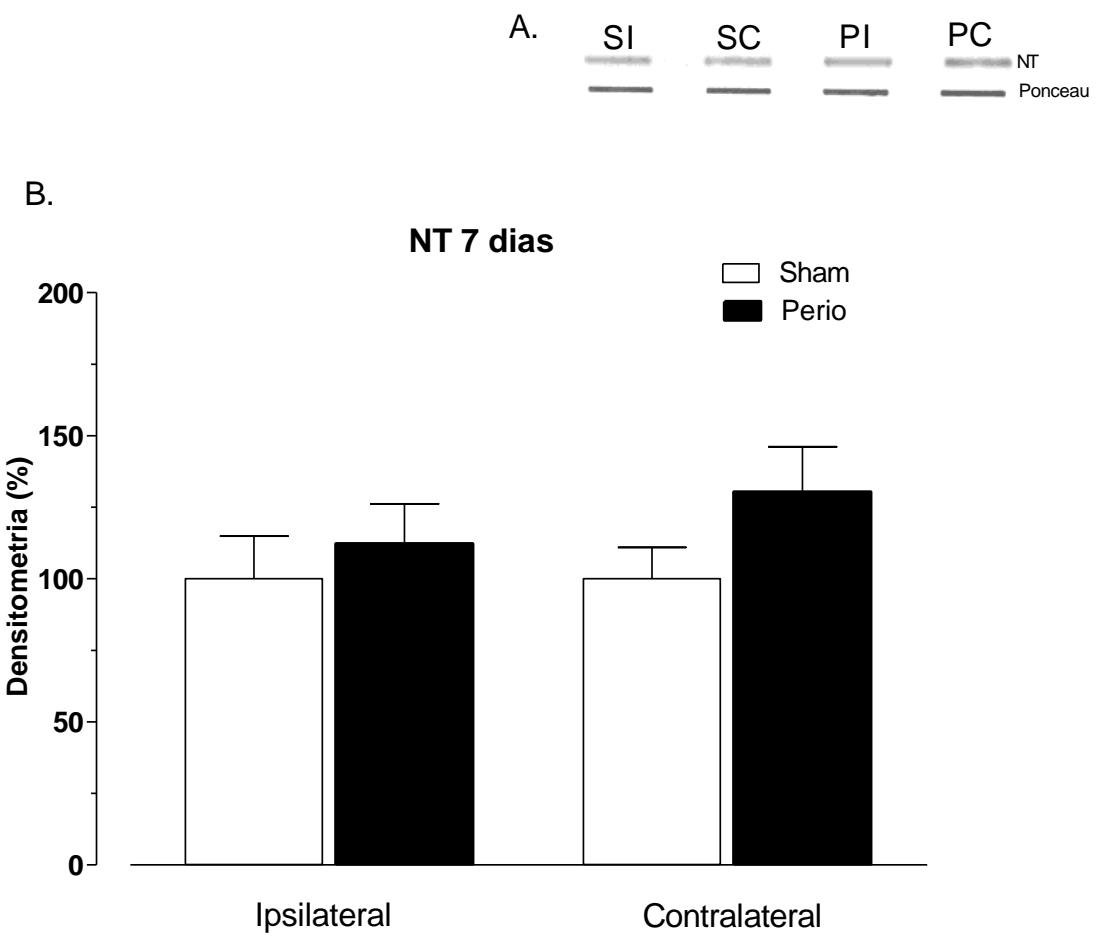

Figura 20. Análise de resíduos protéicos de nitrotirosina, detectados por slot blot presentes em glândula submandibular (GSM). Amostras obtidas após 7 dias da indução da doença periodontal ou procedimento simulado( $n=4-5)$. Imagem representativa dos dados obtidos no slot blot (Painel A - PI- Periodontite Ipsilateral; PC- Periodontite Contralateral; SI- Sham Ipsilateral; SC- Sham Contralateral). O gráfico acima (Painel B) representa a análise densitométrica da banda nitrada (em unidades arbitrárias) usando a análise densitométrica das proteínas totais coradas com vermelho de Ponceau como fator normalizador. Os dados foram plotados como médiatEPM para cada grupo e analisados pelo teste $t$ não pareado. Não foram observadas diferenças significativas em relação ao grupo Sham $(P>0,05)$. 
A.

B.
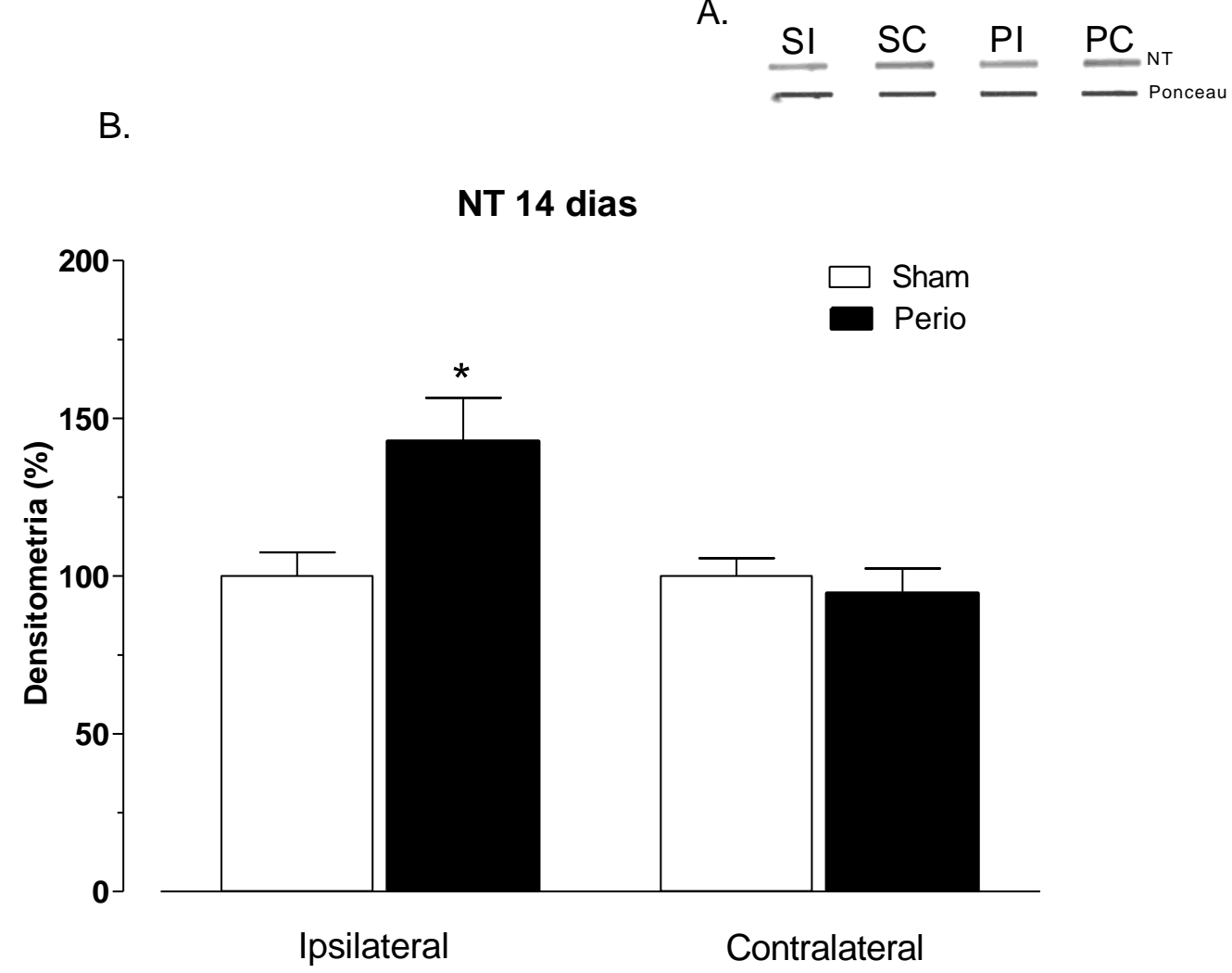

Figura 21. Análise de resíduos protéicos de nitrotirosina, detectados por slot blot presentes em glândula submandibular (GSM). Amostras obtidas após 14 dias da indução da doença periodontal ou procedimento simulado( $n=4-5)$. Imagem representativa dos dados obtidos no slot blot (Painel A - PI- Periodontite Ipsilateral; PC- Periodontite Contralateral; SI- Sham Ipsilateral; SC- Sham Contralateral). O gráfico acima (Painel B) representa a análise densitométrica da banda nitrada (em unidades arbitrárias) usando a análise densitométrica das proteínas totais coradas com vermelho de Ponceau como fator normalizador. Os dados foram plotados como média \pm EPM para cada grupo e analisados pelo teste $\mathrm{t}$ não pareado. ${ }^{*}(\mathrm{p}<0.05)$, indica diferenças significativas em relação ao grupo Sham. 
4.11 Atividade funcional "ex vivo" de glândulas submandibulares e sublinguais

Aos 3 dias foi observado aumento da atividade de amilase em amostras de glândula submandibular no lado contralateral à indução da doença (Figura 22, Painel A; Ipsilateral: $100 \pm 7,6$ vs. $123,2 \pm 18,75$; Contralateral: $100 \pm 9,2$ vs. $164,3 \pm 38,5 \%$ de Sham, $p<0,05$ )

Aos 7 dias foi observada diminuição da atividade de amilase em amostras de glândula submandibular no lado ipsilateral ao implante da ligadura (Figura 22, Painel B; Ipsilateral: $100 \pm 15$ vs. $47 \pm 14,7$; Contralateral: $100 \pm 10,6$ vs. $156 \pm 26,4 \%$ de Sham, $p<0,05$ )

Aos 14 dias de indução da doença não foram observadas diferenças estatísticas entre os grupos Sham e Perio, lados ipsilateral e contralateral, quanto à quantida de de amilase em amostras de glândulas submandibulares e sublinguais (Figura 22, Painel C; Ipsilateral: $100 \pm 15,3$ vs. $73,3 \pm 29,6$; Contralateral: $100 \pm 30,4$ vs. $45,2 \pm 13,2 \%$ de Sham) 



Figura 22. Medida da concentração de amilase liberada por GSM ex-vivo. Concentração de amilase em amostras de GSM após 3 dias da indução da doença ou da simulação do procedimento $(n=4-5)$. Os dados foram plotados como média \pm EPM para cada grupo e analisados pelo teste $\mathrm{t}$ não pareado. ${ }^{*}(\mathrm{p}<0.05)$, indica diferenças significativas em relação ao grupo Sham. 
4.12 Dosagem de citocinas em amostras de glândulas submandibulares (GSM)

Aos 3 dias do implante de ligadura, houve aumento dos níveis de TNF- $\alpha$ em amostras de animais com periodontite em relação ao grupo Sham (Periodontite: $231 \pm 76,1$ vs. Sham $100 \pm 7 \%$ de Sham, $p<0,05)$. Os níveis das demais citocinas não foram alterados pela indução de periodontite em amostras de glândulas submandibulares (Tabela 2).

Aos 7 dias de indução da doença, não foi observada alteração na quantidade de citocinas liberadas das glândulas submandibulares do grupo periodontite em relação ao grupo Sham (Tabela 3).

Após 14 dias do implante da ligadura observamos aumento de IL4 $(p<0.05)$, e IL13 $(p<0,01)$ no grupo que recebeu a ligadura em relação ao grupo Sham (Tabela 4). 
Tabela 2 - Análise das citocinas encontradas em glândulas submandibulares. Após 3 dias da indução da doença periodontal.

\begin{tabular}{l|l|l}
\hline & \multicolumn{2}{|c}{3 dias } \\
\hline INF-Y & $100 \pm 18,3(n=4)$ & $100,5 \pm 16,8(n=4)$ \\
\hline IL-13 & $100 \pm 32,2(n=5)$ & $61,8 \pm 20,4(n=4)$ \\
\hline IL-10 & $100 \pm 37,1(n=5)$ & $83,8 \pm 25,6(n=5)$ \\
\hline IL-4 & $100 \pm 22,3(n=4)$ & $96,3 \pm 23,7(n=4)$ \\
\hline TNF & $100 \pm 7(n=5)$ & $231 \pm 76,1(n=4)(p<0.05)$ \\
\hline IL6 & $100 \pm 12,5(n=5)$ & $68,7 \pm 4,0(n=4)$ \\
\hline IL1 $\beta$ & $100 \pm 10,2(n=6)$ & $72,4 \pm 9,1(n=4)$ \\
\hline
\end{tabular}

Tabela 3 - Análise das citocinas encontradas em glândulas submandibulares. Após 7 dias da indução da doença periodontal.

\begin{tabular}{l|l|l}
\hline & \multicolumn{2}{|c}{7 dias } \\
\hline & \multicolumn{1}{|c}{ Sham } & \multicolumn{1}{c}{ Perio } \\
\hline INF-ץ & $100 \pm 3,8(n=3)$ & $114,3 \pm 9,7(n=4)$ \\
\hline IL-10 & $100 \pm 4,8(n=4)$ & $104,5 \pm 5,3(n=4)$ \\
\hline IL-4 & $100(n=1))$ & $65,2 \pm 6,5(n=4)$ \\
\hline TNF & $100,0 \pm 23,3(n=4)$ & $122,8 \pm 55,1(n=4)$ \\
\hline IL6 & $100 \pm 9,6(n=4)$ & $119,6 \pm 15,9(n=4)$ \\
\hline IL1 $\beta$ & $100 \pm 5,8(n=4)$ & $102,4 \pm 8,7(n=4)$ \\
\hline
\end{tabular}


Tabela 4 - Análise das citocinas encontradas em glândulas submandibulares. Após 14 dias da indução da doença periodontal.

\begin{tabular}{l|l|l}
\hline \multirow{2}{*}{} & \multicolumn{2}{|c}{14 dias } \\
\hline INF-ץ & \multicolumn{1}{|c}{ Sham } & \multicolumn{1}{c}{ Perio } \\
\hline IL-13 & $100 \pm 18,4(n=4)$ & $177 \pm 31,34(n=4)$ \\
\hline IL-10 & $100 \pm 41,8(n=2)$ & $172,4 \pm 8,7(n=3)$ \\
\hline IL-4 & $100 \pm 27,4(n=4)$ & $203,6 \pm 33,9(n=4) \quad(p<0,05)$ \\
\hline IL-5 & $100 \pm 24,76(n=5)$ & $57 \pm 1,2(n=5)$ \\
\hline TNF & $100,2 \pm 32,8(n=5)$ & $140 \pm 23,5(n=4)$ \\
\hline IL6 & $100 \pm 11,79 n=5)$ & $105 \pm 12,9(n=5)$ \\
\hline IL1 $\beta$ & $100 \pm 13,2(n=5)$ & $99 \pm 9,05(n=5)$ \\
\hline
\end{tabular}




\subsection{Medida da atividade de óxido nítrico sintase}

Na Figura 23, observa-se que, após 3 dias da indução da doença periodontal, em amostras de glândula submandibular, as atividades das enzimas NOS constitutiva- $\mathrm{Ca}^{2+}$ dependente (Painel A; Ipsilateral: $100 \pm 7,7$ vs. $135 \pm 18$; Contralateral: $100 \pm 5$ vs. $93 \pm 7 \%$ de Sham) e iNOs- $\mathrm{Ca}^{2+}$ independente (Painel B; Ipsilateral: $100 \pm 5$ vs. $95 \pm 2$; Contralateral: $100 \pm 4$ vs. $132 \pm 22 \%$ de Sham), não estavam alteradas nos animais do grupo Perio com relação ao grupo Sham, ocorrendo tanto em lado ipsilateral, quanto contralateral.

Na figura observa-se também que, 7 dias após indução da doença periodontal, as amostras de glândula submandibular de animais do grupo periodontite não houve aumento com relação às atividades das enzimas NOS $-\mathrm{Ca}^{2+}$ dependente (Painel C; Ipsilateral: $100 \pm 18$ vs. $62 \pm 3,8$ Contralateral: $100 \pm 1,3$ vs. $116,56 \pm 11,3 \%$ de Sham) e NOs- $\mathrm{Ca}^{2+}$ independente (Painel D; Ipsilateral: $100 \pm 2$ vs. $112 \pm 10 ; 5$ Contralateral: $100 \pm 6,1$ vs. $97 \pm 12,1 \%$ de Sham) quando comparadas ao grupo Sham.

Após 14 dias da indução da doença periodontal as atividade das enzimas NOS

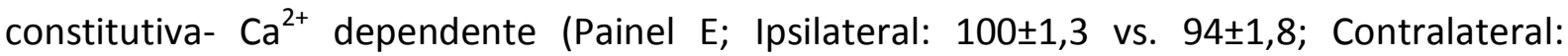
$100 \pm 1,2$ vs. $90 \pm 3 \%$ de Sham, $p<0.05$ vs. Sham) estavam diminuídas no lado ipsilateral em relação ao grupo Sham; não sendo observada alteração com relação à atividade de iNOs$\mathrm{Ca}^{2+}$ independente (Painel F; Ipsilateral: $100 \pm 1,4$ vs. $105 \pm 3,6$; Contralateral: $100 \pm 2,3$ vs. $102 \pm 1,7 \%$ de Sham). 



Figura 23. Medida da atividade de óxido nítrico sintase em glândula submandibular (GSM). Amostras obtidas após 3 (Painéis A e B), 7 (Painéis $C$ e D) e 14 dias (Painéis E e F) após a indução da doença periodontal ou procedimento simulado $(n=4-5)$. As atividades das NOS dependente e independente de $\mathrm{Ca}^{2+}$ foram expressas como \% de Sham. Os dados foram plotados como médiatEPM para cada grupo e analisados pelo teste $t$ não pareado. ${ }^{*}(p<0.05)$, indica diferenças significativas em relação ao respectivo grupo controle - Sham. 
$\mathrm{Na}$ figura 24, observa-se que, após 3 dias da indução da doença periodontal, em amostras de glândula parótida, as atividades das enzimas NOS constitutiva- $\mathrm{Ca}^{2+}$ dependente (Painel A; Ipsilateral: $100 \pm 2,2$ vs. $118 \pm 17,9$; Contralateral: $100 \pm 20$ vs.97 $\pm 12,7 \%$ de Sham) e iNOs- $\mathrm{Ca}^{2+}$ independente (Painel B; Ipsilateral: $100 \pm 7,5$ vs. $85 \pm 3$; Contralateral: $100 \pm 4$ vs.97 $\pm 2 \%$ de Sham), não estavam alteradas nos animais do grupo Perio com relação ao grupo Sham, ocorrendo tanto em lado ipsilateral, quanto contralateral.

Na mesma figura, observa-se que, após 7 dias da indução da doença periodontal, em amostras de glândula parótida, a atividade das enzimas NOS $\mathrm{Ca}^{2+}$ dependente (Painel C; Ipsilateral: $100 \pm 0,2$ vs. $108 \pm 5,4$; Contralateral: $100 \pm 2$ vs.141 $\pm 3,7 \%$ de Sham $p<0,001$ ) estavam aumentadas no grupo periodontite no lado contralateral, em relação ao grupo Sham, já a atividade de NOs- $\mathrm{Ca}^{2+}$ independente (Painel D; Ipsilateral: $100 \pm 23,4 \mathrm{vs}$. 4,9 $\pm 4,9$; Contralateral: $100 \pm 13$ vs.90 $467 \%$ de Sham, $p<0,01$ ), estava diminuída nas amostras dos animais do grupo Perio com relação ao grupo Sham, no lado ipsilateral.

Após 14 dias de indução da doença periodontal, em amostras de glândula parótida, as atividades das enzimas NOS constitutiva- $\mathrm{Ca}^{2+}$ dependente (Painel E; Ipsilateral: $100 \pm 0,2$ vs.101 $\pm 0,9$; Contralateral: $100 \pm 2,2$ vs.98 $\pm 0,2 \%$ de Sham) e iNOs- $\mathrm{Ca}^{2+}$ independente (Painel F; Ipsilateral: $100 \pm 7,8$ vs. $91 \pm 7$; Contralateral: $100 \pm 7$ vs.99 $\pm 10 \%$ de Sham), não estavam alteradas nos animais do grupo Perio com relação ao grupo Sham, ocorrendo tanto em lado ipsilateral, quanto contralateral. 

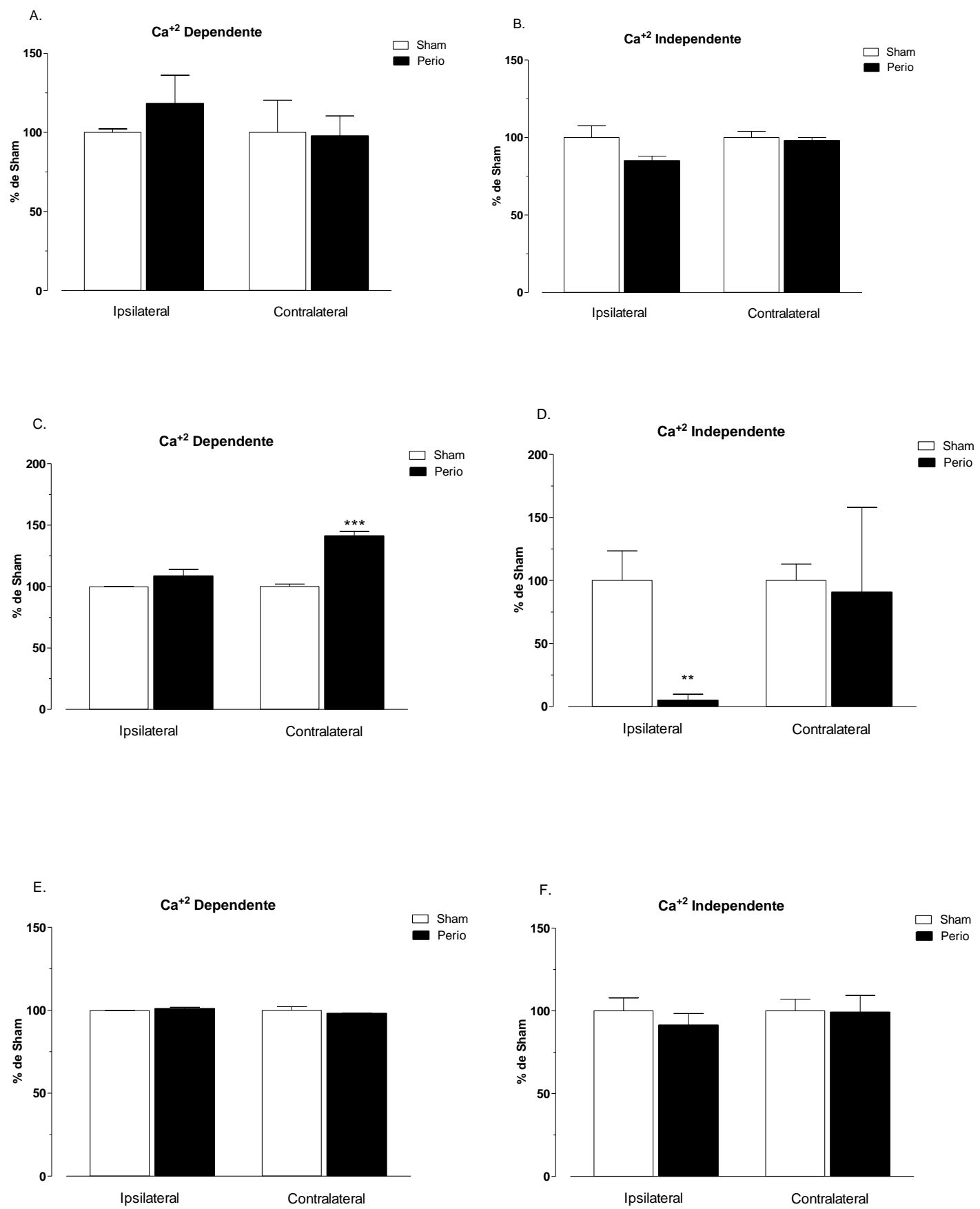

Figura 24. Medida da atividade de óxido nítrico sintase em glândula parótida. Amostras obtidas após 3 (Painéis $A$ e B), 7 (Painéis $C$ e D) e 14 dias (Painéis E e F) após a indução da doença periodontal ou procedimento simulado $(n=4-7)$. As atividades das NOS dependente e independente de $\mathrm{Ca}^{2+}$ foram expressas como \% de Sham Os dados foram plotados como média \pm EPM para cada grupo e analisados pelo teste $t$ não pareado. ${ }^{* *}(p<0,01)$, $* * *(p<0,001)$ indica diferenças significativas em relação ao grupo Sham. 


\subsection{Avaliação da expressão gênica de óxido nítrico sintase}

Na Figura 25A, observa-se a expressão gênica relativa da enzima iNOS em amostras de glândula submandibular após 3 dias do implante da ligadura. A indução da doença aumentou a expressão gênica de iNOS nos animais com periodontite em relação aos animais Sham $(1 \pm 0,002$ vs. $1,11 \pm 0,03, p<0,01)$. Na Figura 25B observamos que a indução da doença não alterou a expressão gênica de eNOS nas amostras dos animais com periodontite em relação às amostras dos animais Sham $(1 \pm 0,002$ vs. $1,02 \pm 0,037) 0,4822$. A Figura $25 \mathrm{C}$ mostra a expressão gênica relativa da enzima nNOS em amostras de glândula submandibular após 3 dias do implante da ligadura. A indução da doença aumentou a expressão gênica de nNOS em amostras de animais periodontite em relação às amostras dos animais Sham $(1 \pm 0,002$ vs. $1,09 \pm 0,023, p<0,01)$

Na Figura 26A, observa-se a expressão gênica relativa da enzima iNOS em amostras de glândula submandibular após 7 dias do implante da ligadura. A indução da doença aumentou a expressão gênica de iNOS nos animais com periodontite em relação aos animais Sham $(1 \pm 0,002$ vs. $1,2 \pm 0,036, p<0,01)$. Na Figura $26 \mathrm{~B}$ observamos que a indução da doença não alterou a expressão gênica de eNOS nos animais periodontite com relação aos animais Sham $(1 \pm 0,002$ vs. $1.117 \pm 0,02$.) Na Figura $26 \mathrm{C}$ mostra a expressão gênica relativa da enzima nNOS em amostras de glândula submandibular após 3 dias do implante da ligadura. A indução da doença aumentou a expressão gênica de nNOS nas amostras dos animais com periodontite em relação às amostras dos animais Sham $(1 \pm 0,002$ vs. $0,98 \pm 0,03, p<0,01)$

Na Figura 27A, observa-se a expressão gênica relativa da enzima iNOS em amostras de glândula submandibular após 14 dias do implante da ligadura. A indução da doença aumentou a expressão gênica de iNOS nos animais com periodontite em relação aos animais Sham $(1 \pm 0,002$ vs. $0,99 \pm 0,008)$. Na Figura $27 \mathrm{~B}$, observamos que a indução da doença não alterou a expressão gênica de eNOS nas amostras dos animais com periodontite em relação às amostras dos animais Sham $(1 \pm 0,002$ vs. $0,96 \pm 0,02)$. A Figura $27 \mathrm{C}$ mostra a expressão gênica relativa da enzima nNOS em amostras de glândula submandibular após 3 dias do implante da ligadura. A indução da doença aumentou a expressão gênica de nNOS nos

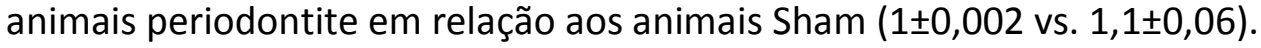



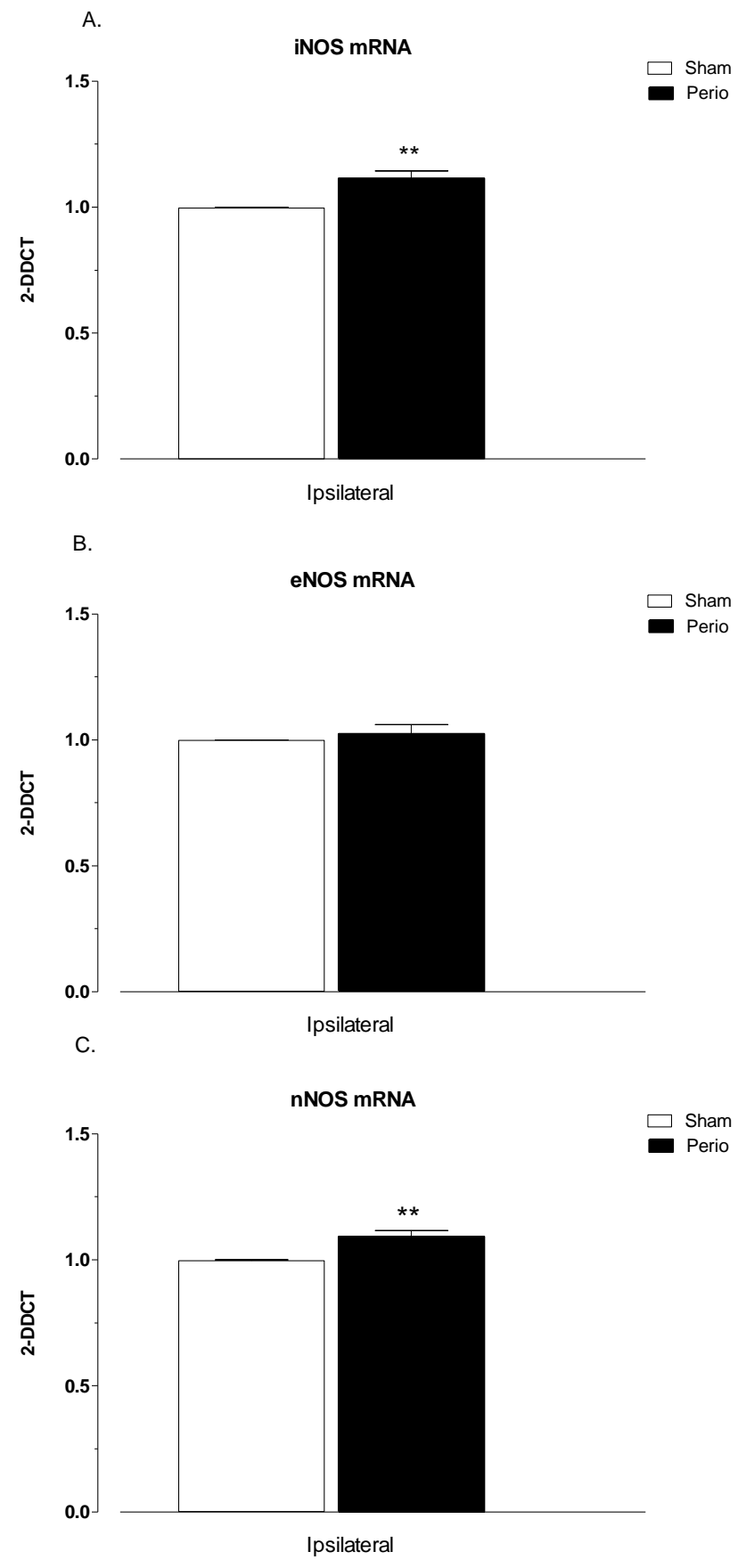

Figura 25. Análise de PCR quantitativo para as diferentes isoformas de NOS em glândula submandibular (GSM). Amostras obtidas após 3 dias da indução da doença periodontal ou procedimento simulado ( $n=3-4)$. Efeito da periodontite sobre a expressão gênica de iNOS (Painel A), eNOS(Painel B) e nNOS(Painel C). Os dados foram plotados como médiatEPM para cada grupo e analisados pelo teste $t$ não pareado. ${ }^{* *}(p<0,01)$, indica diferenças significativas em relação ao grupo Sham. 


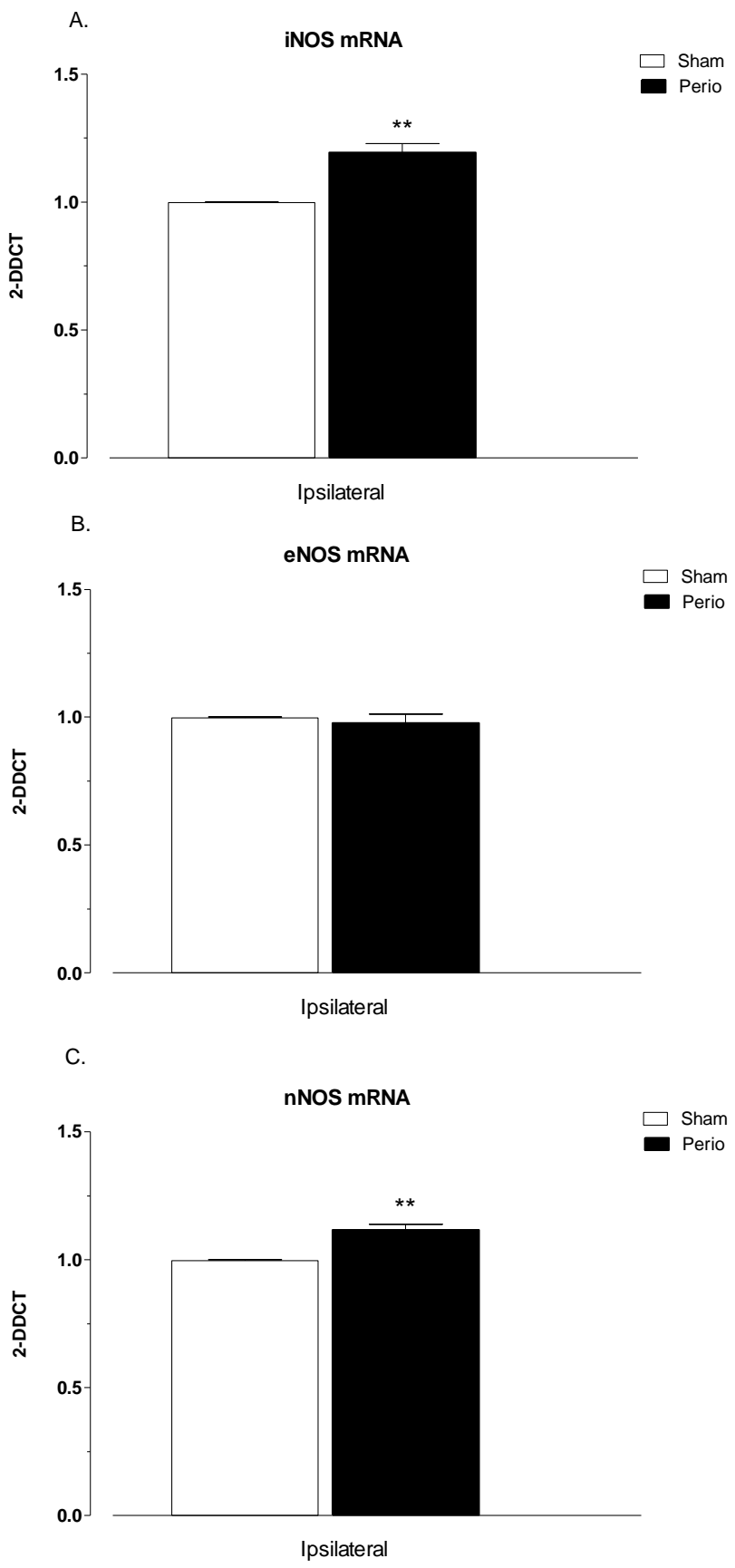

Figura 26. Análise de PCR quantitativo para as diferentes isoformas de NOS em glândula submandibular (GSM). Amostras obtidas após 7 dias da indução da doença periodontal ou procedimento simulado ( $n=3-4)$. Efeito da periodontite sobre a expressão gênica de iNOS (Painel A), eNOS(Painel B) e nNOS(Painel C). Os dados foram plotados como média土EPM para cada grupo e analisados pelo teste $t$ não pareado. ${ }^{* *}(p<0,01)$, indica diferenças significativas em relação ao grupo Sham. 
A

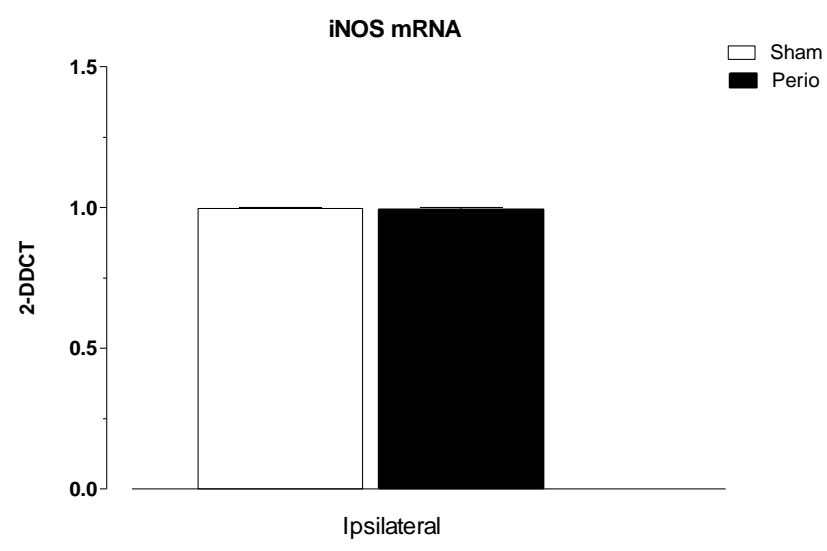

B.

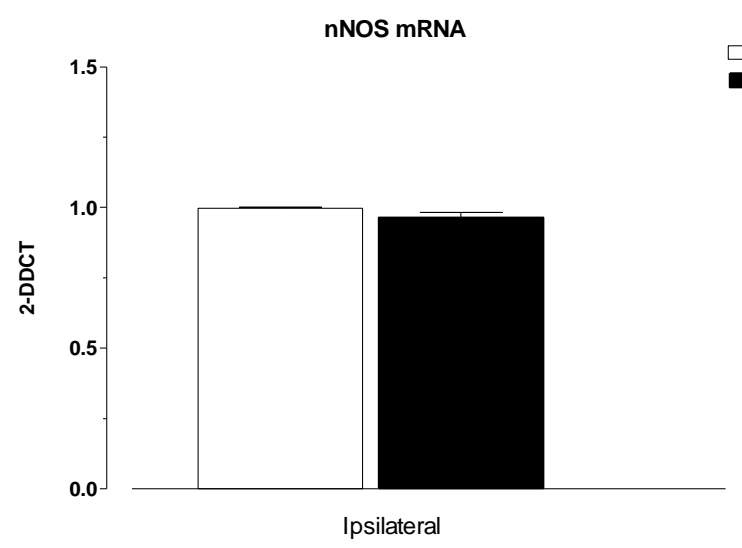

c.

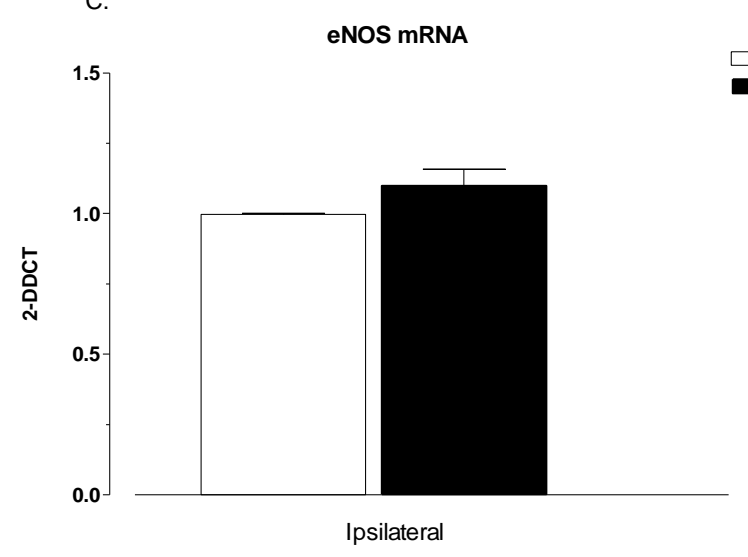


5 DISCUSSÃO

A doença periodontal, enfermidade que afeta os tecidos de suporte e sustentação dos dentes presente em grande parte na população adulta, vem sendo relacionada a alterações da saúde sistêmica dos indivíduos.

Uma possível correlação entre o grau de afecção da doença periodontal e marcadores salivares (imunoglobulinas, cálcio, cortisol entre outros) (Kaufman e Lamster, 2000) vem sendo estudada de modo a facilitar o diagnóstico da doença, o qual ainda é basicamente clínico e radiológico. Entretanto, não se sabe ao certo, até que ponto estes marcadores são provenientes das glândulas salivares, pois na cavidade bucal a saliva total mistura-se com fluido crevicular presente no sulco gengival e na bolsa periodontal, secreções brônquicas, soro e células sanquíneas provenientes de feridas orais, bem como bactérias e produtos bacterianos e células epiteliais descamadas (Mandel e Wotman, 1976; Sreebny, 1989; FDI, 1992).

O modelo de indução de doença periodontal em ratos através do implante de ligadura há bastante tempo vem sendo empregado. Sua escolha deve-se ao baixo custo, à facilidade de manipulação e, principalmente, às semelhanças biológicas com os tecidos humanos (Rovin et al., 1966). A ligadura causa um maior acúmulo de placa e ulceração do epitélio sulcular, facilitando a invasão do tecido conjuntivo por bactérias. No rato, a perda de aderência e perda óssea ocorrem em um período de sete dias (Nowotny e Sanavi, 1983; Lohinai et al., 1988; Bezerra et al., 2000, 2002; Herrera, 2011). Assim como ocorre em humanos a perda de osso alveolar é dependente de bactérias, fato comprovado por estudos nos quais a colocação da ligadura não induziu significante inflamação ou perda óssea periodontal, quando da utilização de ratos gnobióticos (Rovin et al., 1966). Outros estudos em animais, nos quais a administração tópica de clorexidina ou antibióticos via oral reduziu a reabsorção óssea e a perda de aderência, reforçam a idéia de que as bactérias desempenham um importante papel na destruição tecidual (Weiner et al., 1979; Kenworthy e Baverel, 1981).

Em nosso estudo, observamos que, três dias após a indução de doença periodontal através de implante de ligadura, há aumento da taxa de salivação estimulada por pilocarpina, não havendo, porém diferenças na taxa de salivação basal. 
O aumento na taxa de salivação poderia ser explicado pela presença do fio de algodão ao longo do sulco gengival, o que poderia estimular os mecanorreceptores presentes no periodonto, e também envolvidos na estimulação do fluxo salivar, principalmente parotídeo (Anderson e Hector, 1987; Hector e Linden, 1987).

As terminações nervosas do periodonto são divididas em dois tipos: terminações livres nociceptivas e terminais mecanorreceptores especializados (Byers, 1985; Sato et al., 1988; Maeda et al., 1989), dentre os quais as terminações de Ruffini são os principais componentes (Maeda et al., 1999). Esses receptores respondem a pequenas alterações de pressão, provocadas pelas forças mastigatórias, menos de de $5 \%$ da força mastigatória comum, já é suficiente para sua estimulação (Trulsson, 2006).As terminações de Ruffini possuem certo grau de plasticidade, com grande poder de regeneração, considerando que de três a cinco dias após uma grande movimentação ortodôntica, há regeneração desses mecanorreceptores, e catorze dias após, essas terminações nervosas já voltam a sua condição normal (Maeda et al., 1999). As informações recebidas pelos neurônios aferentes dos mecanorreceptores, assim como ocorre com as informações geradas pelas papilas gustativas, geram impulsos nervosos enviados ao núcleo salivatório parassimpático, localizado na medula oblonga. Desse centro, emergem fibras nervosas eferentes parassimpáticas, sendo a integração dos impulsos nervosos do centro salivatório para a glândula mediada pelo sistema nervoso central (Proctor e Carpenter, 2007).

Os receptores gengivais podem ter grande importância no mecanismo de salivação, apesar da mastigação de um objeto não estimular as papilas gustativas, é capaz de gerar uma resposta secretora, na qual a glândula parótida é de primordial importância (Scott, 1999). A presença da ligadura estaria causando uma estimulação constante dos mecanorreceptores e conseqüentemente da glândula parótida.

A ativação contínua dos receptores pode fazer com que seja gerado um certo grau de desensibilização dos receptores, que quando do emprego do agonista muscarínico pilocarpina suplantaria essa inibição, fazendo com que observe-se diferenças somente quando da salivação estimulada.

Em seu estado fisiológico esta glândula é responsável por um fluxo salivar intermitente, sua estimulação constante, direta e ininterrupta, poderia gerar um pequeno processo inflamatório, aumentando o grau de peroxidação lipídica dessa glândula.Um 
excesso de radicais livres envolvidos na sinalização intercelular excesso de mediadores, como o NO, também poderia ser responsável por essa lipoperoxidação glandular, a tendêndia observada na atividade da enzima óxido nítrico sintase cálcio depedente, bem como o aumento da expressão gênica de nNOS corroboram tal fato.Não foram observadas diferenças com relação ao TBARS nem em glândula submandibular, nem em amostras de saliva e soro dos animais. A peroxidase salivar/mieloperoxidase também não se encontrava aumentada.

O fato de a produção de proteínas, bem como da secreção de amilase, estarem aumentadas três dias após a colocação do fio, mas sua concentração salivar ser semelhante entre os grupos, poderia também estar vinculada à uma maior estimulação parassimpática, com conseqüente liberação de proteínas dos estoques intracelulares mais agilizada. Ao verificar as bandas específicas através de eletroforese, nota-se uma das bandas (de aproximadamente $18 \mathrm{KDa}$ ) apresenta forte tendência de aumento na saliva de animais com periodontite. Essa banda poderia corresponder à chamada proteína de translocação, encontrada em ductos e células acinares de glândulas submandibulares. Um possível papel dessa proteína na liberação de íons $\mathrm{K}^{+}, \mathrm{Na}^{+}, \mathrm{Cl}^{-}$e conteúdo protéico da saliva vem sendo estudado (Ostuni, 2008). Há também aumento da liberação, in vitro, de amilase nas amostras de GSM de animais que sofreram o implante de ligadura, em relação ao seu grupo controle, aumento foi observado nas amostras de glândula contralateral à realização do procedimento, sugerindo que a periodontite poderia ter algum efeito na atuação da glândula contralateral com relação à amilase.

O cálcio, eletrólito de bastante importância na saliva, estava aumentado, tanto em sua concentração, quanto em sua secreção. O cálcio tem sua secreção dependente do fluxo salivar e atua nos processos de remineralização do esmalte do dente (Thylstrup, 2001). Esse aumento de cálcio salivar, possivelmente está associado ao aumento de fluxo salivar, mas também poderia ser decorrente de uma tentativa do organismo de aumentar o $\mathrm{pH}$ na bolsa, diminuído devido à inflamação gerada pela presença de bactérias.

Não foi observada perda óssea; entretanto, macroscopicamente, observa-se que a região encontra-se edemaciada, evidenciando a ocorrência de um processo inflamatório, localizado nos tecidos de proteção dos dentes (gengivite). Os efeitos observados quanto à taxa de salivação poderiam ser secundários à essa gengivite induzida. A manutenção da 
ligadura durante três dias ocasionou uma inflamação nos tecidos de proteção dos dentes, processo geralmente associado a aumento de PMNs, e geração de exsudato inflamatório e dor (Zoellner et al., 2002), respostas que também poderiam influenciar a salivação.

No sétimo dia após o implante da ligadura, a taxa de salivação dos animais com periodontite encontra-se diminuída. Ao contrário do que ocorreria aos três dias, os mecanorreceptores não desempenhariam um papel estimulatório sob as glândulas, fato devido tanto por causa do remodelamento dos mecanorreceptores que sofreram grande estimulação, mas principalmente por causa da migração apical dos tecidos periodontais, gerados pela perda óssea presente no período, que os manteria afastados do fio. A diminuição da taxa, aos sete dias, é acompanhada pela diminuição da concentração e secreção salivares do íon cálcio e também pela concentração total de proteínas.

Tal fato nos levar a considerar que, assim como ocorreria no processo de maturação da placa no homem, bactérias Gram negativas estariam aderindo-se à película dental. Como decorrência disso ocorreria um aumento no LPS, que ativaria os receptores do tipo Toll-like, os quais ativariam a via do NF-KB, liberando citocinas que atingiriam a corrente sanguínea, gerando também um aumento de prostaglandina circulante.

A ativação dos receptores Toll-like, bem como aumento de prostaglandina poderia estar relacionado à diminuição do fluxo salivar, tanto estimulado, quanto não estimulado por pilocarpina, nos animais do grupo periodontite com relação aos animais do grupo Sham. Achado que está de acordo com estudo de Lomnicz et al. (1997), no qual foi gerado aumento de prostaglandinas,bem como diminuição da taxa de salivação após a administração intraperitoneal de LPS.

Essa ativação pode gerar citocinas que podem desencadear, ou aumentar respostas inflamatórias que gerariam espécies ativadas derivadas do oxigênio (como o radical hidroxila), que promove a formação de peróxidos orgânicos intermediários resultantes da ação sobre ácidos graxos insaturados (peroxidação lipídica). Tal fato explicaria o aumento de peroxidação lipídica que ocorre no plasma dos animais com periodontite, após sete dias de doença, refletindo-se nas salivas desses animais. Estudos mostram alterações no sangue de ratos com doença periodontal, como por exemplo, diminuição da glutationa redutase, glutationa oxidase e superóxido dismutase (Sobaniec et al., 2000). 
Em estudos in vitro de GSM, o IFN- $\gamma$ foi capaz de estimular a produção de NO, que regula a secreção de amilase, que, efeito potencializado pela adição de carbacol, sugerindo a ocorrência de cross-talk entre citocinas e neurotransmissores. (Español, 2001).

Na saliva dos animais sete dias após a indução observamos um aumento da atividade da mieloperoxidase/peroxidases salivares no grupo periodontite quando comparado ao grupo Sham. A presença de peroxidases (peroxidase salivar e mieloperoxidase) é de grande importância para capacidade antioxidante desse fluido. Além de possuírem ação bacteriostática, transformando o íon tiocianato em hipotiocianato (e o correspondente ácido hipotiociânico em ácido hipotiocianóico), os quais inibem o crescimento bacteriano, tem a capacidade de atuar sobre a $\mathrm{H}_{2} \mathrm{O}_{2}$ abolindo sua toxicidade (Ihalin, 2006). Entretanto o mesmo não ocorre para atividade presente em amostras de glândulas submandibular e parótidas, o que nos leva a pensar que o aumento da atividade da mieloperoxidase/peroxidases salivares possui origem distinta, conforme a progressão da doença, aos sete dias, poderia haver participação do fluido crevicular, ou até mesmo do plasma.

$O$ aumento da produção de peroxidase salivar, com a prostaglandina E2 (PGE $)$ produzida em resposta à inflamação, na tentativa de prevenir danos maiores ao organismo, mediado por aumento de AMPc e ativação de óxido nítrico foi observado (Anesini e Ferraro, 2006).

Além disso, nossos dados sugerem que a liberação de proteínas dos estoques intracelulares pode estar mais demorada, refletido na diminuição da produção de proteínas totais nos grupo periodontite. Apesar disso, a composição salivar, em ambos os grupos, é equivalente em relação à quantidade de peptídeos que a forma, entretanto, notamos, uma tendência a estarem diminuídos os peptídeos de peso molecular ao redor de 74kDa. Essa proteína poderia corresponder à osteopontina (Opn), uma glicoproteína fosforilada ácida, presente em glândula submandibular, mas principalmente nos ductos estriados dessa glândula (Obermüller, 2006). É associada à modulação da expressão de metaloproteinases e também um papel quimiotático sobre células inflamatórias (Denhardt, 2001), sua presença pode ser associada à remodelação tecidual glandular (Gresik, 1980), relacionando-se à preservação da estrutura de suas células acinares (Obermüller, 2006). A quantidade de Opn na saliva é um reflexo do conteúdo glandular dessa proteína; a menor expressão de Opn 
estaria vinculada a modificações danosas na estrutura glandular, gerando as alterações observadas, como taxa de salivação, produção e secreção de amilase diminuídas.

O aumento ou a diminuição de determinadas proteínas, também é encontrada em humanos, quando da presença de doença periodontal. Cistatina é uma proteína de $14 \mathrm{Kda}$, cujo principal efeito é inibir a cisteína peptidase, envolvida no processo de degradação do colágeno e na reabsorção óssea, sendo provenientes dos patógenos orais, incluindo, Porphyromonas gingivalis, assim como de células inflamatórias, de osteoclastos e de fibroblastos (Curtis, 2001). Na saliva de pacientes com doença periodontal há aumento de cistatinas S e C, após tratamento periodontal, há diminuição de seus níveis (Henskens et al., 1994). Outra proteína, que se apresenta em maiores quantidades na saliva de pacientes com doença periodontal, é a lactoferrina de $76 \mathrm{Kda}$, sendo observada sua diminuição após tratamento periodontal (Jentsch, 2004). Em nossos estudos, não foram observadas diferenças com relação a essas proteínas, possivelmente, devido a diferenças na microbiota dos ratos, com relação aos humanos.

Assim como a composição da saliva, os íons cálcio não estavam alterados, tanto com relação sua secreção, quanto com relação à sua produção.

Após catorze dias após da indução da doença periodontal, o funcionamento das glândulas salivares parece já estar normalizado, ao menos no que concerne à produção de saliva. As taxas de salivação são semelhantes, tanto após o estímulo com pilocarpina, quanto a produção/ concentração de cálcio, proteínas salivares e amilase. Entretanto, apesar do funcionamento da glândula estar aparentemente normalizado, observa-se ainda um aumento no TBARS salivar.

Aos catorze dias, os valores elevados de mieloperoxidase/peroxidases, estão, provavelmente, relacionados ao aumento da peroxidase nas glândulas submandibulares, Em nosso estudo o aumento da atividade da peroxidase parece estar vinculado diretamente à atividade da peroxidase glandular, diferentemente do que ocorre aos 7 dias da indução da doença. Sendo assim, esse aumento da peroxidase da glândula submandibular, poderia estar vinculado ao retorno às taxas normais de salivação, bem como de outros parâmetros salivares. 
Podemos pensar então que as alterações funcionais decorrentes do processo inflamatório podem estar compensadas por outros mecanismos nas glândulas salivares, ou então que diferentes mecanismos de controle do processo inflamatório podem estar atuando. Especialmente, porque após catorze dias da doença, é observada uma tendência ao aumento de IL-10 em GSM (que devido ao $n$ pequeno, não se observou diferença estatística). IL-10 é uma citocina que possui papel anti-inflamatório, ativada por mediadores endógenos e exógenos como o LPS (via receptores toll-like 4) (Sabat, 2010). Além disso, há também aumento da produção de IL-13, e IL-4 após indução da doença, ambas são citocinas pleiotrópicas, produzidas por células T e por mastócitos (Nelms, 1999) e compartilham propriedades biológicas como regular a ação do INFy sob células CD41, e em monócitos e macrófagos regular respostas inflamatórias, por suprimir TNF a e IL-1 (Doherty, 1993; de Waal, 1993).

Não foram observadas alterações nas concentrações salivares de íons $\mathrm{NO}_{3}{ }^{-}+\mathrm{NO}_{2}{ }^{-}$ $\left(\mathrm{NO}_{\mathrm{x}}{ }^{-}\right)$em decorrência da implantação de ligadura aos três e aos sete dias após a indução da doença. Já aos catorze dias observamos um aumento das concentrações salivares de $\mathrm{NO}_{\mathrm{x}}{ }^{-}$. Neste ponto, vale destacar os cuidados extremos que foram tomados em relação às coletas das amostras, assim como no controle da ingestão de nitratos exógenos (uma vez que os animais foram mantidos em jejum, isolados das próprias excretas e bebendo água destilada) durante as $12 \mathrm{~h}$ prévias aos procedimentos. Interessante que, apesar de observarmos maiores concentrações dos produtos finais de oxidação de $\mathrm{NO}, \mathrm{NO}_{2}{ }^{-}$e $\mathrm{NO}_{3}{ }^{-}$(medidos como $\mathrm{NO}_{\mathrm{x}}{ }^{-}$) em saliva, a atividade de NOS dependente de cálcio está diminuída nos animais perio em relação aos animais Sham (em GSM), e não foi observada alteração quanto à expressão gênica de suas isoformas. Provavelmente há algum mecanismo intraglandular regulando a atividade da óxido nítrico sintase. Em pacientes com doenças periodontais foi detectado aumento da atividade salivar de arginase, a qual compete com as NOS pela L-arginina como substrato (Özmeriç et al., 2000); da mesma forma, quantidades relativamente grandes de arginase foram detectadas em glândulas salivares de rato (Yasuda et al., 2004). Estes dados poderiam justificar a diminuição da atividade de iNOS, através do controle da metabolização da L-arginina pela arginase ao invés da NOS. 
O óxido nítrico desempenha importante papel nos mecanismos de sinalização intra e extracelular com implicações tanto fisiológicas quanto patológicas. Dentre as primeiras, a regulação da pressão arterial e do fluxo sanguíneo é uma das principais ações do óxido nítrico produzido pela enzima óxido nítrico sintase endotelial (eNOS) encontrada nos vasos (Looms et al., 2002). A óxido nítrico sintase do tipo neuronal (nNOS) é expressa em fibras nervosas que rodeiam os ácinos das glândulas parótidas e submandibulares de muitas espécies de mamíferos, incluindo os ratos (Looms et al., 2002).

Assim, o NO pode influenciar a salivação garantindo um adequado suprimento sanguíneo durante as secreções longas, exercendo efeitos regulatórios (inibitórios e excitatórios) sobre a liberação de neurotransmissores pelos neurônios periacinares, regulando o crescimento e a diferenciação das células vasculares nos tecidos ao redor da glândula, e/ou participando do sistema de defesa do hospedeiro dependendo do seu grau de produção. Por exemplo, macrófagos e neutrófilos ativados produzem elevadas quantidades de NO (de efeito citotóxico) durante a resposta imune não específica contra microorganismos (Looms et al., 2002).

O trabalho de Xia et al. (2003) mostra que a ablação bilateral das glândulas parótidas em porcos resulta em queda pronunciada do fluxo salivar paralelo à concentração do íon nitrato salivar em comparação aos animais controle, sem diferenças quanto às concentrações séricas e/ou excreção urinária deste íon. Entretanto, em condições de sobrecarga de nitrato, os autores observaram que os animais com ablação das parótidas apresentavam maiores concentrações séricas (e conseqüentemente excreção urinária aumentada) em comparação aos animais controle, assim como diminuição das concentrações salivares de nitrato, mostrando claramente a importância da funcionalidade das glândulas salivares no controle das concentrações sistêmicas de nitrato

Quanto à presença de resíduos protéicos de nitrotirosina nas glândulas submandibulares, o aumento observado na quantidade de proteínas nitradas no grupo periodontite esteja relacionado à ação da mieloperoxidase/peroxidases. As peroxidases oxidam o íon nitrito a $\mathrm{NO}^{2 \bullet}$, e resíduos de tirosina ao radical tirosila, a recombinação desses radicais produz a 3-NT.

Podemos propor três possíveis vias que seriam capazaes de gerar tais alterações: a circulação sanguínea, a circulação linfática e a inervação. Os nervos que seguem para as glândulas salivares submandibulares e parótidas passam pelo gânglio trigeminal, o mesmo 
gânglio de onde saem as inervações que vão para cavidade bucal como um todo, inclusive para o periodonto (Garret et al., 1992). Talvez por esse fato, as respostas geradas no periodonto poderiam sim afetar a resposta nas glândulas salivares. Especialmente podemos pensar nessa possibilidade, respaldando-nos em publicações recentes que relacionam a alteração da expressão de peptídeos nos gânglios trigeminais de ratos com a doença periodontal, de maneira ipsilateral à indução da doença (Gaspersic, 2008).

As alterações linfáticas poderiam ocorrer de maneira semelhante à proposta por Cavriani e colaboradores (2006), ao realizar estudo em ratos, realizando-se isquemia e reperfusão intestinal demonstraram que grande parte da resposta gerada por essa doença em órgãos periféricos, como o pulmão, por exemplo, era bastante diminuída quando a cadeia linfática que conectava os tecidos era removida, sugerindo que essa resposta era então dependente da drenagem de substâncias inflamatórias da região intraperitoneal para o pulmão. Essa possibilidade é devida, principalmente, à proximidade das glândulas submandibular/sublingual com a cadeia linfática cervical.

As alterações poderiam também ser provenientes do sistema circulatório, como já mencionado anteriormente, há estudos que correlacionam o implante da ligadura em ratos a um maior conteúdo de TBARS em sangue (Sobaniec et al., 2000).

As nossas observações demonstram que o desenvolvimento da doença periodontal pode alterar o funcionamento das glândulas salivares, variando conforme o período do implante da ligadura. Considerando o modelo animal utilizado no presente estudo a doença periodontal evolui para o estabelecimento de uma periodontite passando por uma gengivite, podemos especular que os possíveis efeitos da doença sobre as glândulas salivares e a salivação sigam padrão semelhante em humanos, exceção feita para o fato da periodontite presente neste modelo ser mais branda do que a observada em humanos, onde geralmente o número de elementos dentários afetados é maior do que um. 


\section{CONCLUSÃO}

Podemos concluir que em nosso modelo experimental há alterações em glândulas salivares, nas fases mais inicias da doença.

A fase tardia do modelo reproduziria o que ocorre na doença periodontal em humanos.

\subsection{Sugestões de mecanismos}

Com base nos resultados aqui expostos podemos concluir que:

- a indução da doença periodontal nos animais aos três dias foi capaz de estimular a atividade das glândulas salivares, com aumento do fluxo salivar estimulado; provavelmente essa ação deve-se a uma estimulação maior do sistema simpático/parassimpático nas glândulas, não foi observada perda óssea;

- aos sete dias é observada diminuição do funcionamento glandular; provavelmente essa ação deve-se a uma inibição das respostas glandulares ao sistema simpático/parassimpático e há presença de perda óssea;

- aos catorze dias, há um retorno aos padrões de normalidade da glândula, provavelmente pela ação de citocinas que desempenham papel anti-inflamatório; entretanto perda óssea está presente. 


\section{REFERÊNCIAS*}

Albandar JM, Rams TE. Global epidemiology of periodontal diseases: an overview. Periodontol 2000. 2002;29:7-10.

Allaker RP, Silva Mendez LS, Hardie JM, Benjamin N. Antimicrobial effect of acidified nitrite on periodontal bacteria. Oral Microbiol Immunol. 2001;16:253-6.

Almståhl A, Wikström M, Groenink J. Lactoferrin, amylase and mucin MUC5B and their relation to the oral microflora in hyposalivation of different origins. Oral Microbiol Immunol. 2001;16:345-52.

Alugupalli KR, Kalfas S, Edwardsson S, Naidu AS. Lactoferrin interaction with Actinobacillus actinomycetemcomitans. Oral Microbiology and Immunology. 1995;10:35-41.

Amano A, Kataoka K, Raj PA, Genco RJ, Shizukuishi S. Binding sites of salivary statherin for Porphyromonas gingivalis recombinant fimbrillin. Infect. Immun. 1996;64:4249-54.

Anderson DJ, Hector MP. Periodontal Mechanoreceptors and Parotid Secretion in Animals and Man. J Dent Res. 1987;66:518-23.

Anesini C, Ferraro G. Peroxidase secretion in rat submandibular glands induced by PGE2: Role of cAMP and nitric oxide. Prostaglandins, Leukotrienes and Essential Fatty Acids. 2006;74:303-8.

Armitage GC. Developmente of a classification system for periodontal diseases and conditions. Am Periodontol. 1999;4:1-6.

Arnold RR, Cole MF, McGhee JR. A bactericidal effect for human lactoferrin. Science 1977;197:263-265.

Augusto O. Radicais livres: bons, maus e naturais. São Paulo: Oficina de Textos; 2006. 120 p.

Auer A, Aleksic J,Ivic-Kardum M, Auer J, Culo F. Nitric oxide synthesis is decreased in periodontitis. J. Clin. Periodontol. 2001;28:6:565-8.

Ayad M. The association of basic proline-rich peptides from human parotid gland secretions with caries experience. J Dent Res. 2000;79:976-82.

*De acordo com:

ASSOCIAÇÃO BRASILEIRA DE NORMAS TÉCNICAS. NBR 6023: informação e documentação: referências: elaboração. Rio de Janeiro, 2002. 
Barreto RL, Correia CR, Muscará MN, Óxido Nítrico: Propriedades e potenciais usos terapêuticos.Quim. Nova.2005;28:6:1046-54.

Beck J, Garcia R, Heiss G, Vokonas PS, Offenbacher S. Periodontal disease and cardiovascular disease. J Periodontol. 1996;67:1123-37.

Beck, JD, Slade G, Offenbacher S. Oral disease, cardiovascular disease and systemic inflammation. Periodontology. 2000;23:110-20.

Beckman JS. Oxidative damage and tyrosine nitration from peroxynitrite. Chem ResToxicol. 1996; 9:836-44.

Beckman JS, Koppenol WH. Nitric oxide, superoxide, and peroxynitrite: the good,the bad, and ugly. Am J Physiol. 1996; 271:1424-37.

Bezerra MM, Brito GA, Ribeiro RA, Rocha FA. Low-dose doxycycline prevents inflammatory bone resorption in rats. Braz J Med Biol Res. 2002;35:613-6.

Bezerra MM, de Lima V, Alencar VB, Vieira IB, Brito GA, Ribeiro RA, Rocha FA. Selective cyclooxygenase-2 inhibition prevents alveolar bone loss in experimental periodontitis in rats. JPeriodontol. 2000;71:1009-14.

Bird RP, Draper AH. Comparative studies on different methods of malondyaldehyde determination. Meth Enzymol. 1984;90:105-10.

Boo YC, Sorescu GP, Bauer PM, Fulton D, Kemp BE, Harrison DG, Sessa WC, Jo H. Endothelial NO synthase phosphorylated at SER635 produces NO without requiring intracellular calcium increase. Free Radic Biol Med. 2003;35:729-41.

Bose R, Sutherland GR, Pinsky C. Biological and methodological implications of prostaglandin involvement in mouse brain lipid peroxidation measurements. Neurochem Res. 1989; $14: 217-220$.

Bradford, M. A rapid and sensitive method for the quantitation of microgram quantities of protein utilizing the principle of protein-dye binding. Anal Biochem. 1976;7:248-54.

Bradley PP, Priebat DA, Christensen RD, Rothstein G. Measurement of cutaneous inflamation: Estimulation of neutrophil content with an enzyme marked. J Invest Dermatol. 1982; 78:206-9.

Brasil. Ministério da Saúde. Secretaria de Atenção à Saúde. Departamento de Atenção Básica. Projeto SB Brasil 2003: condições de saúde bucal da população brasileira 20022003:resultados principais. Brasília: Ministério da Saúde; 2005. 
Bredt DS, Glatt CE, Hwang PM, Fotuhi M, Dawson TM, Snyder SH. Nitric oxide synthase protein and mRNA are discretely localized in neuronal populations of the mammalian CNS together with NADPH diaphorase. Neuron. 1991; 7:615-24.

Breivik T, Gundersen Y, Opstad PK, Fonnum F. Chemical sympathectomy inhibits periodontal disease in Fischer 344 rats. J Periodont Res 2005; 40: 325-330.

Breivik T, Gundersen Y, Myhrer T, Fonnum F, Osmundsen H, Murison R, Gjermo P, von Hörsten S, Opstad PK. Enhanced susceptibility to periodontitis in an animal model of depression: reversed by chronic treatment with the anti-depressant tianeptine. J Clin Periodontol. 2006.33:469-77.

Byers, M.R., 1985. Sensory innervation of periodontal ligament of rat molars consists of unencapsulated Ruffini-like mechanoreceptors and free nerve endings. J. Comp. Neurol. 231, 500-518.

Brown I, Loe H. Prevalence, extent, severity and progression of periodontal disease. Periodontology 2000. 1993;2:57-71.

Buhlin K, Hultin M, Norderyd O, Persson L, Pockley AG, Rabe P, Klinge B, Gustafsson A. Risk factors for atherosclerosis in cases with severe periodontitis. J Clin Periodontol. 2009;7:5419.

Busch L, Sterin-Borda L, Borda E. $\beta$-Adrenoceptor alterations coupled with secretory response and experimental periodontitis in rat submandibular glands. Archieves of oral biology. 2008;53:509-16.

Carossa S, Pera P, Doglio P, Lombardo S, Colagrande P, Brussino L., Rolla G, Bucca C. Oral nitric oxide during plaque deposition. Eur J Clin Investigation. 2001;31:876-9.

Carranza FA, Newman MG. Em: Periodontia Clínica. 9 $9^{\mathrm{a}}$ ed. Guanabara Koogan: Rio de Janeiro; 2002.

Carlson GW. The salivary glands. Embryology, anatomy, and surgical applications. Surg Clin North Am. 2000;80:261-73.

Cavriani G, Domingos HV, Oliveira-Filho RM, Sudo-Hayashi LS, Vargaftig BB, de Lima WT. Lymphatic thoracic duct ligation modulates the serum levels of IL-1beta and IL-10 after intestinal ischemia/reperfusion in rats with the involvement of tumor necrosis factor alpha and nitric oxide. Shock. 2007;27:209-13.

Curtis MA, Aduse-Opoku J, Rangarajan M. Cysteine proteases of Porphyromonas gingivalis.Crit Rev Oral Biol Med. 2001;3:192-216. 
D'Aiuto F, Nibali L, Mohamed-Ali V, Vallance P, Tonetti MS. Periodontal therapy: a novel nondrug-induced experimental model to study human inflammation. J Periodontal Res. 2004;39:294-99.

Dale AC. Glândulas salivares. In: Ten Cate R, editor. Histologia bucal: desenvolvimento, estrutura e função. 5a ed. Rio de Janeiro: Guanabara Koogan; 2001. p.439.

Dawson DA. Nitric oxide and focal cerebral ischemia: multiplicity of actions and diverse outcome. Cerebrovasc Brain Metab Rev. 1994;6:4:299-324.

De Lorenzo JL. Biofilme dental, in: Microbiologia para estudante de Odontologia. Atheneu, São Paulo. 2004;73-85.

Denhardt DT, Noda M, O'Regan AW, Pavlin D, Bernan JS. Osteopontin as a means to cope with environmental insults: regulation of inflammation, tissue remodeling, and cell survival. J Clin Invest. 2001;107:1055-61

de Pablo P, Chapple IL, Buckley CD, Dietrich T. Periodontitis in systemic rheumatic diseases. Nat Rev Rheumatol. 2009;4:218-24.

de Waal Malefyt R, Figdor C, Huijbens R, Mohan-Peterson S, Bennett B,Culpepper J, Dang W, Zurawski G, de Vries J. Effects of IL-13 on phenotype, cytokine production, and cytokine function, on human monocytes. J Immunol. 1993; 151:6370-81.

Dery RE, Mathison R, Davison J, Befus AD. Inhibition of allergic inflammation by C-terminal peptides of the prohormone submandibular rat 1 (SMR-1)-1).Int Arch Allergy Immunol. 2001;124:201-4.

Di Paola R, Marzocco S, Dattola F, Rotondo F, Britti D, De Majo M, Genovese T,Cuzzocrea S. Effect of aminoguanidine in ligature-induced periodontitis in rats. J. Dent. Res.2004;83: 4:343-8.

Dixon DR, Bainbridge BW, Darveau RP. Modulation of the innate immune response within the periodontium. Periodontol 2000. 2004;35:53-74.

Doherty M, Kastelein K, Menon S, Andrade SRC. Modulation of murine macrophage function by IL-13. J Immunol. 1993; 151:7151-60.

Español AJ, Sales ME. Parasympathetic modulation of amylase secretion by IFNg in murine submandibular glands. Int Immunopharmacol. 2001; 5:903-10

Eiserich, JP, Butler J, van der Vliet A, Cross CE, Halliwell B. Nitric oxide rapidly scavengestyrosine and tryptophan radicals. Biochem J. 1995; 310:745-9. 
Fialho de Araújo AM, Oliveira-Filho RM, Trezena AG, Borelli P, Mathison RD, Tavares de Lima W. Role of submandibular salivary glands in LPS-induced lung inflammation in rats Neuroimmunomodulation. 2002;10:73-9.

FDI Working Group 10, Core. Saliva: its role in health and disease. International Dental Journal. 1992; 42: 291-304.

Feelisch M. Biotransformation to nitric oxide of organic nitrates in comparison to other nitrovasodilators. Eur. Heart J. 1993;14:123-32.

Ford PJ, Gamonal J, Seymour GJ. Immunological differences and similarities between chronic periodontitis and aggressive periodontitis. . Periodontology 2000. 2010;53:111-23.

Gaspersic R, Kovacic U, Cör A, Skaleric U. Unilateral ligature-induced periodontitis influences the expression of neuropeptides in the ipsilateral and contralateral trigeminal ganglion in rats. Arch Oral Biol. 2008;53:659-65.

Gatti RM, Radi R, Augusto O. Peroxynitrite-mediated oxidation of albumin to the proteinthiyl free radical. FEBS Lett. 1994; 18:348:287-90.

Gibbons RJ, Hay DI. Human salivary acidic proline-rich proteins and statherin promote the attachment of Actinomyces viscosus LY7 to apatitic surfaces. Infect Immunol. 1988;56:43945.

Gibbons RJ. Adherent interactions which may affect microbial ecology in the mouth. J Dent Res. 1994;63:378-85.

Greengard P. Cyclic nucleotides, protein phosphorylation, and neuronal function. Adv Cyclic Nucleotide Res. 1975;5:585-601.

Gresik EW.Postnatal developmental changes in submandibular glands of rats and mice. J Histochem Cytochem. 1980; 28:860-70

Grisham MB, Jhonson GG, Gautreaux MD, Berg RD. Measurement of Nitrate and nitrite in extracellular fluids: a window to systemic nitric oxide metabolism. Met Comp Met Enzymol. 1995;7:84-90.

Halliwell B, Gutteridge JMC. Free radicals in biology and medicine. 3 ed. New York:Oxford University Press; 2007.

Heasman L, Stacey F, Preshaw PM, McCracken GI, Hepburn Sand Heasman PA, The effect of smoking on periodontal treatment response: a review of clinical evidence, J Clin Periodontol . 2006;33:241-53. 
Hector MP, Linden RWA. The possible role of periodontal mechanoreceptors in the control of parotid secretion in man. Q.J. Exp. Physiol. 1987;72:285-301.

Heitz-Mayfield LJA. Disease progression: identification of high-risk groups and individuals for periodontitis. J Clin Periondontol. 2005;32:196-209.

Henskens YM, Veerman EC, Mantel MS, van der Velden U, Nieuw Amerongen AV. Cystatins S and $C$ in human whole saliva and in glandular salivas in periodontal health and disease. J Dent Res. 1994;73:1606-14.

Herrera BS, Martins-Porto R, Campi P, Holzhausen M, Teixeira SA, Mendes GD, Costa SK, Gyurko R, Van Dyke TE, Spolidório LC, Muscará MN. Local and cardiorenal effects of periodontitis in nitric oxide-deficient hypertensive rats. Arch Oral Biol. 2011;56:41-7.

Herrera BS, Martins-Porto R, Maia-Dantas A, Campi P, Spolidorio LC, Costa SK, Van Dyke TE, Gyurko R, N Muscara M. iNOS-Derived Nitric Oxide Stimulates Osteoclast Activity and Alveolar Bone Loss in Ligature-Induced Periodontitis in Rats. J Periodontol. 2011 Mar 21. [Epub ahead of print]

Hesse M, ModolellM, La Flamme AC, Schito M, Fuentes JM, Cheever AW, Pearce EJ, Wynn TA. Differential regulation of nitric oxide synthase-2 and arginase- 1 by type 1/type 2 cytokines in vivo: granulomatous pathology is shaped by the pattern of L-arginine metabolism. J. Immunol. 2001;167:11: 6533-44.

Hibbs JB Jr. Synthesis of nitric oxide from L-arginine: a recently discovered pathway induced by cytokines with antitumour and antimicrobial activity. ResImmunol. 1991;142;7:565-9.

Hiki K, Hattori R, Kawai C, Yui Y. Purification of insoluble nitric oxide synthase from rat cerebellum. J Biochem. 1992; 111:556-558.

Ihalin R, Loimaranta V, Tenovuo J. Origin, structure, and biological activities of peroxidases in human saliva. Archives of Biochemistry and Biophysics. 2006;445:261-8.

Jentsch $H$, Sievert $Y$, Göcke R. Lactoferrin and other markers from gingival crevicular fluid and saliva before and after periodontal treatment. J Clin Periodontol. 2004;31:511-4.

Jin Y, Hak-Kong Y. Supragingival; calculus: formation and control. Crit Rev Oral Biol Med. 2002;13:426-41.

Johansson I, Bratt P, Hay DI, Schluckebier S, Stromberg N. Adhesion of Candida albicans, but not Candida krusei, to salivary statherin and mimicking host molecules. Oral Microbiol Immunol. 2000;5:112-8.

Johnson GK e Slach NA. Impact of tobacco use on periodontal status. J Dent Educ. 2001;65:313-21. 
Katchburian E, Arana V. Glândulas salivares. In: Histologia e embriologia oral. $2^{\text {a }}$ ed. Rio de Janeiro: Guanabara Koogan; 2004. p. 115-45.

Kaufman E, Lamster IB. Analysis of saliva for periodontal diagnosis--a review. J Clin Periodontol. 2000 Jul;27(7):453-65.

Kenworthy R, Baverel M. Studies of a periodontal tissue lesion in the rat, untreated or treated with chlorhexidine digluconate. J Clin Periodontol 1981;8:349-358.).

King PA, Jamison E, Strahs D, Anderson VE, Brenowitz M. 'Footprinting' proteins on DNA with peroxonitrous acid. Nucleic Acids Res. 1993;25;21:2473-8.

Kinane DF, Berglundh T, Lindhe J.Pathogenesis of Periodontitis. In: Lindhe J, Lang NP, Karring, editors. Clinical Periodontology and Implant Dentistry. 5th ed. Oxford: Blackwell Publishing; 2008. p. 285-99.

Kitamura K, Lian Q, Carl A, KuriayamaH. S-nitrosocysteine, but not sodium nitroprusside, produces apamin-sensitive hyperpolarization in rat gastric fundus. $\mathrm{Br} J$ Pharmacol. 1993;109:415-23.

Komeima K, Hayashi Y, Naito Y, Watanabe Y. Inhibition of neuronal nitric oxide synthase by calcium/calmodulin-dependent protein kinase Ilalpha through Ser847 phosphorylation in NG108-15 neuronal cells. J Biol Chem. 2000;275:28139-43.

Kornman K, Page RC, Tonetti MS. The host response to the microbial challenge in periodontitis: assembling the players. Periodontol 2000. 1997;14:33-53.

Laborlab. Kit de determinação de cálcio: CAT N05600. São Paulo: Laborlab2009

Lee S, Barbanel G, Rivier C. Systemic endotoxin increases steady-state gene expression of hypothalamic nitric oxide synthase: comparison with corticotropin-releasing factor and vasopressin gene transcripts. Brain Res.1995;705:136-48.

Linden GJ, Mullally BH, Freeman R. Stress and the progression of periodontal disease. J Clin Periodontol. 1996;23:675-80.

Liu CY, Lerner UH, Teng YT. Cytokine responses against periodontal infection: protective and destructive roles. Periodontology 2000. 2010;52:163-206.

Lohinai Z, Benedek P, Feher E, Gyorfi A, Rosivall L, Fazekas A, Salzman AL, Szabo C. Protective effects of mercaptoethylguanidine, a selective inhibitor of inducible nitric oxide synthase, in ligature induced periodontitis in the rat. Br J Pharmacol 1998;123:353-360

Looms D, Tritsaris K, Pedersen AM, Nauntofte B, Dissing S. Nitric oxide signalling in salivary glands. J Oral Pathol Med. 2001;31:569-84. 
Lundy FT, Linden GJ. Neuropeptides and neurogenis mechnisms in oral and periodontal inflammation. Crit Rev Oral Biol Med. 2004;15:82-98.

Maeda T, Sato , Kobayashi S, Iwanaga T, Fujita T.The ultrastructure of Ruffini endings in the periodontal ligament of rat incisors with special reference to the terminal Schwann cells (Kcells). Anat Rec. 1989; 223:95-103.

Maeda T, Ochi K, Nakakura-Ohshima K, Youn SH,Wakisaka S. The Ruffini Ending as the Primary Mechanoreceptor in the Periodontal Ligament: Its morphology Cytochemical Features, Regeneration, and Development. Crit Rev Oral Biol Med. 1999;10:307-27.

Matejka M, Partyka L, Ulm C, Solar P, Singer H. Nitric oxide is increased in periodontal disease. J. Periodontal Res. 1998;33:8:517-8.

Mathison R, Davison JS, Befus, AD. Neuroendocrine regulation of inflammation and tissue repair by submandibular gland factors. Immunol T. 1994;15:527-32.

Mathison R, Davison JS, Befus, AD. A peptide from the submandibular glands modulates inflammatory responses. Int Arch Allerg Immunol. 1997a;13:337-8.

Mathison R, Befus, AD, Davison JS. A novel submandibular gland peptide protects against endotoxic and anaplhylatic shock. Am Physiol Soc. 1997b;1017-23.

Mathison R, Lo P, Tan D, Scott B, Davison JS. The tripeptide feG reduces endotoxin-provoked perturbation of intestinal motility and inflammation. Neurogastroenterol Mot. 2001;13:599603.

Mealey BL. Diabetes and periodontal disease: two sides of a coin. Compend Contin Educ Dent. 2000; 21: 943-46.

Meurman JH, Sanz M, Janket SJ. Oral health, atherosclerosis, and cardiovascular disease. Crit Rev Oral Biol Med. 2004;15:403-13.

Nagler RM, Klein I, Zarzhevsky N, Drigues N, Reznick AZ. Characterization of the differentiated antioxidant profile of human saliva. Free Radic Biol Med. 2002;32:268-77.

Nelms K, Keegan AD, Zamorano J, Ryan JJ, Paul WE. The IL-4 receptor: Signaling mechanisms and biological functions. Ann Rev Immunol. 1999;17:701-38.

Noack B, Genco RJ, Trevisan M, Grossi S, Zambon JJ, De Nardin E. Periodontal infections contribute to elevated systemic C-reactive protein level. J Periodontol. 2001;72:1221-7.

Nowotny A, Sanavi F. Induction of nonspecific tolerance to endotoxins reduces the alveolar bone resorption in ligature-treated rats. Infect Immun 1983;39:873-878. 
Obermüller N, Gassler N, GretzN, Kranzlin B, Hoffmann S, Geiger S, Gauer, S. Distinct immunohistochemical expression of osteopontin in the adult rat major salivary glands $\mathrm{J}$ Mol Hist. 2006;37:53-60.

Ohta $\mathrm{Y}$, Kongo $\mathrm{M}$, Kishikawa T. Melatonin exerts a therapeutic effect on cholestaticliver injury in rats with bile duct ligation. J. Pineal Res. 2002;34:119-126.

Ostuni MA, Tumilasci OR, Peranzi G, Cardoso EML, Contreras LN, Arregger AL, Papadopoulos $\mathrm{V}$, Lacapere JJ.Effect of translocator protein (18 kDa)-ligand binding on neurotransmitterinduced salivary secretion in rat submandibular glands. Biol. Cell.2008;100:427-39.

Özmeriç, N., Elgün, S., Uraz, A. Salivary arginase in patients with adult periodontitis. Clin Oral Invest. 2000;4:21-4.

Page RC. The role of inflammatory mediators in the pathogenesis of periodontal disease. J Periodontal Res. 1991;26:230-42.

Page, R. Milestones in periodontal research and the remaing critical issues. J Periodont Re. 1999;34:331-9.

Page RC, Schroeder HE. Pathogenesis of Inflammatory Periodontal Disease: A Summary of Current Work. Lab Invest. 1976;34:235-49.

Palmer RM, Ashton DS, Moncada S. Vascular endothelial cells synthetize nitric oxide from Larginine. Nature. 1988;333:664-6.

Pedersen AM, Bardow A, Jensen BS, Nauntofte B. Saliva and gastrointestinal functions of taste, mastication,swallowing and digestion. Oral Diseases. 2002;8:117-29.

Peterson GL. A simplification of the protein assay method of Lowry et al. which is more generally applicable. Anal. Biochem. 1977;83:346-56.

Pinto VG. Epidemiologia das doenças bucais no Brasil. In: Kriger L. Aboprev: promoção de saúde bucal. $2^{a}$ ed. São Paulo: Artes Médicas; 1999. p. 27-42.

Proctor GB, Carpenter GH. Regulation of salivary gland function by autonomic nerves. Autonomic Neuroscience: Basic and Clinical. 2007; 133: 3-18.

Rickard AH, Gilbert P, High NJ, Kolenbrander PE, Handley PS. Bacterial coaggregation: an integral process in the development of multi-species biofilms Trends Microbiol. 2003;1:94100.

Rougeot C, Rosinski-Chupin I, Mathison R, Rougeon F. Rodent submandibular gland peptide hormones and other biologically active peptides.Peptides. 2000;21:443-55. 
Rovin S, Costich ER, Gordon HA. The influence of bacteria and irritation in the initiation of periodontal disease in germfree and conventional rats. J Periodontal Res. 1966;3:193-204.

Sabat R, Grutz G, Warszawska K, Kirsch S, Witte E, Wolk K, Geginat J. Biology of interleukin10. Cytokine \& Growth Factor Reviews.2010: 331-44.

Salinovich O, Montelano RC. Reversible staining and peptide mapping of proteins transferred to nitrocellulose after separation by sodium dodecyl sulfate-polyacrylamide gel electrophoresis. Anal. Biochem. 1986;156:341-7.

Sato O, Maeda T, Kobayashi S, Iwanaga T, Fujita T,Takahashi Y. Innervation of Periodontal ligament and dental pulp in the rat incisor: an immunohistochemical investigation of neurofilament protein and glia-specific S-100 protein. Cell Tissue Res. 1988;2511:3-21.

Scott BJJ, Bajaj J, Linden RWA. The contribution of mechanoreceptive neurones in the gingival tissues to the masticatory-parotid salivary reflex in man. Journal of Oral Rehabilitation. 1999;26:791-7

Scott JA, Mehta S, Duggan M, Bihari A, McCormack DG. Functional inhibition of constitutive nitric oxide synthase in a rat model of sepsis. Am J Respir Crit Care Med. 2002;165:1426-32.

Shibuki K, An electrochemical microprobe for detecting nitric oxide release in brain tissue. Neurosci Res. 1990;9: 69-76.

Sreebny LM. Recognition and treatment of salivary induced conditions. Int Dent J. 1989 39:197-204.

Seymour RA, Preshaw PM, Thomason JM, Ellis JS, Steele JG. Cardiovascular diseases and periodontology. J Clin Periodontol. 2003;30:279-92.

Shiboski T, Hodgson J, Ship M, Schiodt. Management of salivary hypofunction during and after radiotherapy. Oral Surgery, Oral Medicine, Oral Pathology, Oral Radiology, and Endodontology. 2007;103:1-19.

Sobaniec H, Sobaniec-üotowska ME. Morphological examinations of hard tissues of paradontium and evaluation of selected processes of lipid peroxidation in blood serum of rats in the course of experimental periodontitis. Med Sci Monit. 2000;6:875-81.

Socransky SS,.Haffajee AD. Periodontal Infections. In: Lindhe J, Lang NP, Karring T. Clinical Periodontology and Implant Dentistry. $5^{\mathrm{a}}$ Ed. Oxford: Blackwell Publishing; 2008. p.207-49.

Socransky SS, Haffajee AD. Evidence of bacterial etiology: a historical perspective. Periodontol 2000. 1994;5:7-25. 
Tanner A, Maiden MF, Macuch PJ, Murray LL, Kent RL Jr. Microbiota of health, gingivitis, and initial periodontitis. J Clin Periodontol. 1998;25:85-98.

Thylstrup A., Fejerskov O. Cariologia clínica. $3^{\text {a }}$ ed. São Paulo: Liv. Ed. Santos; 2001.

Timmerman MF, van der Weijden GA. Risk factors for periodontitis. Int J Dent Hygiene. 2006;4:2-7.

Tinoco EM, Beldi MI, Loureiro CA, Lana M, Campedelli F, Tinoco NM. Localized juvenile periodontitis and Actinobacillus actinomycetemcomitans in Brazil population. European Journal of Oral Sciences. 1997;105:9-14.

Tlaskalova-Hogenova H, Tuckova L, Lodinova-Zadnikova R, Stepankova R. Cukrowskac B, Fund DP, Striz I, Kozakova H, Trebichavsky I, Sokola D, Rehakova Z, Sinkora J, Fundova P, Horakova D, Jelınkova L, Sanchez D. Mucosal Immunity: Its Role in Defense and Allergy. Int Arch Allergy. 2002;28:77-89.

Trulsson M. Sensory-motor function of human periodontal mechanoreceptors. Journal of Oral Rehabilitation. 2006;33;262-73.

Vallance P, Leiper J. Blocking NO synthesis: how, where and why? Nature. 2002; 1:939-50.

Vettore MV, Leal M, Leão AT, da Silva AM, Lamarca GA, Sheiham A. The relationship between periodontitis and preterm low birthweight.J Dent Res. 2008;87:73-8.

ia DS, Deng DJ, Wang SL. Destruction of parotid glands affects nitrate and nitrite metabolism. J Dent Res. 2003;82:101-5.

Yasuda Y, Moriwaki S, Furuyama S. Distribution and properties of arginase in the salivary glands of four species of laboratory mammals. J comp Physiol. 2004;174:237-42.

Zappa U. Histology of the periodontal lesion: implications for diagnosis. Periodontol 2000. 1995;7:22-38.

Zoellner H, Chapple CC, Hunter N. Microvasculature in Gingivitis and Chronic Periodontitis: Disruption of Vascular Networks With Protracted Inflammation. Microscopy research and technique. 2002;56:15-31.

Weiner GS, DeMarco TJ, Bissada NF. Long term effect of systemic tetracycline administration on the severity of induced periodontitis in the rat. J Periodontol 1979;50:619-623 